\title{
Review \\ Treatment of Glaucoma with Natural Products and Their Mechanism of Action: An Update
}

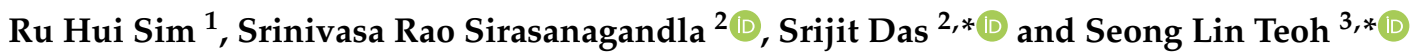 \\ 1 Tanglin Health Clinic, Kuala Lumpur 50480, Malaysia; simruhui@gmail.com \\ 2 Department of Human \& Clinical Anatomy, College of Medicine \& Health Sciences, Sultan Qaboos University, \\ Al-Khoud, Muscat 123, Oman; srinivasa@squ.edu.om \\ 3 Department of Anatomy, Faculty of Medicine, Universiti Kebangsaan Malaysia Medical Centre, Cheras, \\ Kuala Lumpur 56000, Malaysia \\ * Correspondence: s.das@squ.edu.om (S.D.); teohseonglin@ppukm.ukm.edu.my (S.L.T.)
}

Citation: Sim, R.H.; Sirasanagandla, S.R.; Das, S.; Teoh, S.L. Treatment of Glaucoma with Natural Products and Their Mechanism of Action: An Update. Nutrients 2022, 14, 534. https://doi.org/10.3390/ nu14030534

Academic Editor: Md Soriful Islam

Received: 23 December 2021

Accepted: 18 January 2022

Published: 26 January 2022

Publisher's Note: MDPI stays neutral with regard to jurisdictional claims in published maps and institutional affiliations.

Copyright: (c) 2022 by the authors. Licensee MDPI, Basel, Switzerland. This article is an open access article distributed under the terms and conditions of the Creative Commons Attribution (CC BY) license (https:// creativecommons.org/licenses/by/ $4.0 /)$.

\begin{abstract}
Glaucoma is one of the leading causes of irreversible blindness. It is generally caused by increased intraocular pressure, which results in damage of the optic nerve and retinal ganglion cells, ultimately leading to visual field dysfunction. However, even with the use of intraocular pressure-lowering eye drops, the disease still progresses in some patients. In addition to mechanical and vascular dysfunctions of the eye, oxidative stress, neuroinflammation and excitotoxicity have also been implicated in the pathogenesis of glaucoma. Hence, the use of natural products with antioxidant and anti-inflammatory properties may represent an alternative approach for glaucoma treatment. The present review highlights recent preclinical and clinical studies on various natural products shown to possess neuroprotective properties for retinal ganglion cells, which thereby may be effective in the treatment of glaucoma. Intraocular pressure can be reduced by baicalein, forskolin, marijuana, ginsenoside, resveratrol and hesperidin. Alternatively, Ginkgo biloba, Lycium barbarum, Diospyros kaki, Tripterygium wilfordii, saffron, curcumin, caffeine, anthocyanin, coenzyme Q10 and vitamins B3 and $\mathrm{D}$ have shown neuroprotective effects on retinal ganglion cells via various mechanisms, especially antioxidant, anti-inflammatory and anti-apoptosis mechanisms. Extensive studies are still required in the future to ensure natural products' efficacy and safety to serve as an alternative therapy for glaucoma.
\end{abstract}

Keywords: glaucoma; herbs; traditional medicine; retinal ganglion cells; intraocular pressure

\section{Introduction}

Glaucoma is one of the leading causes of irreversible blindness, causing $6.6 \%$ of all blindness in 2010 [1]. According to the World Health Organization's (WHO) World Report on Vision, of the estimated 2.2 billion people having a vision impairment around the world, glaucoma affects an estimated 6.9 million people [2]. It has been further estimated that by 2040, approximately 111.8 million people worldwide aged between 40 and 80 years old will be affected by glaucoma [3]. Glaucoma is generally caused by intraocular pressure (IOP, $>21 \mathrm{mmHg}$ ) build-up, resulting from blockage of intraocular fluid and aqueous humor drainage [4]. The elevated IOP progressively damages the retinal ganglion cells (RGCs) and optic nerve, causing visual field constriction that affects the peripheral field initially and the central vision field gradually [5]. Glaucoma patients require lifelong treatment and followup, and the disease has a significant negative impact on patients' quality of life in terms of anxiety, psychological well-being, daily life, driving and confidence in healthcare [6]. The main risk factors for glaucoma prevalence include age, family history with glaucoma, African American race, thinner central corneal thickness, pseudoexfoliation, pigment dispersion and myopia [7]. Additionally, an association between diabetes, hypertension, triglyceride levels and glaucoma were also identified $[7,8]$. Furthermore, genetic factors are also known to be risk factors for glaucoma, in which single-nucleotide polymorphisms in 
numerous genes (e.g., myocilin, apolipoprotein E, X-ray repair cross-complementing group 1 , zona pellucida glycoprotein 4 ) have been shown to be associated with an increased risk of glaucoma $[9,10]$.

Glaucoma can be classified into two major types, i.e., open-angle (OAG) and angleclosure glaucoma (ACG), according to the physical obstruction of the aqueous humor drainage system, and the appearance of the iridocorneal angle and trabecular meshwork (TM) [11]. Alternatively, it can also be categorized as primary (idiopathic, not associated with other diseases or conditions) or secondary (attributed to underlying diseases or conditions, such as trauma, long-term medication, ophthalmic surgery, uveitis, necrotic tumors, diabetes or syndromic conditions) [11,12].

In primary OAG (POAG), aqueous humor drainage is obstructed or inadequate as there is an internal blockage within the TM [13]. In contrast, primary ACG (PACG) is characterized by the presence of a physical obstacle to the aqueous drainage as the iris is adhered to the cornea, obstructing the flow of aqueous humor to the TM and the uveoscleral drainage [12,14]. Symptoms appear more drastically in PACG, which results in a rapid reduction in the vision field, leading to total blindness. Other symptoms include ocular pain, headache, nausea, vomiting, multicolored halos and blurred vision [12]. Additionally, PACG is an ophthalmic emergency that requires immediate treatment to prevent the progression of irreversible ocular damage [12].

\section{Pathogenesis of Glaucoma}

The exact pathogenesis of glaucoma is complex and has not yet been fully elucidated. The potential mechanism involved in the neurodegeneration of glaucoma has been postulated to involve an amalgamation of mechanical, vascular, genetic and immunological factors.

\subsection{Mechanical Hypothesis}

The mechanical hypothesis explains the relationship between the IOP and RGC pathophysiology. The perforated lamina cribrosa (LC) is the weakest part of the sclera, and it is where the RGC axons pierce through the minute perforations to form the optic nerve, while the central retinal artery and vein pass through the LC via a larger central aperture [15]. Elevated IOP resulted from the imbalance between the production and drainage of aqueous humor, which led to the irreversible backwards bowing of the LC, in the process known as 'cupping' [16]. Optic nerve cupping is characterized by the remodeling of the extracellular matrix (ECM) and fibrosis in the LC [17]. Glaucomatous LC cells showed increased ECM gene expression and elevated intracellular calcium, which is known to promote proliferation, activation and contractility in fibroblasts via the nuclear factor of activated T cells/calcium signaling pathway [17]. This deformation damages the optic nerve and capillaries passing through the LC, disturbing the anterograde axonal transportation of RGCs, which then ultimately triggers visual field defects in glaucoma [16]. Furthermore, elevated IOP also resulted in activated pro-fibrotic pathway-induced ECM accumulation in the TM, leading to less efficient aqueous humor outflow, thereby causing further damage to the LC [18].

Ivers et al. [19] demonstrated that in experimental glaucoma monkeys, the first structural abnormality induced by elevated IOP was an increased anterior LC surface depth, followed by a decreased minimum rim width, and, lastly, a reduced retinal nerve fiber layer (RNFL) thickness. Different levels of increased IOP showed a remarkable effect on the visual field, best-corrected visual acuity and LC parameters (cup depth, LC depth, LC curvature index and prelaminar tissue thickness) [20]. Additionally, greater posterior displacement of the LC was significantly associated with a faster rate of loss of the RNFL [21]. RGC axonal degeneration and anterograde axonal transport deficits at the optic nerve head $(\mathrm{ONH}$, the location where RGC axons converge to form the optic nerve and traverse the LC) precede the structural and functional loss of RGCs [22]. Disturbance of the RGC 
anterograde axonal transport leads to the accumulation of metabolic waste in the cells and deprives the metabolic needs of the RGCs, subsequently causing their apoptosis [23].

In normal-tension glaucoma (NTG), patients also present with glaucomatous optic disc excavation, despite a normal IOP [24]. This suggests other risk factors are involved in the optic neurodegeneration of glaucoma. The LC serves as a barrier between the IOP within the eye, and the intracranial pressure within the cerebrospinal fluid-filled subarachnoid space surrounding the optic nerve; the pressure gradient between the LC is known as the translaminar pressure gradient (TLPG) $[25,26]$. The TLPG is higher in glaucoma patients, including NTG patients, and is associated with mechanical damage to the optic nerve fibers, anterograde axonal transportation disruption and altered blood flow, leading to glaucomatous damage [26-28].

\subsection{Vascular Hypothesis}

The blood flow of the $\mathrm{ONH}$ was significantly reduced in the eyes of pre-perimetric glaucoma patients, where there are characteristic glaucomatous changes in the optic disc, but without the presence of visual field defects $[29,30]$. POAG and PACG patients possess a lower capillary density, but with greater tortuosity and more dilated capillaries, compared to healthy individuals [31]. Similarly, both NTG and POAG patients showed lower retrobulbar velocities, and higher retinal venous saturation and choroidal thickness asymmetries, when compared to control subjects [32]. Decreased ocular blood flow was also shown to be correlated with structural glaucomatous progression, as indicated by retinal and optic nerve changes [33]. A recent retrospective longitudinal study revealed that reduced blood flow in the ONH precedes glaucomatous neurodegeneration in POAG patients [34]. The vascular hypothesis is thus based on the reduced perfusion pressure, faulty vascular autoregulation or loss of neurovascular coupling, which leads to optic nerve degeneration in glaucoma [35]. Due to the reduced ocular blood flow, this hypothesis proposes that the RGC axons suffer from oxygen and nutrient insufficiency, ultimately causing their degeneration. In a glaucoma rat model, ocular hypertension (OHT) led to selective hypoxia in the LC, which was associated with injured RGC axons, and axonal transport disruption [36]. This study also demonstrated upregulation of hypoxia-inducible enzyme heme oxygenase-1 (HO-1) and the anaerobic glycolytic enzyme lactate dehydrogenase, and increased generation of superoxide radicals in the retina and $\mathrm{ONH}$, as well as the active subunit of the superoxide-generating enzyme NADPH oxidase, suggesting the involvement of oxidative stress [36]. Similarly, hypoxic RGCs were observed in young and aged glaucoma model DBA/2J (D2) mouse retinas, with a significant increase in the hypoxia-inducible factor- $1 \alpha(\mathrm{HIF}-1 \alpha)$ protein and reactive oxygen species (ROS), followed by a significant decrease in the antioxidant capacity and mitochondrial mass in the aged retinas [37].

\subsection{Oxidative Stress and Neuroinflammation in Glaucoma}

In accordance with animal studies, numerous studies have provided evidence of increased oxidative stress in glaucoma patients. In addition, blood and aqueous humor levels of oxidative stress-related molecular biomarkers, i.e., protein carbonyls and advanced glycation end products, significantly increased in glaucomatous samples compared with healthy controls [38]. Similarly, PACG patients presented with decreased serum levels of total antioxidant status (TAS) and superoxide dismutase (SOD), as well as increased levels of malondialdehyde (MDA), compared to healthy controls [39]. A meta-analysis further indicated that POAG patients had lower TAS in the blood and higher levels of SOD, glutathione peroxidase (GPX) and catalase (CAT) in the aqueous humor [40]. Oxidative stress is known to induce or dysregulate inflammation in the event of optic neurodegeneration from glaucoma.

Studies have shown that inflammation contributes to the disease progression of glaucoma. In glaucomatous human optic nerves, the number of CD163+ cells (a commonly used marker for anti-inflammatory macrophages involved in tissue repair and remodeling) was 
significantly increased [41]. Systemic inflammatory status markers, i.e., the neutrophil-tolymphocyte ratio, platelet-to-lymphocyte ratio and systemic immune inflammation index, were significantly increased in POAG patients compared with the control group [42]. POAG patients exhibited a significant increase in various cytokines, i.e., serum interleukin (IL)-4, -6 and $-12 p 70$ and tumor necrosis factor-alpha (TNF- $\alpha$ ), compared with the controls [43]. Similarly, elevated plasma TNF- $\alpha$ levels in patients with POAG and pseudoexfoliation glaucoma were detected $[44,45]$. Additionally, aqueous humor samples collected from chronic PACG patients showed significantly increased levels of eotaxin, macrophage inflammatory protein-1-alpha and interferon gamma (IFN- $\gamma$ )-induced protein-10, and lower levels of TNF- $\alpha$, IL-5, -9 and -17 and granulocyte-macrophage colony-stimulating factor, compared to the control group [46].

Glial cells in the retina, i.e., astrocytes, Müller cells and microglial cells having an important role in mediating inflammatory responses, have been shown to become reactive, leading to the production of inflammatory cytokines, causing further neuronal damage in glaucoma patients and experimental glaucoma models [47,48]. In general, cytokine signaling is linked to the inflammatory transducer nuclear factor-kappa B (NF- $\mathrm{kB}$ ). In D2 mice, low energy-induced $5^{\prime}$ adenosine monophosphate-activated protein kinase (AMPK) phosphorylation in the retina and optic nerve triggered NF- $\mathrm{kB}$ p 65 signaling, leading to increased pro-inflammatory TNF- $\alpha$, IL-6 and nitric oxide synthase (NOS)-2 expression [49]. Injection administration of TGF- $\beta 2$ increased IOP and ECM deposition in the TM of wildtype mice. In contrast, mice harboring a mutation in NF- $\mathrm{kB}$ blocked the effect, suggesting NF- $\mathrm{KB}$ is necessary for TGF- $\beta 2$-induced ECM production and OHT [50]. Additionally, transgenic inhibition of astroglial NF- $\mathrm{KB}$ restrained the neuroinflammatory (reduced proinflammatory cytokine expressions, i.e., IL-1A, $-1 \mathrm{~B},-2,-6,-10,-12$ and -13 , TNF- $\alpha$ and IFN- $\gamma$ ) and neurodegenerative outcomes (attenuated loss of RGCs and axons) of the eyes of an experimental OHT mouse model [51].

The current evidence indeed supports the contribution of neuroinflammation in the pathogenesis of glaucoma, but it is still not clear as to when neuroinflammation takes part in the sequence of pathological events in glaucoma. Neuroinflammation has been suggested to be secondary to the initial pathology (i.e., optic nerve crush injury) [52]. Optic nerve crush injury induced glial activation in the retina, which was significantly muted if RGC death was blocked by deletion of the Bax gene [52]. On the other hand, the inhibition of monocyte infiltration and microglial activation by X-ray treatment prevented neuronal damage and dysfunction in the ONH [53]. Nevertheless, immunomodulation has been shown to be beneficial in the progression of glaucomatous changes.

\subsection{Excitotoxicity of Glutamate}

In addition to the inflammatory response, glial cells in the retina also play a vital role in the function of the retina by providing homeostatic and metabolic support to the photoreceptors and retinal neurons [54]. Müller cells and astrocytes possess uptake and exchange systems for various neurotransmitters, including glutamate, via the glutamate/aspartate transporter (GLAST) in rodents, also known as the $\mathrm{Na}^{+}$-dependent high-affinity glutamate transporter-1 (EAAT-1) in humans [54,55]. Glaucomatous eyes have been shown to have decreased levels of EAAT-1, and the glutamate receptor subunit $\mathrm{N}$-methyl-d-aspartate (NMDA)-R1 [56]. Furthermore, mice deficient in GLAST demonstrate spontaneous RGC loss and optic nerve degeneration without elevated IOP, suggesting the decrease in GLAST expression leads to glutamate excitotoxicity in the retina, as a possible pathogenesis of glaucoma [57].

As reviewed by others, perhaps the most accepted hypothesis involved in glaucoma pathogenesis currently may include the mechanical damage to the $\mathrm{ONH}$ induced by increased IOP, followed by vascular dysregulation (reduced ocular blood flow) and neuroinflammation (glial activation), which then disrupt axonal transport due to axonal mitochondrial function loss in the RGCs, ultimately leading to RGC axonal degeneration and 
RGC cell death (Figure 1) [58-60]. However, the combination of mechanisms described earlier may vary greatly among different glaucoma patients [60].

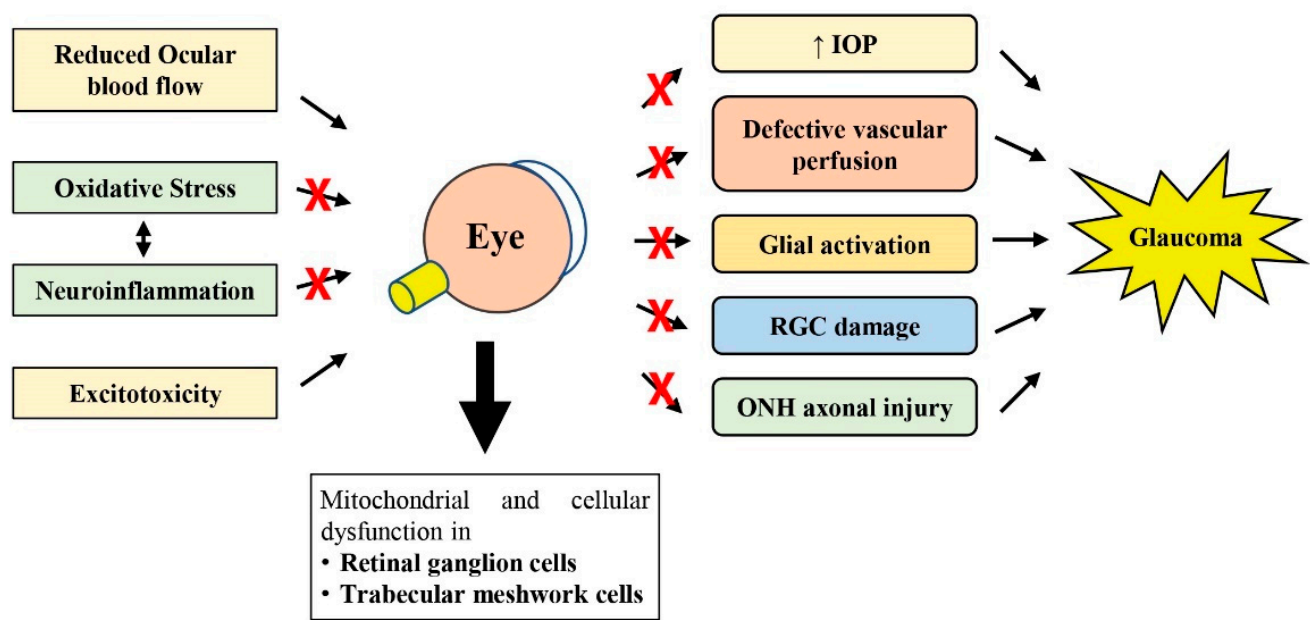

Figure 1. Schematic diagram showing how oxidative stress, neuroinflammation, reduced ocular blood flow and excitotoxicity lead to subsequent pathological changes observed in glaucoma. The therapeutic potential of natural products against glaucomatous changes at various steps is shown with the symbol $\times$. RGC, retinal ganglion cell; IOP, intraocular pressure; $\mathrm{ONH}$, optic nerve head.

\section{Glaucoma Research Models}

Numerous research models have been used to gain a considerable understanding of the pathogenesis of glaucoma, and to assess therapeutic approaches for glaucoma treatments [61-64]. In this section, we provide a brief overview of some of these models used by the studies presented in this review (summarized in Table 1); this helps to provide a better understanding of the discussions in the following sections.

There are several genetic glaucomatous animal models that present with an elevated or normal IOP. For instance, the D2 mouse presents a late-onset, chronic pigmentary glaucoma due to the high IOP that progresses with age, resulting from tyrosinase-related protein 1 (Tyrp1) mutation and a premature stop codon in glycoprotein non-metastatic melanoma protein B (Gpnmb), which collectively lead to anterior segment anomalies, iris atrophy, peripheral anterior synechiae and pigment dispersion $[64,65]$. In contrast, D2-Gpnmb ${ }^{+}$ mice are the wild types for the Gpnmb mutation that do not develop increased IOP and glaucoma [66]. Alternatively, the Vav2/Vav3-deficient and connective tissue growth factor ( $\beta$ B1-CTGF) mouse models are other murine models of spontaneous glaucoma that present with elevated IOP, which leads to subsequent RGC loss $[67,68]$. Transgenic mice with a low overexpression of E50K mutant optineurin (E50K-OPTN) have been reported to present with enhanced axonal degeneration and decreased RGC survival, under normal IOP [69].

Glaucoma can also be induced in wild-type animal models by elevating the IOP experimentally. A high IOP can be achieved by blocking aqueous humor drainage with the injection of various substances (e.g., microbeads, hydroxypropyl methylcellulose and hyaluronic acid) into the anterior chamber [70-72]. Alternatively, injection of hypertonic saline into the episcleral vein [73], and cauterization [74] or laser photocoagulation [75-77] of the episcleral or limbal veins lead to TM scarring, which increases the resistance to aqueous humor drainage, resulting in an elevation in IOP. The elevated IOP in these models leads to varying degrees of RGC loss, glial activation and visual defects [75-78].

To investigate the role of excitotoxicity in glaucoma, RGC loss can be induced with the injection of NMDA intravitreally [79]. The optic nerve crush (performed by applying a crush injury to the optic nerve with a pair of cross-action forceps) or the complete optic nerve transection model causes all RGC axons to be damaged simultaneously, which results in the gradual loss of RGCs [80,81]. This non-IOP-related axonal degeneration research model is commonly used to assess the RGC neuroprotection properties of various 
substances [82]. The partial optic nerve transection model causes damage to only a portion of the RGC axons; thus, this model can study both primary (the death of RGCs whose axons have been cut off) and delayed secondary neurodegeneration (the death of RGCs whose axons are intact) [83]. Retinal ischemia/reperfusion (I/R) injury is known to be associated with glaucoma, and other eye diseases, and has been widely used as an animal model for OAG. I/R injury reduces retinal blood flow, which creates a state of retinal hypersensitivity to oxygen and other nutrients, precipitating severe oxidative and inflammatory damage when the circulation is subsequently reinstated (reperfusion) $[84,85]$.

Table 1. Overview of glaucoma research models.

\begin{tabular}{|c|c|c|c|c|}
\hline Research Models & & Genes Involved & Mechanisms & References \\
\hline \multirow[t]{7}{*}{ Genetic in vivo model } & D2 mice & $\begin{array}{l}\text { Tyrosinase-related protein } 1 \\
\text { (Tyrp1) } \\
\text { Glycoprotein non-metastatic } \\
\text { melanoma protein B (Gpnmb) }\end{array}$ & $\begin{array}{l}\text { Blockage of aqueous humor } \\
\text { drainage, leading to } \\
\text { progressive elevated IOP }\end{array}$ & [65] \\
\hline & Methods & Surgery involved & Mechanisms & References \\
\hline & Injection & $\begin{array}{l}\text { Injection of microbeads into } \\
\text { the anterior chamber }\end{array}$ & $\begin{array}{l}\text { Blockage of aqueous humor } \\
\text { drainage, leading to } \\
\text { elevated IOP }\end{array}$ & [70] \\
\hline & & $\begin{array}{l}\text { Injection of hydroxypropyl } \\
\text { methylcellulose into the } \\
\text { anterior chamber }\end{array}$ & $\begin{array}{l}\text { Blockage of aqueous humor } \\
\text { drainage, leading to } \\
\text { elevated IOP }\end{array}$ & {$[71]$} \\
\hline & & $\begin{array}{l}\text { Injection of hyaluronic acid } \\
\text { into the anterior chamber }\end{array}$ & $\begin{array}{l}\text { Blockage of aqueous humor } \\
\text { drainage, leading to } \\
\text { elevated IOP }\end{array}$ & [72] \\
\hline & & $\begin{array}{l}\text { Injection of hypertonic saline } \\
\text { into the episcleral vein }\end{array}$ & $\begin{array}{l}\text { Produced scarring in the TM, } \\
\text { increasing resistance to } \\
\text { aqueous humor drainage, } \\
\text { leading to elevated IOP }\end{array}$ & [73] \\
\hline & & Intravitreal injection of NMDA & $\begin{array}{l}\text { NMDA induced excitotoxicity, } \\
\text { leading to RGC death }\end{array}$ & [79] \\
\hline \multirow[t]{6}{*}{$\begin{array}{l}\text { Experimental in vivo } \\
\text { model }\end{array}$} & $\begin{array}{l}\text { Cauterization/laser } \\
\text { photocoagulation }\end{array}$ & Episcleral vein cauterization & $\begin{array}{l}\text { Produced scarring in the TM, } \\
\text { increasing resistance to } \\
\text { aqueous humor drainage, } \\
\text { leading to elevated IOP }\end{array}$ & {$[74]$} \\
\hline & & $\begin{array}{l}\text { Argon laser photocoagulation } \\
\text { of the episcleral/limbal vein }\end{array}$ & $\begin{array}{l}\text { Produced scarring in the TM, } \\
\text { increasing resistance to } \\
\text { aqueous humor drainage, } \\
\text { leading to elevated IOP }\end{array}$ & \\
\hline & Nerve injury & Optic nerve crush & $\begin{array}{l}\text { Optic nerve injury leading to } \\
\text { axonal degeneration and } \\
\text { gradual RGC loss }\end{array}$ & {$[80]$} \\
\hline & & $\begin{array}{l}\text { Complete optic } \\
\text { nerve transection }\end{array}$ & $\begin{array}{l}\text { Optic nerve injury leading to } \\
\text { axonal degeneration and } \\
\text { gradual RGC loss }\end{array}$ & {$[81]$} \\
\hline & & Partial optic nerve transection & $\begin{array}{l}\text { Optic nerve injury leading to } \\
\text { axonal degeneration and } \\
\text { gradual RGC loss }\end{array}$ & [83] \\
\hline & Retinal I/R injury & $\begin{array}{l}\text { Reduced retinal blood flow by } \\
\text { induction of elevated IOP } \\
\text { (ischemia), followed by } \\
\text { reinstation of blood flow } \\
\text { (reperfusion) }\end{array}$ & $\begin{array}{l}\text { Extreme acute OHT-induced } \\
\text { ischemic injury to RGC, } \\
\text { followed by severe oxidative } \\
\text { and inflammatory damage to } \\
\text { RGCs after reperfusion }\end{array}$ & {$[84,85]$} \\
\hline
\end{tabular}

D2, DBA/2J; I/R, ischemia/reperfusion; IOP, intraocular pressure; NMDA, N-methyl-d-aspartate; RGC, retinal ganglion cell.

Numerous in vitro studies have utilized the RGC-5 cell line in glaucoma research to evaluate the neuroprotective properties of various supplements, including the studies reviewed here. However, it has now become clear that RGC-5 cells that were originally identified as immortalized rat RGCs were contaminated early in their development by the immortalized photoreceptor $661 \mathrm{~W}$ cell line (RGC precursor-like cells) in the laboratory they originated from $[86,87]$. Therefore, the RGC-5 cells used by many of the studies described in the following section may not reflect the true phenotype of a mature RGC. Perhaps the 
use of primary RGCs from animal models would be better to investigate glaucomatous RGC responses to therapies in vitro [88].

In general, the various research models described represent only some aspects of glaucoma, thus each having different advantages over other models. It is important to use a suitable model based on the objective of the study.

\section{Natural Products Used for Glaucoma Treatment and Their Mechanism of Action}

In view of the role played by oxidative stress and neuroinflammation in glaucoma, the use of antioxidants may represent an alternative approach for glaucoma treatment. Currently, the mainstay of glaucoma treatment is the reduction in IOP, using IOP-lowering eye drops [89]. Other glaucoma treatments include laser trabeculoplasty and cyclodestruction, or surgical trabeculectomy, trabeculotomy, deep sclerectomy and viscocanalostomy, based on the European Glaucoma Society guidelines [90]. However, even when the IOP normalizes, the disease still progresses and affects visual function in some patients.

There has been significant research interest in complementary and alternative medicine (CAM), and it has been widely used in the treatment of glaucoma. In a survey involving a total of 1516 glaucoma patients in Canada, $10 \%$ of patients used CAM therapy specifically for glaucoma, and half of them believed that the treatments were beneficial [91]. Other recent surveys reported the prevalence of CAM usage to be 22\% in Saudi Arabia and 67\% in Palestine among eye patients [92,93]. The present review highlights recent studies on various CAMs used for the treatment of glaucoma.

\subsection{Gingko biloba L.}

Ginkgo biloba L. (GB) belongs to the Ginkgoceae family, and its leaves and seeds have been used for medicinal purposes for centuries [94]. With more than 70 different flavonoids having been identified in GB, it has been suggested to have broad-spectrum free radical scavenging activities [95]. Indeed, treatment with GB extract was able to increase the survival of a rat RGC line, following exposure to oxidative stress induced by hydrogen peroxide $\left(\mathrm{H}_{2} \mathrm{O}_{2}\right)$ [96]. Furthermore, POAG patients treated with $120 \mathrm{mg}$ of GB extract daily for at least 6 months demonstrated a lower rate of single-stranded DNA breaks in circulating leukocytes, indicating reduced oxidative stress [97].

Numerous clinical trials have also demonstrated that GB extract supplementation slows the progression of visual field damage and improves visual function in NTG patients $[98,99]$. However, Shim et al. [99] demonstrated that supplementation with $40 \mathrm{mg}$ of GB extract, three times per day, showed no effect on the mean defect or contrast sensitivity in NTG patients, compared to those receiving placebo. Based on the vascular hypothesis of glaucoma pathogenesis, NTG patients receiving $80 \mathrm{mg}$ GB extract tablets, twice a day for four weeks, showed a significant increase in ocular blood flow, volume and velocity, in comparison to the placebo group [100]. Furthermore, GB supplementation increased the radial peripapillary capillary vascular density in healthy subjects who received a $120 \mathrm{mg}$ GB extract capsule daily for 4 weeks [101]. Table 2 summarizes clinical trials of natural products used for glaucoma treatment.

In animal studies, intraperitoneal injections of GB extract administered after optic nerve injury in rats were associated with a higher survival rate of RGCs $[96,102]$. This could be due to the anti-apoptosis property of GB, as demonstrated by the inhibition of apoptosis of RGCs via the modulation of mitogen-activated protein kinase (MAPK) signaling pathways, in the adult rat optic nerve injury model, following the retrobulbar injection of diterpene ginkgolides meglumine injection (DGMI, made from GB extracts, including ginkgolides A, B and K) [103]. Mechanistically, DGMI could inhibit cell apoptosis by inhibiting p38, JNK and Erk1/2 activation [103]. Additionally, GB extract-derived procyanidin $\mathrm{B} 2$ and rutin were shown to be able to protect human retinal pigment epithelial cells subjected to tert-butyl hydroperoxide-induced oxidative stress by modulating nuclear factor erythroid 2-related factor (Nrf)-2 and Erk1/2 signaling [104]. Another study proposed that P53, Bax, Bcl-2 and caspase-3/-9 could be considered as the core targets for GB extract 
against apoptosis in $\mathrm{H}_{2} \mathrm{O}_{2}$-treated RGCs [105]. A summary of preclinical studies of natural products used for glaucoma treatment is provided in Table 3.

\subsection{Scutellaria baicalensis Georgi-Baicalin, Baicalein and Wogonin}

Scutellaria baicalensis Georgi, commonly known as Baikal skullcap or Chinese skullcap, is a widely used Chinese medicinal herb [106]. S. baicalensis extract and its three major active flavonoids, namely, baicalin, baicalein and wogonin showed low cytotoxicity and possessed neuroprotective, antioxidant, anti-inflammatory and anti-cancer properties [106-108].

Intragastric administration of $200 \mathrm{mg} / \mathrm{kg}$ of baicalein for 28 days significantly reduced IOP in a rat model of chronic OHT [109]. The decreased thickness of the RGC complex and the reduced nucleus of the RGC layer mediated by OHT were significantly ameliorated by baicalein treatment and associated with reduced apoptosis of RGCs by upregulating the expression of the anti-apoptotic protein Bcl-2 [109]. Additionally, baicalein protects RGCs against retinal ischemia via the downregulation of HIF- $1 \alpha$, matrix metalloproteinase (MMP)-9 and vascular endothelial growth factor (VEGF), and upregulation of HO-1 [110].

The intraperitoneal administration of wogonin, $10 \mathrm{~min}$ after the establishment of the optic nerve crush rat model, reduced the loss of RGCs and inhibited RGC apoptosis [111]. The study also demonstrated the anti-inflammatory property of wogonin in preventing TLR4-NF- $\kappa$ B-mediated neuroinflammation, as indicated by the reduced gliosis response, microglial activation and pro-inflammatory cytokine (TNF- $\alpha$, monocyte chemoattractant protein-1 (MCP-1), iNOS, IL-6 and $-1 \beta$ and cyclooxygenase (COX-2)) expressions in the retina following optic nerve crush [111].

Intraperitoneal administration of baicalin increased the number of RGCs and attenuated pathological changes (indistinct layer of retinas, decrease in the thickness of the RGC layer (GCL, a retinal layer where RGCs and displaced amacrine cells reside) and RGC density) in a model of episcleral venous occlusion with cauterization to establish a mouse model of glaucoma with chronic elevated IOP [112]. Baicalin treatment also inhibited autophagy and activated PI3K/AKT signaling in glaucoma mice, as PI3K/AKT signaling was shown to restrain the apoptosis and inflammatory response of RGCs in glaucoma development [112]. Additionally, treatment with baicalin significantly increased cell survival, reduced ROS production and inhibited pro-inflammatory factor IL- $1 \alpha$ and endothelial leucocyte adhesion molecule-1 (ELAM-1) production in cultured human TM cells exposed to $\mathrm{H}_{2} \mathrm{O}_{2}$ [113].

\subsection{Coleus forskohlii (willd.) Briq.-Forskolin}

Coleus forskohlii (willd.) Briq. is a medicinal plant indigenous to India and Southeast Asia [114]. The leaves, roots and tubers of $C$. forskohlii are a rich source of a diterpenoid called forskolin, which acts as a second messenger cyclic adenosine $3^{\prime}, 5^{\prime}$-monophosphate (cAMP) booster, via the direct stimulation of adenylate cyclase [114]. Studies have revealed that cAMP is important in regulating aqueous humor dynamics in the ciliary body and TM [115]. Indeed, a previous study has shown that forskolin perfused arterially at 30, 100 and $1000 \mathrm{nM}$ caused a significant reduction in the rate of aqueous humor formation in an isolated bovine eye preparation [116]. This may explain the hypotensive effect of forskolin administration, as shown in a double-blind, randomized controlled trial where POAG patients treated with forskolin $1 \% w / v$ aqueous solution eye drops, at two drops thrice a day, for 4 weeks, showed a significant decrease in IOP [117,118].

In animal studies, a dietary combination of forskolin, homotaurine, spearmint and vitamins B1, B6 and B12 was able to protect against RGC loss in a rodent model of optic nerve injury [119] and hypertensive glaucoma [120]. Both studies demonstrated that the forskolin supplement mixture may counteract the inflammatory processes via the reduction in cytokine (iNOS, IL-6 and TNF- $\alpha$ ) secretion, thereby leading to decreased apoptotic markers (Bax/Bcl-2 ratio and active caspase-3), finally sparing RGC death and the preservation of visual function $[119,120]$. However, in contrast to the clinical studies, the forskolin supplement mixture did not affect IOP elevation in glaucomatous rodents [120]. 


\subsection{Erigeron breviscapus (vant.) Hand. Mazz.-Scutellarin}

Erigeron breviscapus (vant.) Hand. Mazz. (DengZhanHua in Chinese) is a dicotyledonous plant in the Compositae chrysanthemum family found primarily in southwest China, especially in Yunnan [121]. It has been used in traditional Chinese medicine, for the prevention and treatment of cardiovascular diseases [121]. E. breviscapus supplements administered for 6 months showed no obvious adverse effects, with a significant decrease in the mean defect and an increase in the mean sensitivity, in POAG patients with a controlled IOP, demonstrating its partial protective effect on the visual field in glaucoma [122]. In chronic elevated IOP animal models, E. breviscapus oral supplements were shown to reduce IOP, improve impaired visual function, increase the RGC density and reduce RGC axonal degeneration caused by elevated IOP [123,124]. In RGCs, E. breviscapus extract was shown to suppress the outward potassium channel currents, which was suggested to be one of the key mechanisms behind E. breviscapus's beneficial effects against glaucoma-induced RGC damage and visual impairment [125].

The flavonoid scutellarin is one of the major constituents of E. breviscapus. A 3-week oral scutellarin treatment ameliorated retinal thinning and visual deficits in an induced chronic OHT glaucoma model [126]. Scutellarin protected RGCs and reduced impaired retinal microglial cells by inhibiting NLRP3 inflammasome-mediated inflammatory reactions, which was associated with a reduced upregulation of apoptosis-associated speck-like protein (a caspase recruitment domain), cleaved caspase- 1 and IL-18 and $-1 \beta$ following acute OHT [127].

\subsection{Lycium barbarum L.}

Lycium barbarum L., commonly known as goji berry or wolfberry, has been widely used in China to treat various diseases, i.e., blurry vision, abdominal pain, infertility, dry cough, fatigue, dizziness and headaches, and has been used as a potent anti-aging agent [128]. The most abundant component in goji berries is represented by carbohydrates, and isolated L. barbarum polysaccharides (LBPs) have been found to exert various pharmacological properties, i.e., neuroprotective, hypoglycemic, anti-cancer, immunomodulatory and antioxidant properties $[129,130]$. LBP supplementation has been shown to protect RGC survival and preserve retinal function in various glaucoma models, i.e., acute OHT [131,132], chronic OHT $[133,134]$ and partial optic nerve transection [135]. In the partial optic nerve transection model, LBP pre-treatment for 7 days prior to the injury was shown to delay secondary degeneration of RGCs [136]. The study also reported LBP exerting its neuroprotective effects by inhibiting oxidative stress and the JNK/c-jun pathway, and by transiently increasing the expression of insulin-like growth factor-1, which is a known neurotrophic factor determining the survival of RGCs during the early stages of optic nerve injury [136].

LBP has been shown to protect RGCs against oxidative stress injury by inhibiting the generation of ROS and reducing the mitochondrial membrane potential following cobalt chloride $\left(\mathrm{CoCl}_{2}\right)$-induced hypoxia [137]. Additionally, LBP significantly promoted cell viability, reduced apoptosis and decreased cleaved caspase-3/-9 and ROS levels in human TM cells after $\mathrm{H}_{2} \mathrm{O}_{2}$ administration [138]. Alternatively, LBP treatment has been shown to promote $\mathrm{M} 2$ polarization of microglia and downregulate autophagy after partial optic nerve resection, which contributes to the delayed secondary degeneration of RGCs [139]. Other studies have also suggested that LBP provides neuroprotection to the RGCs and retina by inhibiting vascular damage, probably via the regulation of endothelin-1 (ET1)-mediated biological effects [131,133]. In a recent study, LBP treatment also promoted blood-retinal barrier maintenance and survival of RGCs in acute OHT mice, which were mediated through the regulation of amyloid- $\beta$ production and advanced glycosylation end product receptor expression [140]. Furthermore, L. barbarum ethanolic extracts reduced angiopoietin-like 7 protein (ANGPTL7) expression while increasing that of caveolin-1 in PC12 neuronal cells exposed to hydrostatic pressures, which was associated with decreased gene expressions of ECM proteins, i.e., MMP-2, MMP-9, collagen I and TGF- $\beta$ [141]. Previous studies have indeed indicated that ANGPTL7 modulates the TM's ECM [142] and 
MMP-mediated ECM turnover in the TM, which leads to a reduction in outflow resistance in the conventional outflow pathway, and to maintenance of IOP homeostasis [143].

LBP treatment significantly reduced neuronal death and glial activation in the retina following I/R injury [144,145]. Furthermore, LBP treatment was able to alleviate ischemiainduced retinal dysfunction (exhibiting greater $b$-wave and oscillatory potential responses) $[144,146]$. The antioxidant levels (glutathione, SOD and CAT) in the retina were significantly higher, while the MDA level was lower, in the submicron and blended L. barbarum extract-treated groups, compared to the control [146]. Further studies demonstrated that LBP exerted its neuroprotective effects via the activation of Nrf2 and an increase in $\mathrm{HO}-1$ protein expression in the retina after I/ R injury [145].

\subsection{Diospyros kaki L.}

Persimmon (Diospyros kaki L.), belonging to the family Ebenaceae, is a well-known fruit rich in carbohydrates, dietary fibers, vitamins, minerals, carotenoids, phenolic compounds and other bioactive phytochemicals [147]. In addition to its fruit, persimmon's leaves are also rich in flavonoids that exhibit antioxidant properties [148]. Pre-treatment of RGCs exposed to excessive oxidative stress and excitotoxicity with an ethanolic extract of persimmon leaves (EEDK) increased cell viability in a concentration-dependent manner [149]. Further studies revealed that the neuroprotective effect of EEDK was associated with decreased levels of apoptotic markers, i.e., poly (ADP-ribose) polymerase, p53 and cleaved caspase-3, and increased expression levels of antioxidant enzymes, i.e., SOD, GPX and glutathione S-transferase [149]. The same study demonstrated that EEDK treatment protects the retina and RGCs in a partial optic nerve crush mouse model [149]. Additionally, EEDK was also shown to reduce elevated IOP in a glaucoma mouse model, by regulating the soluble guanylate cyclase $\alpha-1$ (sGC $\alpha-1$, a primary regulator of vascular hypertension) signal [150].

\subsection{Tripterygium wilfordii Hook F.-Triptolide and Celastrol}

Tripterygium wilfordii Hook F., commonly known as thunder god vine, is a traditional Chinese medicine widely used to treat autoimmune and inflammatory diseases including rheumatoid arthritis, systemic lupus erythematosus and dermatomyositis [151]. Triptolide and celastrol are the predominant active phytochemicals isolated from this plant, which exhibit similar pharmacological activities, i.e., anti-cancer, anti-inflammatory, immunosuppressive, anti-obesity and anti-diabetic activities [152]. Triptolide treatment improved RGC survival via the inhibition of microglial activation in glaucoma models [153-155]. Additionally, triptolide treatment inhibited the expression of TNF- $\alpha$ and the nuclear translocation of NF- $\kappa B$ in an optic nerve crush model, suggesting that the neuroprotective effect of triptolide was attributed, partly, to its anti-inflammatory property [155]. Similarly, celastrol treatment also improved RGC survival in glaucoma models [156,157].

\subsection{Crocus satious L.-Crocetin and Crocin}

Saffron (the dried stigma of Crocus sativus L.) is a spice that is widely used in food preparation, as a flavoring and coloring agent [158]. Referred to as the 'golden spice', saffron is the highest-priced aromatic medicinal plant in the world, with numerous pharmacological properties such as anti-cancer, anti-diabetic, anti-inflammatory, antioxidant, immunomodulatory, antifungal and antimicrobial properties [158]. Oral administration of saffron extract was shown to decrease microglial numbers and their activation following increased IOP, and this led to the prevention of RGC death [159]. A randomized interventional pilot study revealed that $30 \mathrm{mg} /$ day saffron supplementation significantly reduced IOP in POAG patients, after 3 weeks of treatment [160].

More than 150 chemical compounds have been extracted from saffron, with crocin and crocetin being the two major active ingredients [161]. Intraperitoneal treatment with crocin can inhibit I/R-induced RGC death, and the effect of crocin may be mediated, partly, by its antioxidant action through the ERK pathway [162], or activation of the PI3K/AKT 
signaling pathway [163]. Additionally, crocin protects RGCs against $\mathrm{H}_{2} \mathrm{O}_{2}$-induced damage by reducing ROS production and activating NF- $\kappa B$ [164]. Similarly, crocetin, an aglycone of crocin, prevented cell loss and apoptosis in the GCL in mice following NMDA- [165] and I/R-induced retinal damage [166].

\subsection{Curcuma longa L.-Curcumin}

Curcumin is a yellow pigment and an active component of the rhizome of Curcuma longa L., or turmeric [167]. It is known to possess antioxidant, anti-inflammatory, anti-cancer, anti-arthritis, anti-asthmatic, antimicrobial, antiviral and antifungal properties $[167,168]$. Considering that curcumin is a powerful antioxidant natural compound, it may represent another potential treatment to alleviate oxidative stress in glaucoma. Using an elevated IOP rodent model, curcumin treatment decreased the intracellular level of ROS and alleviated RGC apoptosis induced by oxidative stress [169]. In the same study, it was also observed that curcumin inhibited pro-apoptotic factors, such as caspase- 3 and Bax, and upregulated the anti-apoptotic factor Bcl-2 [169]. In an ex vivo optic nerve injury model, thinning of retinal layers, especially the GCL, and strong RGC apoptosis were observed after $24 \mathrm{~h}$ post-injury, which correlated with a time-dependent increase in caspase-3 and -9 and pro-apoptotic marker levels, and a powerful activation of the JNK, c-Jun and ERK signaling (MAPK) pathways [170]. Curcumin prevented alterations in the apoptotic cascade and MAPK pathways, preserving RGC survival and retinal thickness [170]. In another experimental study in a rat retinal I/ $R$ injury model, curcumin supplementation in the diet for 2 days before I/R was able to protect the retina from ischemic injury [171]. Additionally, curcumin pre-treatment inhibited I/R-induced degeneration of retinal capillaries, which may occur through its inhibitory effects on injury-induced activation of NF- $\mathrm{KB}$ and signal transducer and activator of transcription 3 (STAT3), and on overexpression of MCP-1, a chemokine involved in the inflammatory response via recruitment of monocytes to injury sites [172].

Studies using TM cells exposed to $\mathrm{H}_{2} \mathrm{O}_{2}$-induced oxidative stress as an in vitro model observed that pre-treatment with curcumin reduced the production of intracellular ROS in a dose-dependent manner $[173,174]$. Curcumin alleviated oxidative stress-induced proinflammatory factors such as IL-1a, -6 and -8 and ELAM-1 and inhibited the apoptosis of TM cells [173]. Curcumin has also been shown to protect TM cells against oxidative stress and apoptosis via the Nrf2-keap1 pathway [174].

\subsection{Camellia sinensis (L.) Kuntze-Epigallocatechin-3-Gallate}

Camellia sinensis (L.) Kuntze, commonly known as green tea, is consumed as a beverage and is popular in China and Japan [175]. Green tea extract treatment administered orally to retinal I/R injury rats showed a higher number of surviving RGCs, and less apoptotic RGCs were observed [176]. Green tea extract treatment also reduced the increased protein expression (i.e., of apoptotic markers (activated caspase-3 and -8) and inflammation-related proteins (Toll-like receptor 4 (TLR4), IL-1 $\beta$ and TNF- $\alpha$ )) and p38 phosphorylation caused by the ischemic injury [176]. Additionally, green tea extract treatment led to suppression of activated microglia, astrocytes and Müller cells following lipopolysaccharide (LPS)-induced retinal inflammation in rats [177]. The green tea anti-inflammatory effects were associated with a reduction in the phosphorylation of STAT3 and NF- $\mathrm{KB}$ in the retina [177].

The major polyphenolic compounds contained in green tea are catechins, which include epigallocatechin-3-gallate (EGCG), which is also a powerful antioxidant, antiangiogenic and anticarcinogenic agent $[175,178]$. EGCG treatment was shown to preserve the RGC density in acute [179] and chronic elevated IOP rats [180], an optic nerve crush rat model [181], a retinal I/R injury rabbit model [182] and NMDA-induced excitotoxicity in rats [183]. Zhang et al. [179] reported that EGCG treatment significantly decreased inflammation-associated cytokine levels (IL-4, $-6,-1 \beta$ and -13 , TNF- $\alpha$ and IFN- $\gamma$ ), and the proliferation rate of T lymphocytes. Furthermore, EGCG treatment inhibited the increase in the phosphorylation of nuclear factor of kappa light polypeptide gene enhancer in B cells 
inhibitor, alpha $(\mathrm{I} \kappa \mathrm{B} \alpha)$ and $\mathrm{p} 65$, leading to the suppression of NF- $\mathrm{kB}$ signaling pathway activation [179].

\subsection{Panax ginseng-Ginsenoside}

Panax ginseng, in the family Araliaceae, is considered as one of the most frequently employed medicinal herbs and functional foods [184,185]. In a randomized, placebocontrolled, crossover study, daily consumption of $3 \mathrm{~g}$ of Korean red ginseng (KRG) for 4 weeks was shown to improve daytime contrast sensitivity and ocular pain in glaucoma patients [186]. Following 8 weeks of KRG supplementation, glaucoma patients showed significant improvement in their tear film stability and total Ocular Surface Disease Index score, suggesting KRG improved dry eye syndrome in glaucoma patients [187]. Additionally, OAG patients receiving $1.5 \mathrm{~g}$ of KRG, orally 3 times daily for 12 weeks, showed significant improvement in the retinal peripapillary blood flow in the temporal peripapillary region [188].

Ginseng contains numerous phytochemicals such as ginsenoside (triterpenoid saponin), phenols and acidic polysaccharides [189]. These phytochemicals have been shown to protect RGCs. Total Panax notoginseng saponin treatment increased RGC survival and inhibited the cell apoptosis pathway induced by an optic nerve crush rat model [190]. Similarly, ginsenoside Rg1 treatment was able to reduce RGC damage in an ultrasound-targeted microbubble optic nerve damage rabbit model [191]. Furthermore, ginsenoside Rb1 protects RGCs against apoptosis caused by $\mathrm{CoCl}_{2}$-induced hypoxia and $\mathrm{H}_{2} \mathrm{O}_{2}$-induced oxidative stress [192].

\subsection{Cannabis sativa-Cannabinoids}

Cannabis sativa, commonly known as marijuana, is one of the most used psychoactive substances in the world [193]. The C. sativa plant contains more than 60 lipid-based cannabinoids, which are the signaling molecules of the endocannabinoid system; these include $\Delta$-9-tetrahydrocannabinol ( $\Delta^{9}$-THC), $\Delta$-8-tetrahydrocannabinol ( $\Delta^{8}$-THC), cannabidiol and cannabinol [194]. A reduction in IOP was observed in glaucoma patients associated with tachycardia, within the first $30 \mathrm{~min}$ after marijuana inhalation, with the duration of action limited to $4 \mathrm{~h}$ [195]. Similarly, $\Delta^{9}$-THC inhalation reduced IOP significantly from baseline in healthy adult subjects, detected from 40 min post-treatment and lasting up to $4 \mathrm{~h}$ [196].

In animal studies, a topically applied $2 \% \Delta^{9}$-THC ophthalmic solution was shown to reduce IOP in clinically normal dogs [197]. To prolong the IOP reduction duration, the use of $\Delta^{9}$-THC-valine-hemisuccinate nanoemulsions, which help to increase absorption, produced a greater drop in IOP, compared to latanoprost and timolol in normal rabbits [198]. Similarly, a submicron emulsion of $\Delta^{8}$-THC treatment to normal and OHT rabbits also demonstrated a reduced IOP [199]. The IOP-lowering and RGC neuroprotective effects of cannabinoids have been shown to be mediated by CB1 cannabinoid receptors $[200,201]$.

\subsection{Anthocyanins}

Anthocyanins, considered as flavonoids, are blue, red or purple pigments commonly found in the flowers, fruits and tubers of many plants [202]. Hence, the primary sources of anthocyanins are found in berries, currants, grapes and some tropical fruits [202]. Studies have demonstrated that anthocyanins provide numerous health benefits such as antioxidative and neuroprotective properties, prevention of cardiovascular diseases, anti-angiogenesis, anti-cancer, anti-diabetic, anti-obesity and antimicrobial activities and improved visual health [202,203].

OAG patients receiving supplementation of $50 \mathrm{mg}$ of black currant anthocyanins daily for 24 months also showed a reduced IOP and improved visual field damage progression [204]. Black currant anthocyanin supplementation also enhanced blood flow to the $\mathrm{ONH}$ and its surrounding retina in OAG patients, with no changes in systemic conditions such as blood pressure and pulse rates observed [204,205]. Black currant anthocyanin supplementation also normalized the abnormal serum concentration levels of ET-1 in OAG 
patients, suggesting that anthocyanins possibly affect the ET-1 receptor functions such as pharmacological reactivity and hypersensitivity [206].

The natural anthocyanins delphinidin, luteolinidin and peonidin were shown to be non-toxic to human retinal pigment epithelial (ARPE19) and RGC-5 cells, with luteolinidin and peonidin increasing the survival rates of the RGC-5 cells following exposure to $\mathrm{H}_{2} \mathrm{O}_{2}$ [207]. Administration of oral bilberry extracts rich in anthocyanins was shown to suppress RGC death following an optic nerve injury mouse model [208]. Bilberry extract administration increased chaperone molecule (Grp78 and Grp94) protein levels, an effect which may underlie the neuroprotective effect of bilberry extract after optic nerve crush [208]. In a model of light-induced retinal damage in pigmented rabbits, administration of bilberry anthocyanin extract at dosages of 250 and $500 \mathrm{mg} / \mathrm{kg} /$ day for 7 days significantly inhibited retinal dysfunction, as evidenced by the increased retinal outer nuclear layer thicknesses and lengths of the outer segments of the photoreceptor cells, compared to untreated rabbits with retinal degeneration [209]. Additionally, anthocyanin treatment attenuated the changes caused by light to the apoptotic proteins Bax, Bcl-2 and caspase- 3 and increased the antioxidant enzyme levels (SOD, GPX and CAT), but it decreased the MDA level in the retinal cells [209].

\subsection{Resveratrol}

Resveratrol (trans-3, $4^{\prime}, 5$-trihydroxystilbene) is a polyphenol found in berries, grapes, pomegranates and red wine [210]. It has been reported to possess a wide range of pharmacological effects, including cardioprotection, neuroprotection and anti-diabetic activity, due to its potent antioxidant and anti-inflammatory properties [210]. Resveratrol has been reported to increase oxidative stress markers, and the nitric oxide level in human glaucomatous TM cells, possibly by increasing endothelial nitric oxide synthase (eNOS) expression and reducing inducible NOS expressions [211]. In experimental glaucoma models, resveratrol treatment was shown to reduce RGC death [212,213]. Cao et al. [213] further demonstrated that intravitreal administration of resveratrol rescued RGCs by the decreased ROS generation in RGCs of a microbead-induced high-IOP mouse model. These studies support the antioxidant properties of resveratrol, which could be beneficial in glaucoma treatment.

Resveratrol protects RGC- 5 cells against $\mathrm{H}_{2} \mathrm{O}_{2}$-induced apoptosis, by reversing $\mathrm{H}_{2} \mathrm{O}_{2}-$ induced increased expressions of cleaved caspase-3/-9, production of ROS and the expressions of $p$-p38, $p$-ERK and $p$-JNK, proposing that resveratrol suppresses MAPK cascades to exert its neuroprotective effects in RGCs [214]. Additionally, resveratrol also mitigates retinal I/R injury-induced RGC loss, glial activation and retinal function impairment by inhibiting the HIF-1a/VEGF and p38/p53 pathways while activating the PI3K/AKT pathway [215-217].

In both the chronic OHT rat model and RGC- 5 cells incubated under elevated pressure, RGCs showed apoptosis and mitochondrial dysfunction [218]. Resveratrol treatment improved the expression of proteins involved in mitochondrial biogenesis and dynamics, i.e., AMPK, Nrf-1, mitochondrial transcription factor A (Tfam), mitofusin 2 (mfn-2) and optic atrophy 1 (OPA1), which led to a decrease in RGC apoptosis, mitochondrial membrane potential depolarization and ROS generation $[218,219]$. Another recent study identified a potential mechanism involving the protective role of resveratrol in preventing $\mathrm{ONH}$ astrocyte dysfunction and degeneration, which would enable the astrocytes to continue providing structural and nutrient support to the optic nerve [220].

\subsection{Hesperidin}

Hesperidin is a flavanone commonly found in citrus fruits such as oranges, tangerines, lemons and grapefruits, known for its anti-inflammatory, antioxidant and anticarcinogenic properties [221]. The antioxidant profile of a novel supplement containing hesperidin, and two other food-derived antioxidants, i.e., crocetin and Tamarindus indica (tamarind), was assessed in a prospective, single-arm design trial involving 30 NTG patients receiving 
the supplements for 8 weeks [222]. In patients with relatively high oxidative stress, the supplement significantly reduced the urinary 8-hydroxy-2'-deoxyguanosine (8-OHdG; a marker of oxidative DNA damage) level, and the biological antioxidant potential was also significantly elevated [222].

In an animal study, a single dose of oral hesperidin pre-treatment $(25,50$ and $100 \mathrm{mg} / \mathrm{kg})$ significantly reduced the increased IOP level in dextrose- and prednisolone acetate-induced $\mathrm{OHT}$ rats [223]. Additionally, hesperidin treatment increased the glutathione level in the aqueous humor and reduced morphological alteration in the ciliary bodies caused by elevated IOP [223]. Furthermore, hesperidin treatment ameliorated NMDA-induced retinal injury by suppressing oxidative stress [224] and excessive calpain activation [225] while also alleviating hypobaric hypoxia-induced retinal impairment through the activation of the Nrf2/HO-1 pathway [226].

\subsection{Caffeine}

Caffeine (1,3,7-trimethylxanthine) is a natural alkaloid commonly consumed through coffee, tea, carbonated soft drinks, energy drinks, chocolate and other cocoa-containing foods [227]. Caffeine acts as a central nervous system stimulant through its $A_{1}$ and $A_{2 a}$ adenosine receptor antagonist properties [227]. The effect of caffeine consumption on IOP was found to be controversial in the literature. Tran et al. [228] demonstrated a reduced IOP following 45 and 60 min consumption of caffeine in POAG patients, when compared to the water-drinking group. However, another study reported that $1 \%$ caffeine eye drops administered daily for a week showed no effect on IOP in POAG patients [229]. In contrast, healthy individuals receiving a single dose of a $4 \mathrm{mg} / \mathrm{kg}$ caffeine capsule showed an increase in IOP, with low-caffeine consumers reporting a more abrupt IOP increase compared to the high-caffeine consumers [230]. Further studies suggested the increase in IOP was associated with a reduction in the anterior chamber angle, which led to resistance to aqueous humor outflow [231]. Recent cross-sectional studies showed caffeine consumption was weakly associated with a lower IOP but was not associated with a decreased risk of developing glaucoma [232,233]. An in vivo study demonstrated a reduced IOP and prevention of loss of RGCs in the caffeine-drinking animals following laser-induced OHT in experimental rats [234]. However, the same study also reported that caffeine treatment did not ameliorate OHT-induced impairment in the RGC retrograde transport, although caffeine treatment appeared to partially attenuate axonal degeneration of the optic nerve induced by OHT [234]. Interestingly, caffeine drinking led to increased microglia reactivity, inflammatory response (IL-1 $\beta$ and TNF mRNA levels) and cell death following $24 \mathrm{~h}$ post-I/R injury in a mouse model, which were then reduced at day 7 postinjury [235]. Additionally, caffeine was shown to preserve the integrity of the blood-retinal barrier in LPS-treated ARPE19 cells, which can be considered as a new strategy to treat retinal degenerative diseases [236].

\subsection{Coenzyme Q10}

Coenzyme Q10 (CoQ10), or ubiquinone-10, is a natural lipophilic vitamin-like molecule with antioxidant and anti-inflammatory properties and is involved in the production and control of cellular bioenergy, pyrimidine synthesis, physicochemical properties of cellular membranes and gene expression $[237,238]$. It is predominantly found in animal organs (kidney, liver and heart) and is also present in meat, fish, soy oil and peanuts [238].

Treatment with CoQ10, either topically applied or supplemented in the diet, was shown to promote RGC survival by inhibition of RGC apoptosis in glaucoma models [239-241]. CoQ10 treatment has also been shown to inhibit glaucomatous mitochondrial alteration by the preservation of the mtDNA content and Tfam/oxidative phosphorylation (OXPHOS) complex IV protein expressions [239,240]. Furthermore, CoQ10 treatment inhibited the activation of astrocytes and microglial cells in the retina [239,240]. In a clinical study, CoQ10 and vitamin E eye drop administration in POAG patients for 12 months showed a beneficial effect on the inner retinal function (PERG improvement), with a conse- 
quent enhancement of the visual cortical responses (VEP improvement) [242]. Additionally, CoQ10 and vitamin E topical treatment increased RGC numbers, inhibited apoptosis and activated astrocytes and microglial cells in a mechanical optic nerve injury rat model [243].

\subsection{Vitamins}

A cross-sectional study involving a total of 2912 participants in the United States 2005-2006 National Health and Nutrition Examination Survey reported that supplementary consumption and serum levels of vitamins $\mathrm{A}$ and $\mathrm{E}$ were not associated with glaucoma prevalence [244]. A meta-analysis did not find an association between serum vitamin $B_{6}$, vitamin $B_{12}$ and vitamin $D$ levels and different types of glaucoma [245]. Another recent systematic review concluded that blood levels of vitamins (A, B complex, C, D and E) did not demonstrate an association with OAG as well [246]. However, the same study reported that dietary intake of vitamins $A$ and $C$ showed a beneficial association with OAG [246].

The nicotinamide adenine dinucleotide $\left(\mathrm{NAD}^{+}\right.$, an important metabolite for mitochondrial metabolism and oxidative stress protection) level in the retina of D2-Gpnmb ${ }^{+}$mice decreased with age [247]. Oral administration of vitamin $B_{3}$ (nicotinamide, precursor of $\mathrm{NAD}^{+}$) was protective as both prophylaxis and an intervention of glaucoma, as shown by the reduced incidence of optic nerve degeneration, prevention of RGC soma and axonal loss and retinal nerve fiber layer thinning and preserved visual function $[247,248]$. In a crossover, randomized clinical trial involving 57 glaucoma patients, oral vitamin $\mathrm{B}_{3}$ supplementation for 6 weeks at $1.5 \mathrm{~g} /$ day, then for 6 weeks at $3.0 \mathrm{~g} /$ day, improved RGC function, but without affecting the IOP and RNFL thickness [249].

Table 2. Clinical trials evaluating natural products for glaucoma treatment.

\begin{tabular}{|c|c|c|c|c|}
\hline Natural Products & Subjects & Treatment Regime & Clinical Findings & References \\
\hline \multirow{5}{*}{ Ginkgo biloba } & POAG patients & $\begin{array}{l}120 \mathrm{mg} \text { GB extract, } 1 \text { tablet } \\
\text { daily, } 6 \text { months }\end{array}$ & $\begin{array}{l}\text { Lower rate of single-stranded } \\
\text { DNA breaks in circulating } \\
\text { leukocytes (vs. untreated } \\
\text { patients, } p<0.001 \text { ) }\end{array}$ & [97] \\
\hline & NTG patients & $\begin{array}{l}80 \text { mg GB extract, } 2 \text { tablets } \\
\text { daily, } 4 \text { years }\end{array}$ & $\begin{array}{l}\text { No effect on IOP (vs. } \\
\text { pre-treatment, } p=0.509) \\
\text { Slowed visual field damage } \\
\text { progression }(p<0.001)\end{array}$ & [98] \\
\hline & NTG patients & $\begin{array}{l}80 \mathrm{mg} \text { GB extract, } 2 \text { tablets } \\
\text { daily, } 2 \text { years }\end{array}$ & $\begin{array}{l}\text { Improved HVF deviation (vs. } \\
\text { untreated patients, } p=0.002 \text { ) }\end{array}$ & [99] \\
\hline & NTG patients & $\begin{array}{l}80 \text { mg GB extract, } 2 \text { tablets } \\
\text { daily, } 4 \text { weeks }\end{array}$ & $\begin{array}{l}\text { Increased ocular blood flow, } \\
\text { volume and velocity (vs. } \\
\text { placebo-treated patients, } \\
p<0.03 \text { ) }\end{array}$ & [100] \\
\hline & Healthy subjects & $\begin{array}{l}120 \text { mg GB extract, } 1 \text { tablet } \\
\text { daily, } 4 \text { weeks }\end{array}$ & $\begin{array}{l}\text { Increased radial peripapillary } \\
\text { capillary vascular density (vs. } \\
\text { pre-treatment, } p<0.021 \text { ) }\end{array}$ & [101] \\
\hline Forskolin & POAG patients & $\begin{array}{l}\text { Forskolin } 1 \% w / v \text { aqueous } \\
\text { solution eye drops, } \\
2 \text { drops thrice a day, } \\
4 \text { weeks }\end{array}$ & $\begin{array}{l}\text { Reduced IOP (vs. timolol-treated } \\
\text { patients, } p<0.05 \text { ) } \\
\text { No adverse events }\end{array}$ & [117] \\
\hline Erigeron breviscapus & POAG patients & $\begin{array}{l}\text { E. breviscapus extract, } \\
2 \text { tablets, } 3 \text { times daily, } \\
6 \text { months }\end{array}$ & $\begin{array}{l}\text { No obvious adverse effects } \\
\text { Decreased mean defect (vs. } \\
\text { pre-treatment, } p<0.01) \\
\text { Increased mean sensitivity } \\
(p<0.01)\end{array}$ & [122] \\
\hline Saffron & POAG patients & $\begin{array}{l}\text { Aqueous saffron extract, } \\
30 \mathrm{mg} \text { daily, } 4 \text { weeks }\end{array}$ & $\begin{array}{l}\text { Reduced IOP (vs. pre-treatment, } \\
p=0.0046 \text { ) } \\
\text { No obvious adverse effects }\end{array}$ & [160] \\
\hline
\end{tabular}


Table 2. Cont.

\begin{tabular}{|c|c|c|c|c|}
\hline Natural Products & Subjects & Treatment Regime & Clinical Findings & References \\
\hline \multirow[t]{3}{*}{ Ginseng } & Glaucoma patients & $\begin{array}{l}\text { Korean red ginseng, } 3 \mathrm{~g} \\
\text { daily, } 4 \text { weeks }\end{array}$ & $\begin{array}{l}\text { Improved daytime contrast } \\
\text { sensitivity (vs. pre-treatment, } \\
p=0.004) \text { and ocular pain } \\
(p<0.001)\end{array}$ & [186] \\
\hline & Glaucoma patients & $\begin{array}{l}\text { Korean red ginseng, } 3 \mathrm{~g} \\
\text { daily, } 8 \text { weeks }\end{array}$ & $\begin{array}{l}\text { Improved tear film stability and } \\
\text { total OSDI score (vs. } \\
\text { placebo-treated patients, } \\
p<0.01 \text { ) }\end{array}$ & [187] \\
\hline & OAG patients & $\begin{array}{l}\text { Korean red ginseng, } 1.5 \mathrm{~g} \text {, } \\
3 \text { times daily, } 12 \text { weeks }\end{array}$ & $\begin{array}{l}\text { Improved retinal peripapillary } \\
\text { blood flow in the temporal } \\
\text { peripapillary region (vs. } \\
\text { pre-treatment, } p=0.005 \text { ) } \\
\text { No changes in blood pressure, } \\
\text { heart rate, IOP and visual } \\
\text { field indices }\end{array}$ & [188] \\
\hline \multirow[t]{2}{*}{ Marijuana } & Glaucoma patients & $\begin{array}{l}\text { Marijuana smoking, } \\
\text { single dose }\end{array}$ & $\begin{array}{l}\text { Reduced IOP (vs. } \\
\text { placebo-treated patients, } p \text { value } \\
\text { not defined) } \\
\text { Increased heart rate }\end{array}$ & [195] \\
\hline & Healthy subjects & $\begin{array}{l}\text { Marijuana smoking, } \\
\text { single dose }\end{array}$ & $\begin{array}{l}\text { Reduced IOP (vs. pre-treatment, } \\
p<0.01 \text { ) } \\
\text { No effect on systemic } \\
\text { blood pressure }\end{array}$ & [196] \\
\hline \multirow[t]{5}{*}{ Anthocyanins } & NTG patients & $\begin{array}{l}60 \mathrm{mg}, 2 \text { tablets daily, } \\
2 \text { years }\end{array}$ & $\begin{array}{l}\text { Improved best-corrected visual } \\
\text { acuity (vs. untreated patients, } \\
p=0.008) \text {, and HVF } \\
\text { deviation }(p=0.001)\end{array}$ & [99] \\
\hline & OAG patients & $\begin{array}{l}50 \mathrm{mg} \text { black currant } \\
\text { anthocyanins daily, } 2 \text { years }\end{array}$ & $\begin{array}{l}\text { Increased ocular blood flows (vs. } \\
\text { placebo-treated patients, } p=0.01 \text { ) } \\
\text { Improved visual field damage } \\
\text { progression }(p=0.039)\end{array}$ & [204] \\
\hline & OAG patients & $\begin{array}{l}50 \text { mg black currant } \\
\text { anthocyanins daily, }\end{array}$ & $\begin{array}{l}\text { Reduced IOP (vs. pre-treatment, } \\
p=0.027 \text { ) }\end{array}$ & [205] \\
\hline & & 24 months & $\begin{array}{l}\text { Improved HVF deviation } \\
(p=0.017) \\
\text { No changes in systemic blood } \\
\text { pressure or pulse rates }\end{array}$ & \\
\hline & OAG patients & $\begin{array}{l}50 \text { mg black currant } \\
\text { anthocyanins daily, } \\
24 \text { months }\end{array}$ & $\begin{array}{l}\text { Normalized serum ET-1 } \\
\text { concentrations (vs. healthy } \\
\text { subjects, } p<0.05 \text { ) } \\
\text { No changes in advanced } \\
\text { oxidation protein products, and } \\
\text { antioxidative activities }\end{array}$ & [206] \\
\hline $\begin{array}{l}\text { Hesperidin, crocetin and } \\
\text { Tamarindus indica }\end{array}$ & NTG patients & $\begin{array}{l}\text { Food supplement } \\
\text { containing hesperidin } \\
(50 \mathrm{mg}), \text { crocetin }(7.5 \mathrm{mg}) \\
\text { and T. indica }(25 \mathrm{mg}), \\
4 \text { tablets twice a day, } \\
8 \text { weeks }\end{array}$ & $\begin{array}{l}\text { Reduced 8-OHdG level in } \\
\text { high-oxidative stress patients (vs. } \\
\text { pre-treatment, } p<0.01 \text { ) } \\
\text { Elevated BAP in high-oxidative } \\
\text { stress patients }(p=0.03 \text { ) }\end{array}$ & [222] \\
\hline \multirow[t]{4}{*}{ Caffeine } & POAG patients & $\begin{array}{l}\text { Coffee containing } 1.3 \% \\
\text { caffeine (104 mg caffeine), } \\
\text { single dose }\end{array}$ & $\begin{array}{l}\text { Reduced IOP (vs. } \\
\text { water-drinking patients, } \\
p=0.012) \\
\text { Reduced IOP fluctuation } \\
(p=0.013)\end{array}$ & {$[228]$} \\
\hline & POAG patients & $\begin{array}{l}1 \% \text { caffeine eye drop, } \\
\text { thrice a day, } 1 \text { week }\end{array}$ & $\begin{array}{l}\text { No effect on IOP (vs. } \\
\text { pre-treatment, } p>0.05)\end{array}$ & [229] \\
\hline & Healthy subjects & $\begin{array}{l}\text { Caffeine capsule, } 4 \mathrm{mg} / \mathrm{kg} \text {, } \\
\text { single dose }\end{array}$ & $\begin{array}{l}\text { Increased IOP (vs. pre-treatment, } \\
p<0.05 \text { ) }\end{array}$ & [230] \\
\hline & Healthy subjects & $\begin{array}{l}\text { Caffeine capsule, } 4 \mathrm{mg} / \mathrm{kg} \text {, } \\
\text { single dose }\end{array}$ & $\begin{array}{l}\text { Increased IOP (vs. } \\
\text { placebo-treated subjects, } p<0.05) \\
\text { Reduced anterior chamber angle } \\
(p<0.05)\end{array}$ & [231] \\
\hline
\end{tabular}


Table 2. Cont.

\begin{tabular}{|c|c|c|c|c|}
\hline Natural Products & Subjects & Treatment Regime & Clinical Findings & References \\
\hline Coenzyme Q10 & POAG patients & $\begin{array}{l}\text { CoQ10 and vitamin E eye } \\
\text { drop, } 2 \text { drops daily, } \\
12 \text { months }\end{array}$ & $\begin{array}{l}\text { Decreased ERG P50 and VEP } \\
\text { P100 implicit times (vs. } \\
\text { pre-treatment, } p<0.01) \\
\text { Increased PERG P50-N95 and } \\
\text { VEP N75-P100 amplitudes } \\
(p<0.01)\end{array}$ & [242] \\
\hline Vitamin $B_{3}$ & Glaucoma patients & $\begin{array}{l}\text { Vitamin } B_{3} \text { tablet, } \\
1.5 \mathrm{~g} / \text { day } 6 \text { weeks, } \\
\text { followed by } 3.0 \mathrm{~g} / \text { day for } \\
6 \text { weeks }\end{array}$ & $\begin{array}{l}\text { Improved RGC } \\
\text { functions-PhNR Vmax (vs. } \\
\text { placebo-treated patients, } \\
p=0.03), \text { Vmax ratio }(p=0.02) \\
\text { and visual field mean deviation } \\
(p=0.02) \\
\text { No effect on IOP }(p=0.59) \text { and } \\
\text { RNFL thickness }(p=0.11)\end{array}$ & [249] \\
\hline
\end{tabular}

8-OhdG, 8-hydroxydeoxyguanosine; BAP, biological antioxidant potential; ET-1, endothelin-1; HVF, Humphrey visual field; IOP, intraocular pressure; NTG, normal-tension glaucoma; OAG, open-angle glaucoma; OSDI, Ocular Surface Disease Index; PhNR, photopic negative; POAG, primary open-angle glaucoma; PERG, pattern electroretinogram; RGC, retinal ganglion cell; RNFL, retinal nerve fiber layer.

Previous studies have reported that serum vitamin D levels are significantly lower in glaucoma patients as compared to healthy subjects $[250,251]$. Additionally, the presence of polymorphisms in vitamin $D$ receptors, e.g., the BsmI ' $B$ ' allele and TaqI ' $t$ ' allele, was shown to be a relevant risk factor in the development of POAG [251]. Vitamin D deficiency subjects were reported to have higher, although not significant, IOP values compared to healthy individuals [252]. Treatment with $1 \alpha, 25$-dihydroxyvitamin $\mathrm{D}_{3}$ and its analog 2-methylene-19-nor-(20S)-1 $\alpha$,25-dihydroxyvitamin $\mathrm{D}_{3}$ through eye drops reduced the IOP in normal monkeys [253]. D2 mice treated with $1 \mu \mathrm{g} / \mathrm{kg}$ of $1 \alpha, 25$-dihydroxyvitamin $\mathrm{D}_{3}$, intraperitoneally for 5 weeks, showed improved RGC function (increased PERG and FERG amplitudes) and reduced RGC death, compared to vehicle-treated controls [254]. Additionally, the same study also reported decreased microglial and astrocyte activation, reduced inflammatory cytokines (IL- $1 \beta$ and -6, IFN- $\gamma$ and CCL-3) and increased expression of neuroprotective factors (BDNF, VEGF-A and PlGF) in the 1 $\alpha, 25$-dihydroxyvitamin $\mathrm{D}_{3}$ treatment group [254].

Induced OHT rats fed with a vitamin E-supplemented diet showed no difference in RGC cell death, compared to normal diet-treated rats [255]. However, the same study demonstrated that dietary vitamin E deficiency aggravated RGC apoptosis following induced OHT, which was found to be related to the increased level of lipid peroxidation [255]. In contrast, both topical and systemic $\alpha$-tocopherol administration preserved the RGC numbers and retinal morphology in an optic nerve crush rat model [256]. 
Table 3. Preclinical studies on natural products used for glaucoma treatment and their mechanism of action.

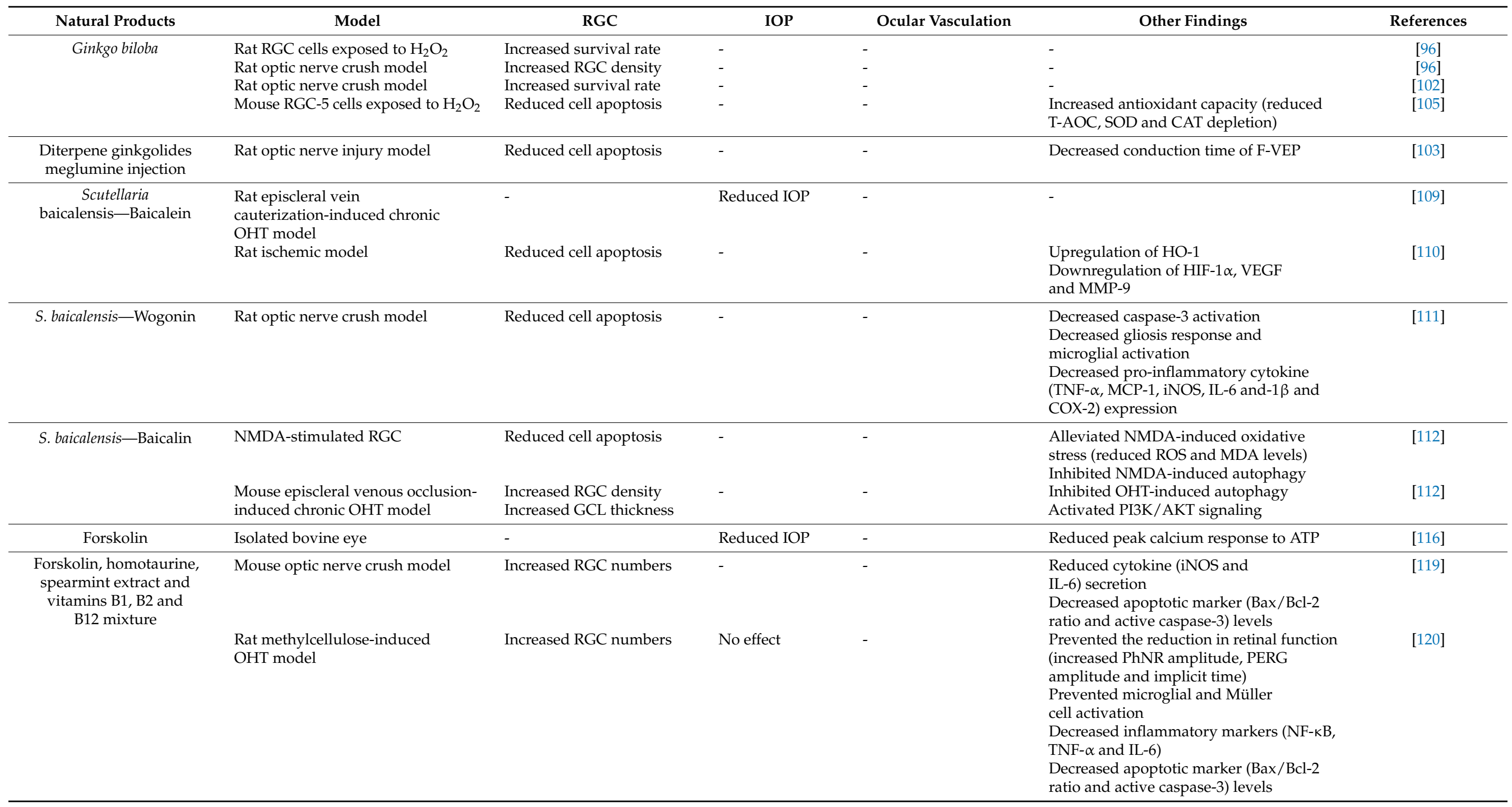


Table 3. Cont.

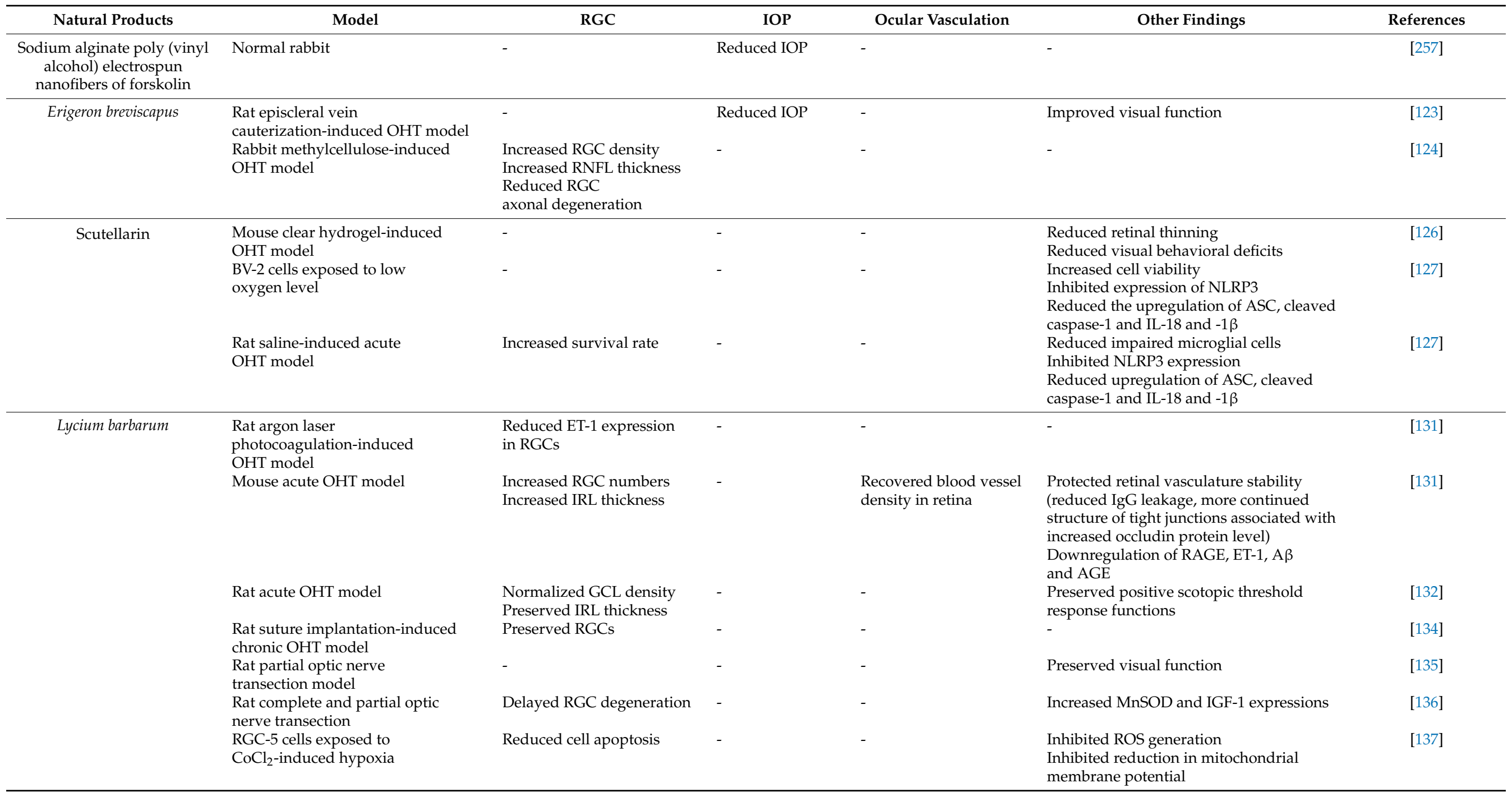


Table 3. Cont.

\begin{tabular}{|c|c|c|c|c|c|c|}
\hline Natural Products & Model & RGC & IOP & Ocular Vasculation & Other Findings & References \\
\hline & Human TM cells exposed to $\mathrm{H}_{2} \mathrm{O}_{2}$ & - & - & - & $\begin{array}{l}\text { Promoted cell viability } \\
\text { Reduced apoptosis } \\
\text { Reduced cleaved caspase-3/-9 and } \\
\text { ROS levels }\end{array}$ & [138] \\
\hline & $\begin{array}{l}\text { Rat partial optic nerve } \\
\text { transection model }\end{array}$ & $\begin{array}{l}\text { Delayed secondary } \\
\text { degeneration of RGCs }\end{array}$ & - & - & $\begin{array}{l}\text { Promoted M2 polarization of } \\
\text { microglia/macrophages } \\
\text { Downregulated autophagy level }\end{array}$ & [139] \\
\hline & $\begin{array}{l}\text { PC12 cells exposed to } \\
\text { hydrostatic pressures }\end{array}$ & - & - & - & $\begin{array}{l}\text { Reduced ANGPTL7, MMP-2 and -9, } \\
\text { collagen I and TGF- } \beta \text { expressions }\end{array}$ & [141] \\
\hline & Mouse retinal I/R injury model & $\begin{array}{l}\text { Retinal cellular organization } \\
\text { remained normal } \\
\text { Fewer pyknotic nuclei in } \\
\text { GCL and INL }\end{array}$ & - & - & Reduced glial activation & [144] \\
\hline & Rat retinal I/R injury model & $\begin{array}{l}\text { Reduced apoptosis in GCL } \\
\text { and INL }\end{array}$ & - & 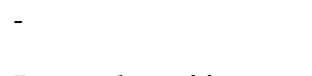 & $\begin{array}{l}\text { Increased Nrf2 nuclear accumulation } \\
\text { Increased HO-1 expression }\end{array}$ & [145] \\
\hline & $\begin{array}{l}\text { Rat saline-induced acute } \\
\text { OHT model }\end{array}$ & $\begin{array}{l}\text { Downregulation of APP } \\
\text { and RAGE expressions }\end{array}$ & - & $\begin{array}{l}\text { Reverse loss of function } \\
\text { of astrocyte endfeet } \\
\text { around blood vessels }\end{array}$ & $\begin{array}{l}\text { Reduced numbers of astrocytes } \\
\text { and microglia } \\
\text { Decreased glutamine toxicity in astrocytes } \\
\text { (downregulation of glutamine synthetase) }\end{array}$ & [146] \\
\hline & Rat retinal I/R injury model & - & - & - & $\begin{array}{l}\text { Preserved retinal thickness } \\
\text { Increased antioxidant levels (GSSH + GSH, } \\
\text { SOD and CAT) } \\
\text { Reduced MDA level }\end{array}$ & [146] \\
\hline \multirow[t]{3}{*}{ Diospyros kaki } & $\begin{array}{l}\text { Mouse microbead-induced OHT } \\
\text { model, and D2 mouse }\end{array}$ & Reduced RGC loss & Reduced IOP & - & Increased sGC $\alpha-1$ expression & [149] \\
\hline & RGC- 5 cells exposed to glutamate & Increased cell viability & - & - & $\begin{array}{l}\text { Decreased apoptotic protein levels (poly } \\
\text { (ADP-ribose) polymerase, p53 and } \\
\text { cleaved caspase-3) } \\
\text { Increased antioxidant-associated protein } \\
\text { expression levels (SOD, GST and GPX) }\end{array}$ & [150] \\
\hline & $\begin{array}{l}\text { Mouse partial optic nerve } \\
\text { crush model }\end{array}$ & Reduced RGC death & - & - & - & [150] \\
\hline \multirow[t]{3}{*}{ T. wilfordii-Triptolide } & D2 mouse & Improved RGC survival & No effect & - & Suppressed microglia activation & [153] \\
\hline & $\begin{array}{l}\text { Angle photocoagulation-induced } \\
\text { chronic glaucoma rat model }\end{array}$ & Improved RGC survival & - & - & $\begin{array}{l}\text { Reduced microglia count } \\
\text { Reduced TNF- } \alpha \text { expression }\end{array}$ & [154] \\
\hline & Mouse optic nerve crush model & Improved RGC survival & - & - & $\begin{array}{l}\text { Reduced TNF- } \alpha \text { expression } \\
\text { Inhibited nuclear translocation of NF- } \mathrm{KB}\end{array}$ & [155] \\
\hline \multirow[t]{2}{*}{ T. wilfordii-celastrol } & Mouse optic nerve crush model & Improved RGC survival & - & - & Reduced TNF- $\alpha$ expression & [156] \\
\hline & $\begin{array}{l}\text { Rat trabecular laser } \\
\text { photocoagulation model }\end{array}$ & Improved RGC survival & - & - & - & [157] \\
\hline
\end{tabular}


Table 3. Cont.

\begin{tabular}{|c|c|c|c|c|c|c|}
\hline Natural Products & Model & RGC & IOP & Ocular Vasculation & Other Findings & References \\
\hline Crocus sativus $\mathrm{L}$. & Mouse laser-induced OHT model & Prevented RGC death & - & - & $\begin{array}{l}\text { Decreased microglial numbers and } \\
\text { their activation } \\
\text { Partially reversed downregulation } \\
\text { of P2RY12 }\end{array}$ & [159] \\
\hline \multirow[t]{2}{*}{ C. sativus-Crocin } & Rat retinal I/R injury model & Increased RGC survival & - & - & $\begin{array}{l}\text { Inhibited retinal thinning } \\
\text { Decreased cleaved caspase- } 3 \text { and } p \text {-ERK } \\
\text { protein expressions } \\
\text { Increased GSH and T-SOD activities } \\
\text { Decreased ROS and MDA levels }\end{array}$ & [162] \\
\hline & RGC- 5 cells exposed to $\mathrm{H}_{2} \mathrm{O}_{2}$ & $\begin{array}{l}\text { Protected RGCs } \\
\text { from apoptosis } \\
\text { Enhanced cell viability }\end{array}$ & - & - & $\begin{array}{l}\text { Decreased LDH release } \\
\text { Decreased ROS levels } \\
\text { Increased } \triangle \Psi \mathrm{m} \\
\text { Downregulated Bax and cytochrome c } \\
\text { protein expressions } \\
\text { Promoted Bcl-2 protein expression } \\
\text { Activated NF-KB }\end{array}$ & [164] \\
\hline C. sativus-Crocetin & $\begin{array}{l}\text { Mouse NMDA-induced retinal } \\
\text { injury model }\end{array}$ & Increased GCL density & - & - & $\begin{array}{l}\text { Reduced TUNEL-positive cells } \\
\text { Inhibited activated caspase- } 3 /-7 \\
\text { Increased cleaved caspsase-3 expression }\end{array}$ & [165] \\
\hline \multirow[t]{5}{*}{ Curcumin } & BV-2 cells exposed to $\mathrm{H}_{2} \mathrm{O}_{2}$ & - & - & - & $\begin{array}{l}\text { Increased cell viability } \\
\text { Decreased ROS and apoptosis } \\
\text { Downregulated caspase-3, cytochrome c } \\
\text { and Bax } \\
\text { Upregulated Bcl-2 }\end{array}$ & [169] \\
\hline & Rat episcleral vein cauterization & Prevented RGC loss & - & - & $\begin{array}{l}\text { Downregulated caspase-3, cytochrome c } \\
\text { and Bax } \\
\text { Upregulated Bcl-2 }\end{array}$ & [169] \\
\hline & Ex vivo optic nerve cut model & $\begin{array}{l}\text { Increased RGC survival } \\
\text { Preserved retinal thickness }\end{array}$ & & & $\begin{array}{l}\text { Prevented alterations in apoptotic cascades } \\
\text { and MAPK and SUMO- } 1 \text { pathways }\end{array}$ & [170] \\
\hline & Rat retinal I/R injury model & & - & - & Prevented retinal damage & [171] \\
\hline & Rat retinal I/R injury model & $\begin{array}{l}\text { Inhibited GCL cell loss } \\
\text { Reduced cell apoptosis }\end{array}$ & & & $\begin{array}{l}\text { Inhibited retinal capillary degeneration } \\
\text { Inhibited upregulation of MCP-1, IKK } \alpha \text {, } \\
p \text {-IкB } \alpha \text { and } p \text {-STAT3 (Tyr), and } \\
\text { downregulation of } \beta \text {-tubulin II }\end{array}$ & {$[172]$} \\
\hline
\end{tabular}


Table 3. Cont.

\begin{tabular}{|c|c|c|c|c|c|c|}
\hline Natural Products & Model & RGC & IOP & Ocular Vasculation & Other Findings & References \\
\hline & $\begin{array}{l}\text { Primary porcine TM cells exposed } \\
\text { to } \mathrm{H}_{2} \mathrm{O}_{2}\end{array}$ & - & - & - & $\begin{array}{l}\text { Prevented cell death } \\
\text { Reduced ROS production } \\
\text { Inhibited pro-inflammatory factors (IL-6, } \\
-1 \alpha \text { and }-8 \text { and ELAM-1) } \\
\text { Decreased SA- } \beta \text {-gal activity } \\
\text { Reduced carbonylated proteins and } \\
\text { apoptotic cell numbers }\end{array}$ & [173] \\
\hline & $\begin{array}{l}\text { Primary porcine TM cells exposed } \\
\text { to } \mathrm{H}_{2} \mathrm{O}_{2}\end{array}$ & 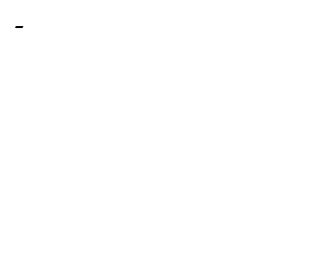 & 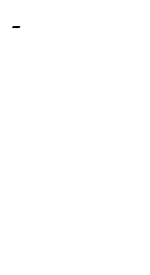 & - & $\begin{array}{l}\text { Reduced ROS level } \\
\text { Reduced apoptosis } \\
\text { Upregulated Bcl-2 } \\
\text { Downregulated Bax and activated } \\
\text { caspase- } 3 \text { levels } \\
\text { Reduced Nrf2, HO-1 and } \\
\text { NQO1 expressions } \\
\text { Increased Keap1 expression }\end{array}$ & {$[174]$} \\
\hline & $\begin{array}{l}\text { Rat partial optic nerve } \\
\text { transection model }\end{array}$ & $\begin{array}{l}\text { Improved RGC } \\
\text { density ratio }\end{array}$ & No effect & - & - & [258] \\
\hline & Human TM cells exposed to $\mathrm{H}_{2} \mathrm{O}_{2}$ & - & - & - & $\begin{array}{l}\text { Reduced TNF and IL- } 1 \alpha \text { and }-6 \text { expression } \\
\text { Reduced mitochondrial ROS production } \\
\text { Reduced cleaved caspase- } 3 \text { proteins } \\
\text { Reduced TUNEL-positive cells }\end{array}$ & [259] \\
\hline Green tea & $\begin{array}{l}\text { Rat LPS-induced retinal } \\
\text { inflammation model }\end{array}$ & - & - & - & $\begin{array}{l}\text { Suppressed activated microglia, astrocytes } \\
\text { and Müller glia } \\
\text { Reduced pro-inflammatory cytokine } \\
\text { expressions (IL- } 1 \beta \text { and }-6 \text { and TNF- } \alpha \text { in } \\
\text { retina and vitreous humor) }\end{array}$ & [177] \\
\hline \multirow[t]{4}{*}{ Green tea-EGCG } & $\begin{array}{l}\text { Rat saline-induced acute } \\
\text { OHT model }\end{array}$ & 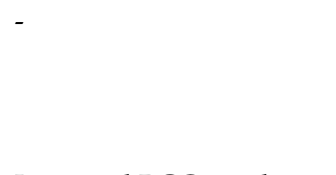 & - & - & $\begin{array}{l}\text { Decreased inflammation-associated } \\
\text { cytokine levels } \\
\text { Decreased the proliferation rate of } \mathrm{T} \\
\text { lymphocyte cells } \\
\text { Reduced IкB } \alpha \text { and p } 65 \text { phosphorylation }\end{array}$ & [179] \\
\hline & $\begin{array}{l}\text { Mouse microbead-induced } \\
\text { OHT model }\end{array}$ & Increased RGC numbers & No effect & - & - & [180] \\
\hline & Rat optic nerve crush model & Increase RGC density & - & - & Increased NF-L protein expression & [181] \\
\hline & Rabbit retinal I/R injury model & $\begin{array}{l}\text { Preserved organization of } \\
\text { GCL, IPL and INL }\end{array}$ & - & - & $\begin{array}{l}\text { Reduced retinal gliosis } \\
\text { Reduced MDA level }\end{array}$ & [182] \\
\hline
\end{tabular}


Table 3. Cont.

\begin{tabular}{|c|c|c|c|c|c|c|}
\hline Natural Products & Model & RGC & IOP & Ocular Vasculation & Other Findings & References \\
\hline & $\begin{array}{l}\text { Rat NMDA-induced } \\
\text { excitotoxicity model }\end{array}$ & Increased GCL cell density & - & - & - & [183] \\
\hline \multirow[t]{3}{*}{ Ginseng } & Rat optic nerve crush injury model & $\begin{array}{l}\text { Increased cell survival } \\
\text { Reduced cell apoptosis }\end{array}$ & - & - & $\begin{array}{l}\text { Increased Bcl-2/Bax protein ratio } \\
\text { Decreased c-Jun, P-c-Jun and P-JNK } \\
\text { protein expressions }\end{array}$ & [190] \\
\hline & $\begin{array}{l}\text { Rabbit ultrasound-targeted } \\
\text { microbubble optic nerve } \\
\text { injury model }\end{array}$ & Reduced RGC damage & Reduced IOP & - & $\begin{array}{l}\text { Reduced oxidative stress level } \\
\text { Reduced MDA and NO levels } \\
\text { Increased SOD level }\end{array}$ & [191] \\
\hline & $\begin{array}{l}\text { RGC- } 5 \text { cells exposed to } \mathrm{CoCl}_{2} \\
\text { or } \mathrm{H}_{2} \mathrm{O}_{2}\end{array}$ & Reduced cell apoptosis & - & - & $\begin{array}{l}\text { Reduced cleaved caspase- } 3 \text { and } \\
-9 \text { expressions }\end{array}$ & [192] \\
\hline \multirow{2}{*}{ Marijuana- $-\Delta^{9}-\mathrm{THC}$} & Normal dogs & - & Reduced IOP & - & No effect on aqueous humor flow rate & [197] \\
\hline & Normal rabbit & - & Reduced IOP & - & - & [198] \\
\hline Marijuana- $\Delta^{8}-\mathrm{THC}$ & $\begin{array}{l}\text { Rabbit chymotrypsin-induced } \\
\text { OHT model }\end{array}$ & - & Reduced IOP & - & - & [199] \\
\hline Marijuana & Rat retinal I/R injury model & Reduced RGC damage & - & - & - & [201] \\
\hline Anthocyanins & $\begin{array}{l}\text { RGC- } 5 \text { cells exposed to } \mathrm{H}_{2} \mathrm{O}_{2} \\
\text { Mouse optic nerve crush model }\end{array}$ & $\begin{array}{l}\text { Increased survival rate } \\
\text { Increased survival rate }\end{array}$ & $\begin{array}{l}- \\
-\end{array}$ & - & $\begin{array}{l}\text { - } \\
\text { Increased Grp78 and Grp94 levels }\end{array}$ & $\begin{array}{l}{[207]} \\
{[208]}\end{array}$ \\
\hline \multirow[t]{6}{*}{ Resveratrol } & Glaucomatous human TM cells & - & - & - & $\begin{array}{l}\text { Increased eNOS and NO levels } \\
\text { Decreased iNOS expressions } \\
\text { Increased IL- } 1 \alpha \text { level with low dose } \\
\text { Decreased IL- } 1 \alpha \text { level with high dose }\end{array}$ & [211] \\
\hline & $\begin{array}{l}\text { Rat hyaluronic acid-induced chronic } \\
\text { OHT model }\end{array}$ & Preserved RGC numbers & No effect & - & - & [212] \\
\hline & $\begin{array}{l}\text { Mouse microbead-induced } \\
\text { OHT model }\end{array}$ & Preserved RGC numbers & - & - & $\begin{array}{l}\text { Decreased ROS generation and } \\
\text { acetyl-p53 expression } \\
\text { Upregulated BDNF and TrkB expressions }\end{array}$ & [213] \\
\hline & RGC- 5 cells exposed to $\mathrm{H}_{2} \mathrm{O}_{2}$ & Increased cell viability & - & - & $\begin{array}{l}\text { Reduced expressions of cleaved caspase- } 3 \\
\text { and }-9 \\
\text { Reduced ROS production } \\
\text { Reduced loss of mitochondrial membrane } \\
\text { potential and } p \text {-p } 38, p \text {-ERK and } \\
p \text {-JNK expressions } \\
\text { Promoted SOD, CAT and GSH activities }\end{array}$ & [214] \\
\hline & Mouse retinal I/R injury model & $\begin{array}{l}\text { Ameliorated retinal } \\
\text { thickness damage } \\
\text { Increased RGC numbers }\end{array}$ & - & - & $\begin{array}{l}\text { Downregulated mitochondrial } \\
\text { apoptosis-related proteins (Bax and } \\
\text { cleaved caspase-3) } \\
\text { Increased Bcl- } 2 \text { expression }\end{array}$ & [215] \\
\hline & Mouse retinal I/R injury model & $\begin{array}{l}\text { Reduced RGC loss } \\
\text { Reduced retinal damage }\end{array}$ & - & - & $\begin{array}{l}\text { Reduced TUNEL staining } \\
\text { Reduced Bax and cleaved caspase- } 3 \text { levels }\end{array}$ & [216] \\
\hline
\end{tabular}


Table 3. Cont.

\begin{tabular}{|c|c|c|c|c|c|c|}
\hline Natural Products & Model & RGC & IOP & Ocular Vasculation & Other Findings & References \\
\hline & Mouse retinal I/R injury model & Reduced RGC loss & - & - & $\begin{array}{l}\text { Reduced Bcl-2, Bax, caspase-3, GFAP, } \\
\text { COX-2 and iNOS expressions }\end{array}$ & [217] \\
\hline & $\begin{array}{l}\text { Rat superparamagnetic iron } \\
\text { oxide-induced chronic OHT model }\end{array}$ & $\begin{array}{l}\text { No effect on GCL density } \\
\text { Decreased cell apoptosis }\end{array}$ & No effect & - & $\begin{array}{l}\text { Improved retinal morphology } \\
\text { Improved expressions of proteins involved } \\
\text { in mitochondrial biogenesis and dynamics }\end{array}$ & [218] \\
\hline & $\begin{array}{l}\text { RGC- } 5 \text { cells exposed to } \\
\text { elevated pressure }\end{array}$ & Decreased cell apoptosis & - & - & $\begin{array}{l}\text { Decreased mitochondrial membrane } \\
\text { potential depolarization }\end{array}$ & [218] \\
\hline & & & & & Decreased ROS production & \\
\hline & & & & & $\begin{array}{l}\text { Upregulated expressions of proteins } \\
\text { involved in mitochondrial biogenesis } \\
\text { and dynamics }\end{array}$ & \\
\hline & Mouse retinal I/R injury model & $\begin{array}{l}\text { Decreased cell apoptosis } \\
\text { Restored retina thickness }\end{array}$ & & & $\begin{array}{l}\text { Increased Opa } 1 \text { expression, and long Opa1 } \\
\text { isoform-to-short Opa } 1 \text { isoform ratios }\end{array}$ & [219] \\
\hline & Normal rabbit & - & Reduced IOP & - & - & [260] \\
\hline \multirow[t]{4}{*}{ Hesperidin } & $\begin{array}{l}\text { Rat dextrose- or prednisolone } \\
\text { acetate-induced OHT model }\end{array}$ & - & Reduced IOP & - & $\begin{array}{l}\text { Increased glutathione } \\
\text { Reduced morphological alteration in } \\
\text { ciliary bodies }\end{array}$ & [223] \\
\hline & $\begin{array}{l}\text { Mouse NMDA-induced retinal } \\
\text { injury model }\end{array}$ & 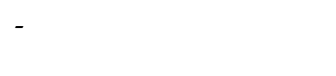 & - & - & $\begin{array}{l}\text { Reduced inflammatory cytokine (TNF- } \alpha \text {, } \\
\text { IL- } 1 \mathrm{~b} \text { and }-6 \text { and MCP- } 1 \text { ) expressions }\end{array}$ & [224] \\
\hline & $\begin{array}{l}\text { Mouse NMDA-induced retinal } \\
\text { injury model }\end{array}$ & $\begin{array}{l}\text { Prevented reductions in } \\
\text { RGC markers } \\
\text { Prevented RGC death }\end{array}$ & - & - & $\begin{array}{l}\text { Reduced calpain activation, ROS } \\
\text { generation and TNF- } \alpha \text { gene expression } \\
\text { Improved electrophysiological function } \\
\text { and visual function }\end{array}$ & [225] \\
\hline & $\begin{array}{l}\text { Rat hypobaric hypoxia-induced } \\
\text { retinal injury model }\end{array}$ & - & - & - & $\begin{array}{l}\text { Enhanced Nrf2 and HO- } 1 \text { activation } \\
\text { Attenuated apoptotic caspase levels } \\
\text { Reduced Bax and preserved } \\
\text { Bcl-2 expressions } \\
\text { Downregulated PARP1 expression } \\
\text { Upregulated CNTF expression }\end{array}$ & [226] \\
\hline \multirow[t]{2}{*}{ Caffeine } & Rat laser-induced OHT model & Increased survival rate & Reduced IOP & - & $\begin{array}{l}\text { Downregulated TNF and IL-1 } \beta \text { mRNA } \\
\text { and protein levels } \\
\text { Suppressed microglia activation } \\
\text { (downregulated MHC-II, TSPO, CD11b } \\
\text { and TREM2 expressions) }\end{array}$ & [234] \\
\hline & Rat retinal I/R injury model & - & - & - & $\begin{array}{l}\text { Reduced microglial activation at } 7 \text { days } \\
\text { post-injury (reduced Iba1 and MHC-II } \\
\text { cells; reduced TSPO and MHC-II } \\
\text { mRNA levels) } \\
\text { Reduced TUNEL-positive cells }\end{array}$ & [235] \\
\hline
\end{tabular}


Table 3. Cont.

\begin{tabular}{|c|c|c|c|c|c|c|}
\hline \multirow[t]{8}{*}{ Natural Products } & Model & RGC & IOP & Ocular Vasculation & Other Findings & References \\
\hline & $\begin{array}{l}\text { Human retinal pigment epithelial } \\
\text { cells exposed to LPS }\end{array}$ & - & - & - & $\begin{array}{l}\text { Reduced LPS-induced inflammatory } \\
\text { cytokines (TNF- } \alpha \text {, IL- } 1 \beta \text { and - } 6 \text { ) }\end{array}$ & [236] \\
\hline & & & & & Restored BDNF expression & \\
\hline & & & & & $\begin{array}{l}\text { Reduced } p \text {-NF-kB p65 } \\
\text { nuclear translocation }\end{array}$ & \\
\hline & & & & & Restored blood-retinal barrier (increased & \\
\hline & & & & & transepithelial electrical resistance value & \\
\hline & Mouse retinal $\mathrm{I} / \mathrm{R}$ iniury model & & & & $\begin{array}{l}\text { and ZO-1 tight junction expression) } \\
\text { Increased PERG amplitude }\end{array}$ & [236] \\
\hline & Mouse retinal $1 / K$ injury model & - & - & - & Reduced IL-6 mRNA expression & {$[236]$} \\
\hline \multirow[t]{15}{*}{ Coenzyme Q10 } & Mouse retinal ischemia model & Promoted RGC survival & - & - & Prevented upregulation of SOD2 and & [239] \\
\hline & & & & & HO-1 protein expression & \\
\hline & & & & & Blocked activation of astrocytes and & \\
\hline & & & & & microglial cells & \\
\hline & & & & & $\begin{array}{l}\text { Blocked apoptosis by decreasing caspase- } 3 \\
\text { protein expression }\end{array}$ & \\
\hline & & & & & Decreased Bax protein expression & \\
\hline & & & & & Preserved Tfam protein expression & \\
\hline & D2-Gpnmb $b^{+}$mice & Promoted RGC survival & - & - & Preserved axons in the ONH & [240] \\
\hline & & & & & Inhibited astrocytes activation & \\
\hline & & & & & SOD2 and HO1 protein expressions & \\
\hline & & & & & Decreased Bax protein expression & \\
\hline & & & & & Preserved mtDNA content and & \\
\hline & & & & & Tfam/OXPHOS complex IV & \\
\hline & Rat chronic OHT model & $\begin{array}{l}\text { Prevented RGC apoptosis } \\
\text { and RGC loss }\end{array}$ & No effect & - & - & [241] \\
\hline & $\begin{array}{l}\text { Rat mechanic optic nerve } \\
\text { injury model }\end{array}$ & Increased RGC numbers & - & - & $\begin{array}{l}\text { Reduced activation of astroglia and } \\
\text { microglial cells } \\
\text { Increased Bcl-xL protein expression }\end{array}$ & [243] \\
\hline \multirow[t]{9}{*}{ Vitamin $B_{3}$} & D2-Gpnmb ${ }^{+}$mouse & Prevented RGC loss & Reduced IOP at & - & Prevented the decline in NAD levels & [247] \\
\hline & & Prevented RNFL thinning & high dose & & Reduced incidence of optic & \\
\hline & & & & & nerve degeneration & \\
\hline & & & & & Improved PERG amplitude & \\
\hline & & & & & Inhibited formation of & \\
\hline & & & & & dysfunctional mitochondria & \\
\hline & & & & & Decreased PARP activation & \\
\hline & & & & & Reduced DNA damage & \\
\hline & D2 mouse & Increased RCC density & $\ldots$ & _. & Reduced HIF- $1 \alpha$ transcriptional induction & [248] \\
\hline
\end{tabular}


Table 3. Cont.

\begin{tabular}{|c|c|c|c|c|c|c|}
\hline Natural Products & Model & RGC & IOP & Ocular Vasculation & Other Findings & References \\
\hline \multirow[t]{7}{*}{ Vitamin D } & Normal monkeys & - & Reduced IOP & - & - & [253] \\
\hline & D2 mouse & Reduced RGC death & - & - & Improved PERG and FERG amplitudes & [254] \\
\hline & & & & & Increased neuroprotective factor (BDNF, & \\
\hline & & & & & VEGF-A and PlGF) mRNA levels & \\
\hline & & & & & Decreased inflammatory cytokine (IL- $1 \beta$, & \\
\hline & & & & & -6, IFN- $\gamma$ and CCL-3) expressions & \\
\hline & & & & & Decreased NF- $\kappa B$ activation & \\
\hline Vitamin E & Rat optic nerve crush model & Preserved RGC numbers & - & - & - & [256] \\
\hline
\end{tabular}

$\Delta^{9}$-THC, $\Delta$-9-tetrahydrocannabinol; A $\beta$, amyloid beta; AGE, advanced glycation end products; ANGPTL7, angiopoietin-like protein 7; APP, amyloid precursor protein; ASC, caspase recruitment domain; Bax, Bcl-2-like protein 4; Bcl-2, B cell lymphoma 2; CAT, catalase; CNTF, ciliary neurotrophic factor; COX-2, cyclooxygenase; D2, DBA/2J; ELAM-1, endothelial leucocyte adhesion molecule-1; eNOS, endothelial nitric oxide synthase; ET-1, endothelin-1; F-VEP, flash visual evoked potentials; GCL, ganglion cell layer; GPX, glutathione peroxidase; GSH, glutathione; HIF-1 $\alpha$, hypoxia-inducible factor-1 $\alpha$; HO-1, heme oxygenase-1; IGF-1, insulin-like growth factor 1; IL, interleukin; iNOS, inducible nitric oxide synthase; IRL, insulin receptor-like; LDH, lactate dehydrogenase; LPS, lipopolysaccharide; MCP-1, monocyte chemoattractant protein-1; MDA, malondialdehyde; MHC-II, major histocompatibility complex class II; MMP, metalloproteinase; NF-kB, nuclear factor-kappa B; NF-L, neurofilament light chain; NLRP3, NOD-, LRR- and pyrin domain-containing protein 3; NMDA $\mathrm{N}$-methyl-d-aspartate; $\mathrm{Nrf}$ nuclear factor erythroid 2-related factor; $\mathrm{NQO1}, \mathrm{NAD}(\mathrm{P}) \mathrm{H}$-quinone oxidoreductase; $\mathrm{OHT}$; ocular hypertension; $\mathrm{ONH}$, optic nerve head; OPA1, optic atrophy 1; OXPHOS, oxidtive phosphorylation; PARP1, poly [ADP-ribol polymase 1; PERG, pattern ectro 1;OX ROS, rective oxygen species; RAGE, receptor for advanced glycation end products; RGC, retinal ganglion cell; RNFL, retinal nerve fiber layer; sGC $\alpha-1$, soluble guanylate cyclase $\alpha 1$; SOD, superoxide dismutase; T-AOC, total antioxidant capacity coloimetric; TNF- $\alpha$, tumor necrosis factor-alpha; TGF- $\beta$, transforming growth factor-beta; Tfam, mitochondrial transcription factor A; TREM2, triggering receptor expressed on myeloid cells 2; TSPO, translocator protein (18 kDa); VEGF, vascular endothelial growth factor. 


\section{Challenges for Natural Product Application in Glaucoma Treatment}

The WHO has defined guidelines for evaluating the safety and efficacy of natural products, which is important to further supporting the use of CAM in the healthcare system [261]. This guideline provides general principles for both preclinical and clinical studies on evaluating herbal medicines, i.e., quality and preparation of plant materials, and general pharmacological, pharmacodynamic and toxicological analyses. Although the use of crude extracts from whole plants or a particular part of any herbal plant proves to be useful in the treatment of glaucoma, as described in this review, the identification and isolation of an active phytochemical may also be important, especially in the drug development process. Crude extracts contain a wide range of phytochemicals that may work synergistically or individually to provide a polypharmacy effect in the treatment of glaucoma [262]. Similarly, several studies have reported the use of a mixture of molecules to be effective in reducing IOP in POAG patients. Researchers may have difficulty in identifying the exact mechanism or compound responsible for such findings. For instance, oral administration of two tablets per day of a food supplement containing $150 \mathrm{mg}$ of $C$. forskohlii extract (containing $15 \mathrm{mg}$ forskolin), $200 \mathrm{mg}$ of rutin, $0.7 \mathrm{mg}$ of vitamin B1 and $0.8 \mathrm{mg}$ of vitamin B2 for 30 days contributed to reducing IOP in POAG patients [263]. The same supplementation has also been shown to reduce ocular discomfort in POAG patients due to chronic use of multi-dose eye drops containing preservatives [264], and to prevent IOP spikes after neodymium:YAG laser iridotomy in patients at risk of POAG [265]. Additionally, supplementation with tablets containing C. forskohlii extract, homotaurine, carnosine, folic acid, vitamins of the $B$ group and magnesium in POAG patients compensated by IOP-lowering drugs during a period of 12 months showed a significant further decrease in IOP and an improvement in the pattern electroretinogram amplitude at 6,9 and 12 months, and foveal sensitivity at 12 months [266]. In another study, daily intake of a similar supplement for 4 months showed a decrease in IOP, improved light sensitivity and contrast sensitivity and a better quality of life in POAG patients [267]. Additionally, supplementation with French maritime pine bark/bilberry fruit extracts rich in anthocyanins to POAG patients for 4 weeks showed a reduced IOP [268].

Numerous eye drops of various classes, such as prostaglandin analogs, beta blockers, carbonic anhydrase inhibitors, adrenergic agonists, miotics and hyperosmotic agents, are often preferred over surgeries for the treatment of glaucoma [269]. One of the major issues in glaucoma treatment is patients' noncompliance, due to improper techniques of administering eye drops [270]. Another major issue is poor drug bioavailability across the blood-retinal barrier, limited retention capacity of the cul-de-sac (usually 7-10 $\mu \mathrm{L}$, maximum $50 \mu \mathrm{L}$ ), rapid drainage of the medication caused by gravity and washout by tearing or through the nasolacrimal duct [271]. The use of various nanoformulations such as nanoparticles, nanoemulsions and nano lipid vesicles to transport phytochemicals may be able to increase the bioavailability of the drugs to the eye. For instance, baicalein loaded in trimethyl chitosan nanoparticles showed a longer pre-ocular retention time and improved baicalein bioavailability, compared to baicalein solution [272]. Davis et al. [258] reported the use of a curcumin-loaded nanocarrier formulation using D- $\alpha$-tocopherol polyethene glycol 1000 succinate nanoparticles, with each particle measuring $<20 \mathrm{~nm}$ in diameter. In an OHT rat model, topical application of curcumin nanocarriers administered twice daily for three weeks was shown to significantly reduce RGC loss, but not in the free curcumin treatment group [258]. Additionally, the same study showed that curcumin nanocarriers protected retinal cells against $\mathrm{CoCl}_{2}$-induced hypoxia and glutamate-induced toxicity in vitro, by significantly increasing cell viability [258]. Similarly, a chitosan-gelatin-based hydrogel containing curcumin-loaded nanoparticles decreased the inflammation (reduced expression of TNF and IL- $1 \alpha$ and -6 , associated with downregulated mitochondrial ROS production) and apoptosis levels (reduced TUNEL-positive cells and cleaved caspase-3 protein level) of human TM cells exposed to $\mathrm{H}_{2} \mathrm{O}_{2}$-induced oxidative stress [259]. Apart from curcumin, co-encapsulated resveratrol and quercetin in chitosan nanoparticles, and sodium alginatepoly (vinyl alcohol) electrospun nanofibers of forskolin showed an efficient IOP reduction 
in adult normotensive rabbits $[257,260]$. These studies demonstrated that phytochemical nanoformulations hold promising results, promoting their use as an alternative to existing glaucoma eye drops in clinical practice.

Lastly, it is important to use a suitable methodology to address the objectives of a study. Numerous studies used the Bcl-2/Bax ratio to imply that the therapeutic substance influences the activation of the intrinsic apoptotic pathway in RGCs, as shown by the numerous studies which have been reviewed here. However, the concept that both Bcl-2 and Bax expressions are in a stoichiometric 1:1 balance in cells reflects the old 'rheostat' model of the Bcl-2 family's protein function, a hypothetical model that was debunked over two decades ago when it was shown that a 1:1 interaction of these proteins was a laboratory artifact $[273,274]$. Additionally, the predominant anti-apoptotic protein expressed in the retinal cells, including the GCL, is the long form of $\mathrm{Bcl}-\mathrm{X}\left(\mathrm{Bcl}-\mathrm{X}_{\mathrm{L}}\right)$, which was found to be 16 times more abundant than Bcl-2 [275]. Furthermore, it is even questionable whether Bcl-2 is expressed in adult RGCs and may, in fact, be limited to Müller cells in the retina [276]. Therefore, the reporting of the $\mathrm{Bcl}-2 / \mathrm{Bax}$ ratio may not be a suitable marker to imply apoptosis in RGCs, and instead, the changes in Bcl- $\mathrm{X}_{\mathrm{L}}$ expression may correlate better with RGC apoptosis.

\section{Conclusions}

One of the most common causes of vision loss is glaucoma. Recent data have gained insight into glaucoma pathogenesis, which involves a complex interaction of LC cupping, insufficient ocular blood supply, oxidative stress and neuroinflammation. The use of natural products with antioxidant, anti-inflammatory and anti-apoptotic properties may prove to be beneficial in the treatment of glaucoma. Furthermore, natural products are easily available and are cost effective. Natural products have been shown to protect against RGC loss in in vitro and in vivo preclinical studies, as well as in clinical trials. The present review highlighted various natural products such as GBE, L. barbarum, D. kaki, T. wilfordii, saffron, curcumin, anthocyanin, caffeine, coenzyme $\mathrm{Q} 10$ and vitamins $\mathrm{B}_{3}, \mathrm{D}$ and $\mathrm{E}$ that confer neuroprotective effects on RGCs. Additionally, IOP has been shown to be reduced by treatment with marijuana, baicalein, forskolin, ginsenoside, resveratrol and hesperidin. GB, ginseng, anthocyanins and L. barbarum were reported to increase ocular blood flow in glaucoma. Additionally, caffeine administration has been shown to reduce IOP through its adenosine receptor antagonist properties. Although these may serve as alternative targets for glaucoma treatment other than IOP-lowering drugs, more evidence is required to warrant the recommendation of these novel targets. Admittedly, a few of these natural products have had no or limited clinical testing, restricting their potential use in the treatment of glaucoma. Nevertheless, it is important to ensure that the bioavailability and safety of these natural products are checked in well-designed randomized clinical trials to further determine their therapeutic potential in glaucoma.

Author Contributions: Conceptualization, R.H.S. and S.D.; writing-original draft preparation, R.H.S. and S.R.S.; writing-review and editing, S.L.T. and S.D. All authors have read and agreed to the published version of the manuscript.

Funding: This research received no external funding.

Institutional Review Board Statement: Not applicable.

Informed Consent Statement: Not applicable.

Conflicts of Interest: The authors declare no conflict of interest.

\section{References}

1. Bourne, R.R.; Taylor, H.R.; Flaxman, S.R.; Keeffe, J.; Leasher, J.; Naidoo, K.; Pesudovs, K.; White, R.A.; Wong, T.Y.; Resnikoff, S.; et al. Number of people blind or visually impaired by glaucoma worldwide and in world regions 1990-2010: A meta-analysis. PLoS ONE 2016, 11, e0162229. [CrossRef]

2. World Health Organization. World Report on Vision; World Health Organization: Geneva, Switzerland, 2019 ; pp. 1-160. 
3. Tham, Y.C.; Li, X.; Wong, T.Y.; Quigley, H.A.; Aung, T.; Cheng, C.Y. Global prevalence of glaucoma and projections of glaucoma burden through 2040: A systematic review and meta-analysis. Ophthalmology 2014, 121, 2081-2090. [CrossRef]

4. Bajwa, M.N.; Malik, M.I.; Siddiqui, S.A.; Dengel, A.; Shafait, F.; Neumeier, W.; Ahmed, S. Two-stage framework for optic disc localization and glaucoma classification in retinal fundus images using deep learning. BMC Med. Inform. Decis. Mak. 2019, 19, 136. [CrossRef]

5. Tharmathurai, S.; Muhammad-Ikmal, M.K.; Razak, A.A.; Che-Hamzah, J.; Azhany, Y.; Fazilawati, Q.; Liza-Sharmini, A.T. Depression and severity of glaucoma among older adults in urban and suburban areas. J. Glaucoma 2021, 30, e205-e212. [CrossRef] [PubMed]

6. Chandramohan, H.; Wan Abdul Halim, W.H.; Azizi, H.A.; Hing, S.T.; Zainal Rain, S.L.; Abdul Rahman, G.Y.; Mohd Khialdin, S. Quality of life and severity of glaucoma: A study using Glaucol-36 Questionnaire at Universiti Kebangsaan Malaysia Medical Centre (UKMMC). Int. Med. J. 2017, 24, 61-64.

7. Ko, F.; Boland, M.V.; Gupta, P.; Gadkaree, S.K.; Vitale, S.; Guallar, E.; Zhao, D.; Friedman, D.S. Diabetes, triglyceride levels, and other risk factors for glaucoma in the National Health and Nutrition Examination Survey 2005-2008. Investig. Ophthalmol. Vis. Sci. 2016, 57, 2152-2157. [CrossRef] [PubMed]

8. Kreft, D.; Doblhammer, G.; Guthoff, R.F.; Frech, S. Prevalence, incidence, and risk factors of primary open-angle glaucoma-A cohort study based on longitudinal data from a German public health insurance. BMC Public Health 2019, 19, 851. [CrossRef]

9. Chen, M.; Yu, X.; Xu, J.; Ma, J.; Chen, X.; Chen, B.; Gu, Y.; Wang, K. Association of gene polymorphisms with primary open angle glaucoma: A systematic review and meta-analysis. Investig. Ophthalmol. Vis. Sci. 2019, 60, 1105-1121. [CrossRef]

10. Han, X.; Souzeau, E.; Ong, J.S.; An, J.; Siggs, O.M.; Burdon, K.P.; Best, S.; Goldberg, I.; Healey, P.R.; Graham, S.L.; et al. Myocilin gene Gln368Ter variant penetrance and association with glaucoma in population-based and registry-based studies. JAMA Ophthalmol. 2019, 137, 28-35. [CrossRef] [PubMed]

11. Choplin, N.T. Classification of glaucoma. In Atlas of Glaucoma; Choplin, N.T., Traverso, C.E., Eds.; CRC Press: Boca Raton, FL, USA, 2014; pp. 7-12.

12. Khaled Alsirhani, E.; Sahli Abdulaziz Ali, Y.; Mutlaq Ayidh Alosaimi, S.; Ahmed Ali Alkhawajah, S.; Khalifah Alsaqer, S.; Alanazi, M.S.H.; Alanzi, H.O.H.; Alghamdi, L.S.A.; Salman Alfaifi, A.; Almutairi, J.A. An overview of glaucoma diagnosis \& management: A literature review. Arch. Pharm. Pract. 2020, 11, 66-69.

13. Weinreb, R.N.; Leung, C.K.; Crowston, J.G.; Medeiros, F.A.; Friedman, D.S.; Wiggs, J.L.; Martin, K.R. Primary open-angle glaucoma. Nat. Rev. Dis. Primers 2016, 2, 16067. [CrossRef] [PubMed]

14. Wright, C.; Tawfik, M.A.; Waisbourd, M.; Katz, L.J. Primary angle-closure glaucoma: An update. Acta Ophthalmol. 2016, 94, 217-225. [CrossRef] [PubMed]

15. Standring, S. Gray's Anatomy: The Anatomical Basis of Clinical Practice, 42nd ed.; Standring, S., Ed.; Elsevier Limited: New York, NY, USA, 2020; pp. 1-1606.

16. Li, L.; Song, F. Biomechanical research into lamina cribrosa in glaucoma. Natl. Sci. Rev. 2020, 7, 1277-1279. [CrossRef]

17. Irnaten, M.; Zhdanov, A.; Brennan, D.; Crotty, T.; Clark, A.; Papkovsky, D.; O’Brien, C. Activation of the NFAT-calcium signaling pathway in human lamina cribrosa cells in glaucoma. Investig. Ophthalmol. Vis. Sci. 2018, 59, 831-842. [CrossRef] [PubMed]

18. Zhavoronkov, A.; Izumchenko, E.; Kanherkar, R.R.; Teka, M.; Cantor, C.; Manaye, K.; Sidransky, D.; West, M.D.; Makarev, E.; Csoka, A.B. Pro-fibrotic pathway activation in trabecular meshwork and lamina cribrosa is the main driving force of glaucoma. Cell Cycle 2016, 15, 1643-1652. [CrossRef]

19. Ivers, K.M.; Sredar, N.; Patel, N.B.; Rajagopalan, L.; Queener, H.M.; Twa, M.D.; Harwerth, R.S.; Porter, J. In Vivo changes in lamina cribrosa microarchitecture and optic nerve head structure in early experimental glaucoma. PLoS ONE 2015, 10, e0134223. [CrossRef]

20. Wu, J.; Du, Y.; Li, J.; Fan, X.; Lin, C.; Wang, N. The influence of different intraocular pressure on lamina cribrosa parameters in glaucoma and the relation clinical implication. Sci. Rep. 2021, 11, 9755. [CrossRef]

21. Kim, J.A.; Kim, T.W.; Weinreb, R.N.; Lee, E.J.; Girard, M.J.A.; Mari, J.M. Lamina cribrosa morphology predicts progressive retinal nerve fiber layer loss in eyes with suspected glaucoma. Sci. Rep. 2018, 8, 738. [CrossRef]

22. Maddineni, P.; Kasetti, R.B.; Patel, P.D.; Millar, J.C.; Kiehlbauch, C.; Clark, A.F.; Zode, G.S. CNS axonal degeneration and transport deficits at the optic nerve head precede structural and functional loss of retinal ganglion cells in a mouse model of glaucoma. Mol. Neurodegener. 2020, 15, 48. [CrossRef]

23. Berdahl, J.P.; Ferguson, T.J.; Samuelson, T.W. Periodic normalization of the translaminar pressure gradient prevents glaucomatous damage. Med. Hypotheses 2020, 144, 110258. [CrossRef]

24. Li, L.; Bian, A.; Cheng, G.; Zhou, Q. Posterior displacement of the lamina cribrosa in normal-tension and high-tension glaucoma. Acta Ophthalmol. 2016, 94, e492-e500. [CrossRef]

25. Pircher, A.; Remonda, L.; Weinreb, R.N.; Killer, H.E. Translaminar pressure in Caucasian normal tension glaucoma patients. Acta Ophthalmol. 2017, 95, e524-e531. [CrossRef]

26. Siaudvytyte, L.; Januleviciene, I.; Ragauskas, A.; Bartusis, L.; Meiliuniene, I.; Siesky, B.; Harris, A. The difference in translaminar pressure gradient and neuroretinal rim area in glaucoma and healthy subjects. J. Ophthalmol. 2014, 2014, 937360. [CrossRef]

27. Trivli, A.; Koliarakis, I.; Terzidou, C.; Goulielmos, G.N.; Siganos, C.S.; Spandidos, D.A.; Dalianis, G.; Detorakis, E.T. Normaltension glaucoma: Pathogenesis and genetics. Exp. Ther. Med. 2019, 17, 563-574. [CrossRef] 
28. Burgoyne, C.F. A biomechanical paradigm for axonal insult within the optic nerve head in aging and glaucoma. Exp. Eye Res. 2011, 93, 120-132. [CrossRef]

29. Shiga, Y.; Kunikata, H.; Aizawa, N.; Kiyota, N.; Maiya, Y.; Yokoyama, Y.; Omodaka, K.; Takahashi, H.; Yasui, T.; Kato, K.; et al. Optic nerve head blood flow, as measured by laser speckle flowgraphy, is significantly reduced in preperimetric glaucoma. Curr. Eye Res. 2016, 41, 1447-1453. [CrossRef]

30. Shiga, Y.; Aizawa, N.; Tsuda, S.; Yokoyama, Y.; Omodaka, K.; Kunikata, H.; Yasui, T.; Kato, K.; Kurashima, H.; Miyamoto, E.; et al. Preperimetric glaucoma prospective study (PPGPS): Predicting visual field progression with basal optic nerve head blood flow in normotensive PPG eyes. Transl. Vis. Sci. Technol. 2018, 7, 11. [CrossRef] [PubMed]

31. Rong, X.; Cai, Y.; Li, M.; Chen, X.; Kang, L.; Yang, L. Relationship between nailfold capillary morphology and retinal thickness and retinal vessel density in primary open-angle and angle-closure glaucoma. Acta Ophthalmol. 2020, 98, e882-e887. [CrossRef] [PubMed]

32. Abegao Pinto, L.; Willekens, K.; Van Keer, K.; Shibesh, A.; Molenberghs, G.; Vandewalle, E.; Stalmans, I. Ocular blood flow in glaucoma-The Leuven Eye Study. Acta Ophthalmol. 2016, 94, 592-598. [CrossRef] [PubMed]

33. Tobe, L.A.; Harris, A.; Hussain, R.M.; Eckert, G.; Huck, A.; Park, J.; Egan, P.; Kim, N.J.; Siesky, B. The role of retrobulbar and retinal circulation on optic nerve head and retinal nerve fibre layer structure in patients with open-angle glaucoma over an 18-month period. Br. J. Ophthalmol. 2015, 99, 609-612. [CrossRef]

34. Kiyota, N.; Shiga, Y.; Omodaka, K.; Pak, K.; Nakazawa, T. Time-course changes in optic nerve head blood flow and retinal nerve fiber layer thickness in eyes with open-angle glaucoma. Ophthalmology 2021, 128, 663-671. [CrossRef] [PubMed]

35. Ahmad, S.S. Controversies in the vascular theory of glaucomatous optic nerve degeneration. Taiwan J. Ophthalmol. 2016, 6, 182-186. [CrossRef]

36. Chidlow, G.; Wood, J.P.M.; Casson, R.J. Investigations into hypoxia and oxidative stress at the optic nerve head in a rat model of glaucoma. Front. Neurosci. 2017, 11, 478. [CrossRef] [PubMed]

37. Jassim, A.H.; Fan, Y.; Pappenhagen, N.; Nsiah, N.Y.; Inman, D.M. Oxidative stress and hypoxia modify mitochondrial homeostasis during glaucoma. Antioxid. Redox Signal. 2021, 35, 1341-1357. [CrossRef]

38. Hondur, G.; Goktas, E.; Yang, X.; Al-Aswad, L.; Auran, J.D.; Blumberg, D.M.; Cioffi, G.A.; Liebmann, J.M.; Suh, L.H.; Trief, D.; et al. Oxidative stress-related molecular biomarker candidates for glaucoma. Investig. Ophthalmol. Vis. Sci. 2017, 58, 4078-4088. [CrossRef]

39. Li, S.; Shao, M.; Li, Y.; Li, X.; Wan, Y.; Sun, X.; Cao, W. Relationship between oxidative stress biomarkers and visual field progression in patients with primary angle closure glaucoma. Oxidative Med. Cell. Longev. 2020, 2020, 2701539. [CrossRef] [PubMed]

40. Tang, B.; Li, S.; Cao, W.; Sun, X. The association of oxidative stress status with open-angle glaucoma and exfoliation glaucoma: A systematic review and meta-analysis. J. Ophthalmol. 2019, 2019, 1803619. [CrossRef]

41. Margeta, M.A.; Lad, E.M.; Proia, A.D. CD163+ macrophages infiltrate axon bundles of postmortem optic nerves with glaucoma. Graefes Arch. Clin. Exp. Ophthalmol. 2018, 256, 2449-2456. [CrossRef]

42. Tang, B.; Li, S.; Han, J.; Cao, W.; Sun, X. Associations between blood cell profiles and primary open-angle glaucoma: A retrospective case-control study. Ophthalmic Res. 2020, 63, 413-422. [CrossRef]

43. Huang, P.; Qi, Y.; Xu, Y.S.; Liu, J.; Liao, D.; Zhang, S.S.; Zhang, C. Serum cytokine alteration is associated with optic neuropathy in human primary open angle glaucoma. J. Glaucoma 2010, 19, 324-330. [CrossRef] [PubMed]

44. Kondkar, A.A.; Azad, T.A.; Almobarak, F.A.; Kalantan, H.; Al-Obeidan, S.A.; Abu-Amero, K.K. Elevated levels of plasma tumor necrosis factor alpha in patients with pseudoexfoliation glaucoma. Clin. Ophthalmol. 2018, 12, 153-159. [CrossRef]

45. Kondkar, A.A.; Sultan, T.; Almobarak, F.A.; Kalantan, H.; Al-Obeidan, S.A.; Abu-Amero, K.K. Association of increased levels of plasma tumor necrosis factor alpha with primary open-angle glaucoma. Clin. Ophthalmol. 2018, 12, 701-706. [CrossRef]

46. Duvesh, R.; Puthuran, G.; Srinivasan, K.; Rengaraj, V.; Krishnadas, S.R.; Rajendrababu, S.; Balakrishnan, V.; Ramulu, P.; Sundaresan, P. Multiplex cytokine analysis of aqueous humor from the patients with chronic primary angle closure glaucoma. Curr. Eye Res. 2017, 42, 1608-1613. [CrossRef]

47. Wang, L.; Cioffi, G.A.; Cull, G.; Dong, J.; Fortune, B. Immunohistologic evidence for retinal glial cell changes in human glaucoma. Investig. Ophthalmol. Vis. Sci. 2002, 43, 1088-1094.

48. Wang, X.; Tay, S.S.; $\mathrm{Ng}$, Y.K. An immunohistochemical study of neuronal and glial cell reactions in retinae of rats with experimental glaucoma. Exp. Brain Res. 2000, 132, 476-484. [CrossRef] [PubMed]

49. Harun-Or-Rashid, M.; Inman, D.M. Reduced AMPK activation and increased HCAR activation drive anti-inflammatory response and neuroprotection in glaucoma. J. Neuroinflamm. 2018, 15, 313. [CrossRef]

50. Hernandez, H.; Roberts, A.L.; McDowell, C.M. Nuclear factor-kappa beta signaling is required for transforming growth factor Beta-2 induced ocular hypertension. Exp. Eye Res. 2020, 191, 107920. [CrossRef]

51. Yang, X.; Zeng, Q.; Baris, M.; Tezel, G. Transgenic inhibition of astroglial NF- $\mathrm{kB}$ restrains the neuroinflammatory and neurodegenerative outcomes of experimental mouse glaucoma. J. Neuroinflamm. 2020, 17, 252. [CrossRef] [PubMed]

52. Mac Nair, C.E.; Schlamp, C.L.; Montgomery, A.D.; Shestopalov, V.I.; Nickells, R.W. Retinal glial responses to optic nerve crush are attenuated in Bax-deficient mice and modulated by purinergic signaling pathways. J. Neuroinflamm. 2016, 13, 93. [CrossRef] [PubMed] 
53. Howell, G.R.; Soto, I.; Zhu, X.; Ryan, M.; Macalinao, D.G.; Sousa, G.L.; Caddle, L.B.; MacNicoll, K.H.; Barbay, J.M.; Porciatti, V.; et al. Radiation treatment inhibits monocyte entry into the optic nerve head and prevents neuronal damage in a mouse model of glaucoma. J. Clin. Investig. 2012, 122, 1246-1261. [CrossRef]

54. Reichenbach, A.; Bringmann, A. Glia of the human retina. Glia 2020, 68, 768-796. [CrossRef]

55. Magi, S.; Piccirillo, S.; Amoroso, S.; Lariccia, V. Excitatory amino acid transporters (EAATs): Glutamate transport and beyond. Int. J. Mol. Sci. 2019, 20, 5674. [CrossRef] [PubMed]

56. Naskar, R.; Vorwerk, C.K.; Dreyer, E.B. Concurrent downregulation of a glutamate transporter and receptor in glaucoma. Investig. Ophthalmol. Vis. Sci. 2000, 41, 1940-1944.

57. Harada, T.; Harada, C.; Nakamura, K.; Quah, H.M.; Okumura, A.; Namekata, K.; Saeki, T.; Aihara, M.; Yoshida, H.; Mitani, A.; et al. The potential role of glutamate transporters in the pathogenesis of normal tension glaucoma. J. Clin. Investig. 2007, 117, 1763-1770. [CrossRef]

58. Osborne, N.N.; Nunez-Alvarez, C.; Joglar, B.; Del Olmo-Aguado, S. Glaucoma: Focus on mitochondria in relation to pathogenesis and neuroprotection. Eur. J. Pharmacol. 2016, 787, 127-133. [CrossRef]

59. Muench, N.A.; Patel, S.; Maes, M.E.; Donahue, R.J.; Ikeda, A.; Nickells, R.W. The influence of mitochondrial dynamics and function on retinal ganglion cell susceptibility in optic nerve disease. Cells 2021, 10, 1593. [CrossRef]

60. Evangelho, K.; Mogilevskaya, M.; Losada-Barragan, M.; Vargas-Sanchez, J.K. Pathophysiology of primary open-angle glaucoma from a neuroinflammatory and neurotoxicity perspective: A review of the literature. Int. Ophthalmol. 2019, 39, 259-271. [CrossRef] [PubMed]

61. Almasieh, M.; Levin, L.A. Neuroprotection in glaucoma: Animal models and clinical trials. Annu. Rev. Vis. Sci. 2017, 3, 91-120. [CrossRef] [PubMed]

62. Kimura, A.; Noro, T.; Harada, T. Role of animal models in glaucoma research. Neural Regen. Res. 2020, 15, 1257-1258. [CrossRef]

63. Evangelho, K.; Mastronardi, C.A.; de-la-Torre, A. Experimental models of glaucoma: A powerful translational tool for the future development of new therapies for glaucoma in humans-a review of the literature. Medicina 2019, 55, 280. [CrossRef] [PubMed]

64. Harada, C.; Kimura, A.; Guo, X.; Namekata, K.; Harada, T. Recent advances in genetically modified animal models of glaucoma and their roles in drug repositioning. Acta Br. J. Ophthalmol. 2019, 103, 161-166. [CrossRef] [PubMed]

65. Yang, X.L.; van der Merwe, Y.; Sims, J.; Parra, C.; Ho, L.C.; Schuman, J.S.; Wollstein, G.; Lathrop, K.L.; Chan, K.C. Age-related Changes in eye, brain and visuomotor behavior in the DBA/2J mouse model of chronic glaucoma. Sci. Rep. 2018, 8, 4643. [CrossRef]

66. Porciatti, V.; Chou, T.H.; Feuer, W.J. C57BL/6J, DBA/2J, and DBA/2J. Gpnmb+ mice have different visual signal processing in the inner retina. Mol. Vis. 2010, 16, 2939-2947.

67. Fujikawa, K.; Iwata, T.; Inoue, K.; Akahori, M.; Kadotani, H.; Fukaya, M.; Watanabe, M.; Chang, Q.; Barnett, E.M.; Swat, W. VAV2 and VAV3 as candidate disease genes for spontaneous glaucoma in mice and humans. PLoS ONE 2010, 5, e9050. [CrossRef]

68. Reinehr, S.; Koch, D.; Weiss, M.; Froemel, F.; Voss, C.; Dick, H.B.; Fuchshofer, R.; Joachim, S.C. Loss of retinal ganglion cells in a new genetic mouse model for primary open-angle glaucoma. J. Cell. Mol. Med. 2019, 23, 5497-5507. [CrossRef]

69. Tseng, H.C.; Riday, T.T.; McKee, C.; Braine, C.E.; Bomze, H.; Barak, I.; Marean-Reardon, C.; John, S.W.; Philpot, B.D.; Ehlers, M.D. Visual impairment in an optineurin mouse model of primary open-angle glaucoma. Neurobiol. Aging 2015, 36, $2201-2212$. [CrossRef]

70. Sappington, R.M.; Carlson, B.J.; Crish, S.D.; Calkins, D.J. The microbead occlusion model: A paradigm for induced ocular hypertension in rats and mice. Investig. Ophthalmol. Vis. Sci. 2010, 51, 207-216. [CrossRef]

71. Vaghela, J.J.; Barvaliya, M.J.; Parmar, S.J.; Tripathi, C.R. Evaluation of efficacy of Aloe vera (L.) Burm. f. gel solution in methylcellulose-induced ocular hypertension in New Zealand white rabbits. J. Basic Clin. Physiol. Pharmacol. 2020, 32, 20190158. [CrossRef] [PubMed]

72. Moreno, M.C.; Marcos, H.J.; Oscar Croxatto, J.; Sande, P.H.; Campanelli, J.; Jaliffa, C.O.; Benozzi, J.; Rosenstein, R.E. A new experimental model of glaucoma in rats through intracameral injections of hyaluronic acid. Exp. Eye Res. 2005, 81, 71-80. [CrossRef] [PubMed]

73. Morrison, J.C.; Johnson, E.C.; Cepurna, W.O. Hypertonic saline injection model of experimental glaucoma in rats. In Glaucoma. Methods in Molecular Biology; Jakobs, T., Ed.; Humana Press: New York, NY, USA, 2018; Volume 1695, pp. 11-21.

74. Bai, Y.; Zhu, Y.; Chen, Q.; Xu, J.; Sarunic, M.V.; Saragovi, U.H.; Zhuo, Y. Validation of glaucoma-like features in the rat episcleral vein cauterization model. Chin. Med. J. 2014, 127, 359-364. [CrossRef]

75. Feng, L.; Chen, H.; Suyeoka, G.; Liu, X. A laser-induced mouse model of chronic ocular hypertension to characterize visual defects. J. Vis. Exp. 2013, 10, 50440. [CrossRef]

76. Yun, H.; Lathrop, K.L.; Yang, E.; Sun, M.; Kagemann, L.; Fu, V.; Stolz, D.B.; Schuman, J.S.; Du, Y. A laser-induced mouse model with long-term intraocular pressure elevation. PLoS ONE 2014, 9, e107446. [CrossRef]

77. Biermann, J.; van Oterendorp, C.; Stoykow, C.; Volz, C.; Jehle, T.; Boehringer, D.; Lagreze, W.A. Evaluation of intraocular pressure elevation in a modified laser-induced glaucoma rat model. Exp. Eye Res. 2012, 104, 7-14. [CrossRef] [PubMed]

78. Biswas, S.; Wan, K.H. Review of rodent hypertensive glaucoma models. Acta Ophthalmol. 2019, 97, e331-e340. [CrossRef] [PubMed] 
79. Honda, S.; Namekata, K.; Kimura, A.; Guo, X.; Harada, C.; Murakami, A.; Matsuda, A.; Harada, T. Survival of alpha and intrinsically photosensitive retinal ganglion cells in NMDA-induced neurotoxicity and a mouse model of normal tension glaucoma. Investig. Ophthalmol. Vis. Sci. 2019, 60, 3696-3707. [CrossRef]

80. Tang, Z.; Zhang, S.; Lee, C.; Kumar, A.; Arjunan, P.; Li, Y.; Zhang, F.; Li, X. An optic nerve crush injury murine model to study retinal ganglion cell survival. J. Vis. Exp. 2011, 10, e2685. [CrossRef]

81. Rovere, G.; Nadal-Nicolas, F.M.; Agudo-Barriuso, M.; Sobrado-Calvo, P.; Nieto-Lopez, L.; Nucci, C.; Villegas-Perez, M.P.; Vidal-Sanz, M. Comparison of retinal nerve fiber layer thinning and retinal ganglion cell loss after optic nerve transection in adult albino rats. Investig. Ophthalmol. Vis. Sci. 2015, 56, 4487-4498. [CrossRef] [PubMed]

82. Ing, E.; Ivers, K.M.; Yang, H.; Gardiner, S.K.; Reynaud, J.; Cull, G.; Wang, L.; Burgoyne, C.F. Cupping in the monkey optic nerve transection model consists of prelaminar tissue thinning in the absence of posterior laminar deformation. Investig. Ophthalmol. Vis. Sci. 2016, 57, 2914-2927. [CrossRef]

83. Yan, F.; Guo, S.; Chai, Y.; Zhang, L.; Liu, K.; Lu, Q.; Wang, N.; Li, S. Partial optic nerve transection in rats: A model established with a new operative approach to assess secondary degeneration of retinal ganglion cells. J. Vis. Exp. 2017, 10, e56272. [CrossRef]

84. Minhas, G.; Sharma, J.; Khan, N. Cellular stress response and immune signaling in retinal ischemia-reperfusion injury. Front. Immunol. 2016, 7, 444. [CrossRef]

85. Hartsock, M.J.; Cho, H.; Wu, L.; Chen, W.J.; Gong, J.; Duh, E.J. A Mouse Model of Retinal Ischemia-Reperfusion Injury through Elevation of Intraocular Pressure. J. Vis. Exp. 2016, 10, e54065. [CrossRef]

86. Van Bergen, N.J.; Wood, J.P.; Chidlow, G.; Trounce, I.A.; Casson, R.J.; Ju, W.K.; Weinreb, R.N.; Crowston, J.G. Recharacterization of the RGC-5 retinal ganglion cell line. Investig. Ophthalmol. Vis. Sci. 2009, 50, 4267-4272. [CrossRef]

87. Krishnamoorthy, R.R.; Clark, A.F.; Daudt, D.; Vishwanatha, J.K.; Yorio, T. A forensic path to RGC-5 cell line identification: Lessons learned. Investig. Ophthalmol. Vis. Sci. 2013, 54, 5712-5719. [CrossRef]

88. Chintalapudi, S.R.; Djenderedjian, L.; Stiemke, A.B.; Steinle, J.J.; Jablonski, M.M.; Morales-Tirado, V.M. Isolation and molecular profiling of primary mouse retinal ganglion cells: Comparison of phenotypes from healthy and glaucomatous retinas. Front. Aging Neurosci. 2016, 8, 93. [CrossRef]

89. Lusthaus, J.; Goldberg, I. Current management of glaucoma. Med. J. Aust. 2019, 210, 180-187. [CrossRef] [PubMed]

90. European Glaucoma Society Terminology and Guidelines for Glaucoma, 4th Edition—Chapter 3: Treatment principles and options Supported by the EGS Foundation: Part 1: Foreword; Introduction; Glossary; Chapter 3 Treatment principles and options. Acta Br. J. Ophthalmol. 2017, 101, 130-195. [CrossRef] [PubMed]

91. Wan, M.J.; Daniel, S.; Kassam, F.; Mutti, G.; Butty, Z.; Kasner, O.; Trope, G.E.; Buys, Y.M. Survey of complementary and alternative medicine use in glaucoma patients. J. Glaucoma 2012, 21, 79-82. [CrossRef]

92. AlSalman, S.; AlHussaini, M.A.; Khandekar, R.B.; Edward, D.P. The proportion of complementary and alternative medicine utilization among Saudi population for eye care: Cross-sectional study. Cureus 2021, 13, e13109. [CrossRef] [PubMed]

93. Jaber, D.; Ghannam, R.A.; Rashed, W.; Shehadeh, M.; Zyoud, S.H. Use of complementary and alternative therapies by patients with eye diseases: A hospital-based cross-sectional study from Palestine. BMC Complementary Med. Ther. 2021, 21, 3. [CrossRef]

94. Achete de Souza, G.; de Marqui, S.V.; Matias, J.N.; Guiguer, E.L.; Barbalho, S.M. Effects of Ginkgo biloba on diseases related to oxidative stress. Planta Med. 2020, 86, 376-386. [CrossRef]

95. Liu, X.G.; Wu, S.Q.; Li, P.; Yang, H. Advancement in the chemical analysis and quality control of flavonoid in Ginkgo biloba. J. Pharm. Biomed. Anal. 2015, 113, 212-225. [CrossRef]

96. Cho, H.K.; Kim, S.; Lee, E.J.; Kee, C. Neuroprotective effect of Ginkgo biloba extract against hypoxic retinal ganglion cell degeneration in vitro and in vivo. J. Med. Food 2019, 22, 771-778. [CrossRef] [PubMed]

97. Fang, L.; Neutzner, A.; Turtschi, S.; Flammer, J.; Mozaffarieh, M. The effect of Ginkgo biloba and Nifedipine on DNA breaks in circulating leukocytes of glaucoma patients. Expert Rev. Ophthalmol. 2015, 10, 313-318. [CrossRef]

98. Lee, J.; Sohn, S.W.; Kee, C. Effect of Ginkgo biloba extract on visual field progression in normal tension glaucoma. J. Glaucoma 2013, 22, 780-784. [CrossRef] [PubMed]

99. Shim, S.H.; Kim, J.M.; Choi, C.Y.; Kim, C.Y.; Park, K.H. Ginkgo biloba extract and bilberry anthocyanins improve visual function in patients with normal tension glaucoma. J. Med. Food 2012, 15, 818-823. [CrossRef]

100. Park, J.W.; Kwon, H.J.; Chung, W.S.; Kim, C.Y.; Seong, G.J. Short-term effects of Ginkgo biloba extract on peripapillary retinal blood flow in normal tension glaucoma. Korean J. Ophthalmol. 2011, 25, 323-328. [CrossRef] [PubMed]

101. Sabaner, M.C.; Dogan, M.; Altin, S.S.; Balaman, C.; Yilmaz, C.; Omur, A.; Zeybek, I.; Palaz, M. Ginkgo Biloba affects microvascular morphology: A prospective optical coherence tomography angiography pilot study. Int. Ophthalmol. 2021, 41, $1053-1061$. [CrossRef]

102. Ma, K.; Xu, L.; Zhang, H.; Zhang, S.; Pu, M.; Jonas, J.B. The effect of ginkgo biloba on the rat retinal ganglion cell survival in the optic nerve crush model. Acta Ophthalmol. 2010, 88, 553-557. [CrossRef]

103. Fan, X.X.; Cao, Z.Y.; Liu, M.X.; Liu, W.J.; Xu, Z.L.; Tu, P.F.; Wang, Z.Z.; Cao, L.; Xiao, W. Diterpene Ginkgolides Meglumine Injection inhibits apoptosis induced by optic nerve crush injury via modulating MAPKs signaling pathways in retinal ganglion cells. J. Ethnopharmacol. 2021, 279, 114371. [CrossRef]

104. Li, Y.; Cheng, Z.; Wang, K.; Zhu, X.; Ali, Y.; Shu, W.; Bao, X.; Zhu, L.; Fan, X.; Murray, M.; et al. Procyanidin B2 and rutin in Ginkgo biloba extracts protect human retinal pigment epithelial (RPE) cells from oxidative stress by modulating Nrf2 and Erk1/2 signalling. Exp. Eye Res. 2021, 207, 108586. [CrossRef] 
105. Yu, H.; Dong, H.; Zhang, Y.; Liu, Q. A network pharmacology-based strategy for predicting the protective mechanism of Ginkgo biloba on damaged retinal ganglion cells. Chin. J. Nat. Med. 2021, 19, 1-13. [CrossRef]

106. Xiao, J.R.; Do, C.W.; To, C.H. Potential therapeutic effects of baicalein, baicalin, and wogonin in ocular disorders. J. Ocul. Pharmacol. Ther. 2014, 30, 605-614. [CrossRef]

107. Pan, L.; Cho, K.S.; Yi, I.; To, C.H.; Chen, D.F.; Do, C.W. Baicalein, baicalin, and wogonin: Protective effects against ischemiainduced neurodegeneration in the brain and retina. Oxidative Med. Cell. Longev. 2021, 2021, 8377362. [CrossRef]

108. Song, J.; Kim, Y.S.; Lee, D.; Kim, H. Safety evaluation of root extract of Pueraria lobata and Scutellaria baicalensis in rats. BMC Complementary Med. Ther. Vol. 2020, 20, 226. [CrossRef] [PubMed]

109. Yang, J.; Zhang, M.; Song, Q.; Li, S.; Zhao, X.; Kan, L.; Zhu, S. Integrating network pharmacological and experimental models to investigate the therapeutic effects of baicalein in glaucoma. Chin. Med. 2021, 16, 124. [CrossRef]

110. Chao, H.M.; Chuang, M.J.; Liu, J.H.; Liu, X.Q.; Ho, L.K.; Pan, W.H.; Zhang, X.M.; Liu, C.M.; Tsai, S.K.; Kong, C.W.; et al. Baicalein protects against retinal ischemia by antioxidation, antiapoptosis, downregulation of HIF-1alpha, VEGF, and MMP-9 and upregulation of HO-1. J. Ocul. Pharmacol. Ther. 2013, 29, 539-549. [CrossRef]

111. Xu, Y.; Yang, B.; Hu, Y.; Lu, L.; Lu, X.; Wang, J.; Xu, F.; Yu, S.; Huang, J.; Liang, X. Wogonin prevents TLR4-NF-kB-medicated neuro-inflammation and improves retinal ganglion cells survival in retina after optic nerve crush. Oncotarget 2016, 7, 72503-72517. [CrossRef] [PubMed]

112. Zhao, N.; Shi, J.; Xu, H.; Luo, Q.; Li, Q.; Liu, M. Baicalin suppresses glaucoma pathogenesis by regulating the PI3K/AKT signaling in vitro and in vivo. Bioengineered 2021, 12, 10187-10198. [CrossRef]

113. Gong, L.; Zhu, J. Baicalin alleviates oxidative stress damage in trabecular meshwork cells in vitro. Naunyn-Schmiedeberg's Arch. Pharmacol. 2018, 391, 51-58. [CrossRef]

114. Srivastava, S.; Misra, A.; Mishra, P.; Shukla, P.; Kumar, M.; Sundaresan, V.; Negi, K.S.; Agrawal, P.K.; Rawat, A.K.S. Molecular and chemotypic variability of forskolin in Coleus forskohlii Briq., a high value industrial crop collected from Western Himalayas (India). RSC Adv. 2017, 7, 8843-8851. [CrossRef]

115. Shim, M.S.; Kim, K.Y.; Ju, W.K. Role of cyclic AMP in the eye with glaucoma. BMB Rep. 2017, 50, 60-70. [CrossRef] [PubMed]

116. Shahidullah, M.; Wilson, W.S.; Rafiq, K.; Sikder, M.H.; Ferdous, J.; Delamere, N.A. Terbutaline, forskolin and cAMP reduce secretion of aqueous humour in the isolated bovine eye. PLoS ONE 2020, 15, e0244253. [CrossRef]

117. Majeed, M.; Nagabhushanam, K.; Natarajan, S.; Vaidyanathan, P.; Kumar, S.K. A double-blind, randomized clinical trial to evaluate the efficacy and safety of forskolin eye drops $1 \%$ in the treatment of open angle glaucoma-A comparative study. J. Clin. Trials 2014, 4, 1000184. [CrossRef]

118. Majeed, M.; Nagabhushanam, K.; Natarajan, S.; Vaidyanathan, P.; Karri, S.K.; Jose, J.A. Efficacy and safety of $1 \%$ forskolin eye drops in open angle glaucoma-An open label study. Saudi J. Ophthalmol. 2015, 29, 197-200. [CrossRef]

119. Locri, F.; Cammalleri, M.; Dal Monte, M.; Rusciano, D.; Bagnoli, P. Protective efficacy of a dietary supplement based on forskolin, homotaurine, spearmint extract, and group B vitamins in a mouse model of optic nerve injury. Nutrients 2019, 11, 2931. [CrossRef] [PubMed]

120. Cammalleri, M.; Dal Monte, M.; Amato, R.; Bagnoli, P.; Rusciano, D. A dietary combination of forskolin with homotaurine, spearmint and B vitamins protects injured retinal ganglion cells in a rodent model of hypertensive glaucoma. Nutrients $\mathbf{2 0 2 0}$ 12, 1189. [CrossRef]

121. Fan, H.; Lin, P.; Kang, Q.; Zhao, Z.L.; Wang, J.; Cheng, J.Y. Metabolism and pharmacological mechanisms of active ingredients in Erigeron breviscapus. Curr. Drug Metab. 2021, 22, 24-39. [CrossRef]

122. Zhong, Y.; Xiang, M.; Ye, W.; Cheng, Y.; Jiang, Y. Visual field protective effect of Erigeron breviscapus (vant.) Hand. Mazz. extract on glaucoma with controlled intraocular pressure: A randomized, double-blind, clinical trial. Drugs R D 2010, 10, 75-82. [CrossRef]

123. Lu, X.J.; Zhang, F.W.; Cheng, L.; Liu, A.Q.; Duan, J.G. Effect on multifocal electroretinogram in persistently elevated intraocular pressure by erigeron breviscapus extract. J. Ophthalmol. 2011, 4, 349-352. [CrossRef]

124. Zhong, Y.; Xiang, M.; Ye, W.; Huang, P.; Cheng, Y.; Jiang, Y. Neuroprotective effect of Erigeron Breviscapus (vant) Hand-mazz extract on retinal ganglion cells in rabbits with chronic elevated intraocular pressure. Asian Biomed. 2011, 5, 195-203. [CrossRef]

125. Yin, S.; Wang, Z.F.; Duan, J.G.; Ji, L.; Lu, X.J. Extraction (DSX) from Erigeron breviscapus modulates outward potassium currents in rat retinal ganglion cells. Int. J. Ophthalmol. 2015, 8, 1101-1106. [CrossRef]

126. Zhu, J.; Sainulabdeen, A.; Akers, K.; Adi, V.; Sims, J.R.; Yarsky, E.; Yan, Y.; Yu, Y.; Ishikawa, H.; Leung, C.K.; et al. Oral scutellarin treatment ameliorates retinal thinning and visual deficits in experimental glaucoma. Front. Med. 2021, 8, 681169. [CrossRef] [PubMed]

127. Zhu, J.; Chen, L.; Qi, Y.; Feng, J.; Zhu, L.; Bai, Y.; Wu, H. Protective effects of Erigeron breviscapus Hand.- Mazz. (EBHM) extract in retinal neurodegeneration models. Mol. Vis. 2018, 24, 315-325.

128. Gao, Y.; Wei, Y.; Wang, Y.; Gao, F.; Chen, Z. Lycium barbarum: A traditional chinese herb and a promising anti-aging agent. Aging Dis. 2017, 8, 778-791. [CrossRef]

129. Masci, A.; Carradori, S.; Casadei, M.A.; Paolicelli, P.; Petralito, S.; Ragno, R.; Cesa, S. Lycium barbarum polysaccharides: Extraction, purification, structural characterisation and evidence about hypoglycaemic and hypolipidaemic effects. A review. Food Chem. 2018, 254, 377-389. [CrossRef] 
130. Mocan, A.; Vlase, L.; Vodnar, D.C.; Bischin, C.; Hanganu, D.; Gheldiu, A.M.; Oprean, R.; Silaghi-Dumitrescu, R.; Crisan, G. Polyphenolic content, antioxidant and antimicrobial activities of Lycium barbarum L. and Lycium chinense Mill. leaves. Molecules 2014, 19, 10056-10073. [CrossRef] [PubMed]

131. Mi, X.S.; Feng, Q.; Lo, A.C.; Chang, R.C.; Lin, B.; Chung, S.K.; So, K.F. Protection of retinal ganglion cells and retinal vasculature by Lycium barbarum polysaccharides in a mouse model of acute ocular hypertension. PLoS ONE 2012, 7, e45469. [CrossRef]

132. Lakshmanan, Y.; Wong, F.S.; Yu, W.Y.; Li, S.Z.; Choi, K.Y.; So, K.F.; Chan, H.H. Lycium barbarum polysaccharides rescue neurodegeneration in an acute ocular hypertension rat model under pre- and posttreatment conditions. Investig. Ophthalmol. Vis. Sci. 2019, 60, 2023-2033. [CrossRef] [PubMed]

133. Mi, X.S.; Chiu, K.; Van, G.; Leung, J.W.; Lo, A.C.; Chung, S.K.; Chang, R.C.; So, K.F. Effect of Lycium barbarum polysaccharides on the expression of endothelin-1 and its receptors in an ocular hypertension model of rat glaucoma. Neural Regen. Res. 2012, 7, 645-651. [CrossRef]

134. Lakshmanan, Y.; Wong, F.S.Y.; Zuo, B.; So, K.F.; Bui, B.V.; Chan, H.H. Posttreatment intervention with Lycium barbarum polysaccharides is neuroprotective in a rat model of chronic ocular hypertension. Investig. Ophthalmol. Vis. Sci. 2019, 60, 4606-4618. [CrossRef]

135. Chu, P.H.; Li, H.Y.; Chin, M.P.; So, K.F.; Chan, H.H. Effect of Lycium barbarum (wolfberry) polysaccharides on preserving retinal function after partial optic nerve transection. PLoS ONE 2013, 8, e81339. [CrossRef] [PubMed]

136. Li, H.; Liang, Y.; Chiu, K.; Yuan, Q.; Lin, B.; Chang, R.C.; So, K.F. Lycium barbarum (wolfberry) reduces secondary degeneration and oxidative stress, and inhibits JNK pathway in retina after partial optic nerve transection. PLoS ONE 2013, 8, e68881. [CrossRef]

137. Liu, L.; Sha, X.Y.; Wu, Y.N.; Chen, M.T.; Zhong, J.X. Lycium barbarum polysaccharides protects retinal ganglion cells against oxidative stress injury. Neural Regen. Res. 2020, 15, 1526-1531. [CrossRef]

138. Liu, Y.; Zhang, Y. Lycium barbarum polysaccharides alleviate hydrogen peroxide-induced injury by up-regulation of miR-4295 in human trabecular meshwork cells. Exp. Mol. Pathol. 2019, 106, 109-115. [CrossRef] [PubMed]

139. Li, H.Y.; Huang, M.; Luo, Q.Y.; Hong, X.; Ramakrishna, S.; So, K.F. Lycium barbarum (Wolfberry) increases retinal ganglion cell survival and affects both microglia/macrophage polarization and autophagy after rat partial optic nerve transection. Cell Transpl. 2019, 28, 607-618. [CrossRef] [PubMed]

140. Mi, X.S.; Feng, Q.; Lo, A.C.Y.; Chang, R.C.; Chung, S.K.; So, K.F. Lycium barbarum polysaccharides related RAGE and Abeta levels in the retina of mice with acute ocular hypertension and promote maintenance of blood retinal barrier. Neural Regen. Res. 2020, 15, 2344-2352. [CrossRef]

141. Xu, S.; Liu, S.; Yan, G. Lycium barbarum exerts protection against glaucoma-like injury via inhibition of MMP-9 signaling in vitro. Med. Sci. Monit. 2019, 25, 9794-9800. [CrossRef] [PubMed]

142. Comes, N.; Buie, L.K.; Borras, T. Evidence for a role of angiopoietin-like 7 (ANGPTL7) in extracellular matrix formation of the human trabecular meshwork: Implications for glaucoma. Genes Cells 2011, 16, 243-259. [CrossRef]

143. Weinreb, R.N.; Robinson, M.R.; Dibas, M.; Stamer, W.D. Matrix metalloproteinases and glaucoma treatment. J. Ocul. Pharmacol. Ther. 2020, 36, 208-228. [CrossRef]

144. Yang, D.; So, K.F.; Lo, A.C. Lycium barbarum polysaccharide extracts preserve retinal function and attenuate inner retinal neuronal damage in a mouse model of transient retinal ischaemia. Clin. Exp. Ophthalmol. 2017, 45, 717-729. [CrossRef]

145. He, M.; Pan, H.; Chang, R.C.; So, K.F.; Brecha, N.C.; Pu, M. Activation of the Nrf2/HO-1 antioxidant pathway contributes to the protective effects of Lycium barbarum polysaccharides in the rodent retina after ischemia-reperfusion-induced damage. $P L O S$ ONE 2014, 9, e84800. [CrossRef] [PubMed]

146. Wu, I.H.; Chan, S.M.; Lin, C.T. The neuroprotective effect of submicron and blended Lycium barbarum for experiment retinal ischemia and reperfusion injury in rats. J. Vet. Med. Sci. 2020, 82, 1719-1728. [CrossRef]

147. Matheus, J.R.V.; Andrade, C.J.d.; Miyahira, R.F.; Fai, A.E.C. Persimmon (Diospyros Kaki L.): Chemical Properties, Bioactive Compounds and Potential Use in the Development of New Products-A Review. Food Rev. Int. 2020, 10, 1-18. [CrossRef]

148. Hossain, A.; Moon, H.K.; Kim, J.K. Antioxidant properties of Korean major persimmon (Diospyros kaki) leaves. Food Sci. Biotechnol. 2018, 27, 177-184. [CrossRef]

149. Ryul Ahn, H.; Kim, K.A.; Kang, S.W.; Lee, J.Y.; Kim, T.J.; Jung, S.H. Persimmon leaves (Diospyros kaki) extract protects optic nerve crush-induced retinal degeneration. Sci. Rep. 2017, 7, 46449. [CrossRef]

150. Ahn, H.R.; Yang, J.W.; Kim, J.Y.; Lee, C.Y.; Kim, T.J.; Jung, S.H. The intraocular pressure-lowering effect of persimmon leaves (Diospyros kaki) in a mouse model of glaucoma. Int. J. Mol. Sci. 2019, 20, 5268. [CrossRef] [PubMed]

151. Li, J.; Hao, J. Treatment of neurodegenerative diseases with bioactive components of Tripterygium wilfordii. Am. J. Chin. Med. 2019, 47, 769-785. [CrossRef]

152. Chen, S.R.; Dai, Y.; Zhao, J.; Lin, L.; Wang, Y.; Wang, Y. A mechanistic overview of triptolide and celastrol, natural products from Tripterygium wilfordii Hook F. Front. Pharmacol. 2018, 9, 104. [CrossRef] [PubMed]

153. Yang, F.; Wu, L.; Guo, X.; Wang, D.; Li, Y. Improved retinal ganglion cell survival through retinal microglia suppression by a chinese herb extract, triptolide, in the DBA/2J mouse model of glaucoma. Ocul. Immunol. Inflamm. 2013, 21, 378-389. [CrossRef]

154. Yang, F.; Wang, D.; Wu, L.; Li, Y. Protective effects of triptolide on retinal ganglion cells in a rat model of chronic glaucoma. Drug Des. Dev. Ther. 2015, 9, 6095-6107. [CrossRef] [PubMed]

155. Li, Y.F.; Zou, Y.F.; Chen, X.F.; Zhang, W. Effect of triptolide on retinal ganglion cell survival in an optic nerve crush model. Cell Mol. Biol. 2017, 63, 102-107. [CrossRef] 
156. Kyung, H.; Kwong, J.M.; Bekerman, V.; Gu, L.; Yadegari, D.; Caprioli, J.; Piri, N. Celastrol supports survival of retinal ganglion cells injured by optic nerve crush. Brain Res. 2015, 1609, 21-30. [CrossRef] [PubMed]

157. Gu, L.; Kwong, J.M.K.; Yadegari, D.; Yu, F.; Caprioli, J.; Piri, N. The effect of celastrol on the ocular hypertension-induced degeneration of retinal ganglion cells. Neurosci. Lett. 2018, 670, 89-93. [CrossRef]

158. Rasool, A.; Imran Mir, M.; Zulfajri, M.; Hanafiah, M.M.; Azeem Unnisa, S.; Mahboob, M. Plant growth promoting and antifungal asset of indigenous rhizobacteria secluded from saffron (Crocus sativus L.) rhizosphere. Microb. Pathog. 2021, 150, 104734. [CrossRef] [PubMed]

159. Fernandez-Albarral, J.A.; Ramirez, A.I.; de Hoz, R.; Lopez-Villarin, N.; Salobrar-Garcia, E.; Lopez-Cuenca, I.; Licastro, E.; Inarejos-Garcia, A.M.; Almodovar, P.; Pinazo-Duran, M.D.; et al. Neuroprotective and anti-inflammatory effects of a hydrophilic saffron extract in a model of glaucoma. Int. J. Mol. Sci. 2019, 20, 4110. [CrossRef]

160. Jabbarpoor Bonyadi, M.H.; Yazdani, S.; Saadat, S. The ocular hypotensive effect of saffron extract in primary open angle glaucoma: A pilot study. BMC Complement. Altern. Med. 2014, 14, 399. [CrossRef]

161. Maggi, M.A.; Bisti, S.; Picco, C. Saffron: Chemical composition and neuroprotective activity. Molecules 2020, 25, 5618. [CrossRef]

162. Chen, L.; Qi, Y.; Yang, X. Neuroprotective effects of crocin against oxidative stress induced by ischemia/reperfusion injury in rat retina. Ophthalmic Res. 2015, 54, 157-168. [CrossRef]

163. Qi, Y.; Chen, L.; Zhang, L.; Liu, W.B.; Chen, X.Y.; Yang, X.G. Crocin prevents retinal ischaemia/reperfusion injury-induced apoptosis in retinal ganglion cells through the PI3K/AKT signalling pathway. Exp. Eye Res. 2013, 107, 44-51. [CrossRef] [PubMed]

164. Lv, B.; Chen, T.; Xu, Z.; Huo, F.; Wei, Y.; Yang, X. Crocin protects retinal ganglion cells against $\mathrm{H}_{2} \mathrm{O}_{2}$-induced damage through the mitochondrial pathway and activation of NF-кB. Int. J. Mol. Med. 2016, 37, 225-232. [CrossRef]

165. Ohno, Y.; Nakanishi, T.; Umigai, N.; Tsuruma, K.; Shimazawa, M.; Hara, H. Oral administration of crocetin prevents inner retinal damage induced by N-methyl-D-aspartate in mice. Eur. J. Pharmacol. 2012, 690, 84-89. [CrossRef]

166. Ishizuka, F.; Shimazawa, M.; Umigai, N.; Ogishima, H.; Nakamura, S.; Tsuruma, K.; Hara, H. Crocetin, a carotenoid derivative, inhibits retinal ischemic damage in mice. Eur. J. Pharmacol. 2013, 703, 1-10. [CrossRef]

167. Kevin, T.T.M.; Nur Idanis, A.S.; Anastasha, B.; Mohd Faris, M.R.; Faizah, O.; Taty Anna, K. Curcumin minimises histopathological and immunological progression in the ankle joints of collagen-induced arthritis rats. Med. Health 2020, 15, 26-36. [CrossRef]

168. Kamal, D.A.M.; Salamt, N.; Yusuf, A.N.M.; Kashim, M.; Mokhtar, M.H. Potential health benefits of curcumin on female reproductive disorders: A review. Nutrients 2021, 13, 3126. [CrossRef]

169. Yue, Y.K.; Mo, B.; Zhao, J.; Yu, Y.J.; Liu, L.; Yue, C.L.; Liu, W. Neuroprotective effect of curcumin against oxidative damage in BV-2 microglia and high intraocular pressure animal model. J. Ocul. Pharmacol. Ther. 2014, 30, 657-664. [CrossRef]

170. Buccarello, L.; Dragotto, J.; Hassanzadeh, K.; Maccarone, R.; Corbo, M.; Feligioni, M. Retinal ganglion cell loss in an ex vivo mouse model of optic nerve cut is prevented by curcumin treatment. Cell Death Discov. 2021, 7, 394. [CrossRef]

171. Esfandiari, A.; Hashemi, F. Protective effects of curcumin on ischemic reperfusion of rat retina. Comp. Clin. Pathol. 2019, 28, 89-95. [CrossRef]

172. Wang, L.; Li, C.; Guo, H.; Kern, T.S.; Huang, K.; Zheng, L. Curcumin inhibits neuronal and vascular degeneration in retina after ischemia and reperfusion injury. PLoS ONE 2011, 6, e23194. [CrossRef] [PubMed]

173. Lin, C.; Wu, X. Curcumin protects trabecular meshwork cells from oxidative stress. Investig. Ophthalmol. Vis. Sci. 2016, 57, 4327-4332. [CrossRef] [PubMed]

174. Luo, Y.; Ding, H.; Li, D.; Luo, J. Curcumin protects trabecular meshwork cells against hydrogen peroxide-induced oxidative stress and apoptosis via Nrf2-keap1 pathway. Trop. J. Pharm. Res. 2018, 17, 2169-2176. [CrossRef]

175. Azmi, N.; Chee, S.H.; Mohd Fauzi, N.; Jasamai, M.; Kumolosasi, E. Viability and apoptotic effects of green tea (Camellia sinensis) methanol extract on human leukemic cell lines. Acta Pol. Pharm. Drug Res. 2018, 75, 51-58.

176. Yang, Y.; Xu, C.; Chen, Y.; Liang, J.J.; Xu, Y.; Chen, S.L.; Huang, S.; Yang, Q.; Cen, L.P.; Pang, C.P.; et al. Green tea extract ameliorates ischemia-induced retinal ganglion cell degeneration in rats. Oxidative Med. Cell. Longev. 2019, 2019, 8407206. [CrossRef]

177. Ren, J.L.; Yu, Q.X.; Liang, W.C.; Leung, P.Y.; Ng, T.K.; Chu, W.K.; Pang, C.P.; Chan, S.O. Green tea extract attenuates LPS-induced retinal inflammation in rats. Sci. Rep. 2018, 8, 429. [CrossRef]

178. Omar, M.S.; Adnan, N.N.; Kumolosasi, E.; Azmi, N.; Damanhuri, N.S.; Buang, F. Green tea (Camellia sinensis) extract reduces peptic ulcer induced by Helicobacter pylori in Sprague Dawley rats. Sains Malays. 2020, 49, 2793-2800. [CrossRef]

179. Zhang, W.H.; Chen, Y.; Gao, L.M.; Cao, Y.N. Neuroprotective role of epigallocatechin-3-gallate in acute glaucoma via the nuclear factor-kB signalling pathway. Exp. Ther. Med. 2021, 22, 1235. [CrossRef] [PubMed]

180. Shen, C.; Chen, L.; Jiang, L.; Lai, T.Y. Neuroprotective effect of epigallocatechin-3-gallate in a mouse model of chronic glaucoma. Neurosci. Lett. 2015, 600, 132-136. [CrossRef]

181. Xie, J.; Jiang, L.; Zhang, T.; Jin, Y.; Yang, D.; Chen, F. Neuroprotective effects of Epigallocatechin-3-gallate (EGCG) in optic nerve crush model in rats. Neurosci. Lett. 2010, 479, 26-30. [CrossRef]

182. Rivera-Perez, J.; Martinez-Rosas, M.; Conde-Castanon, C.A.; Toscano-Garibay, J.D.; Ruiz-Perez, N.J.; Flores, P.L.; Mera Jimenez, E.; Flores-Estrada, J. Epigallocatechin 3-Gallate has a neuroprotective effect in retinas of rabbits with ischemia/reperfusion through the activation of Nrf2/HO-1. Int. J. Mol. Sci. 2020, 21, 3716. [CrossRef]

183. Chen, F.; Jiang, L.; Shen, C.; Wan, H.; Xu, L.; Wang, N.; Jonas, J.B. Neuroprotective effect of epigallocatechin-3-gallate against N-methyl-D-aspartate-induced excitotoxicity in the adult rat retina. Acta Ophthalmol. 2012, 90, e609-e615. [CrossRef] 
184. Patel, S.; Rauf, A. Adaptogenic herb ginseng (Panax) as medical food: Status quo and future prospects. Biomed. Pharmacother. 2017, 85, 120-127. [CrossRef]

185. Kang, J.Y.; Kim, D.Y.; Lee, J.S.; Hwang, S.J.; Kim, G.H.; Hyun, S.H.; Son, C.G. Korean red ginseng ameliorates fatigue via modulation of 5-HT and corticosterone in a sleep-deprived mouse model. Nutrients 2021, 13, 3121. [CrossRef] [PubMed]

186. Lee, K.; Yang, H.; Kim, J.Y.; Choi, W.; Seong, G.J.; Kim, C.Y.; Lee, J.M.; Bae, H.W. Effect of red ginseng on visual function and vision-related quality of life in patients with glaucoma. J. Ginseng Res. 2021, 45, 676-682. [CrossRef]

187. Bae, H.W.; Kim, J.H.; Kim, S.; Kim, M.; Lee, N.; Hong, S.; Seong, G.J.; Kim, C.Y. Effect of Korean red ginseng supplementation on dry eye syndrome in glaucoma patients-A randomized, double-blind, placebo-controlled study. J. Ginseng Res. 2015, 39, 7-13. [CrossRef]

188. Kim, N.R.; Kim, J.H.; Kim, C.Y. Effect of Korean red ginseng supplementation on ocular blood flow in patients with glaucoma. J. Ginseng Res. 2010, 34, 237-245. [CrossRef]

189. Mathiyalagan, R.; Yang, D.C. Ginseng nanoparticles: A budding tool for cancer treatment. Nanomedicine 2017, 12, 1091-1094. [CrossRef]

190. Zhong, H.; Yu, H.; Chen, B.; Guo, L.; Xu, X.; Jiang, M.; Zhong, Y.; Qi, J.; Huang, P. Protective effect of total Panax notoginseng saponins on retinal ganglion cells of an optic nerve crush injury rat model. Biomed Res. Int. 2021, 2021, 4356949. [CrossRef]

191. Wang, L.; Cao, T.; Chen, H. Treatment of glaucomatous optic nerve damage using ginsenoside Rg1 mediated by ultrasound targeted microbubble destruction. Exp. Ther. Med. 2018, 15, 300-304. [CrossRef] [PubMed]

192. Liu, Z.; Chen, J.; Huang, W.; Zeng, Z.; Yang, Y.; Zhu, B. Ginsenoside Rb1 protects rat retinal ganglion cells against hypoxia and oxidative stress. Mol. Med. Rep. 2013, 8, 1397-1403. [CrossRef] [PubMed]

193. O'Neill-Dee, C.; Spiller, H.A.; Casavant, M.J.; Kistamgari, S.; Chounthirath, T.; Smith, G.A. Natural psychoactive substance-related exposures reported to United States poison control centers, 2000-2017. Clin. Toxicol. 2019, 58, 813-820. [CrossRef]

194. Katz, J.; Costarides, A.P. Facts vs fiction: The role of cannabinoids in the treatment of glaucoma. Curr. Ophthalmol. Rep. 2019, 7, 177-181. [CrossRef]

195. Merritt, J.C.; Crawford, W.J.; Alexander, P.C.; Anduze, A.L.; Gelbart, S.S. Effect of marihuana on intraocular and blood pressure in glaucoma. Ophthalmology 1980, 87, 222-228. [CrossRef]

196. Mosaed, S.; Liu, J.H.K.; Minckler, D.S.; Fitzgerald, R.L.; Grelotti, D.; Sones, E.; Sheils, C.R.; Weinreb, R.N.; Marcotte, T.D. The effect of inhaled cannabis on intraocular pressure in healthy adult subjects. Ophthalmology 2021, 15, 33-37. [CrossRef]

197. Fischer, K.M.; Ward, D.A.; Hendrix, D.V. Effects of a topically applied 2\% delta-9-tetrahydrocannabinol ophthalmic solution on intraocular pressure and aqueous humor flow rate in clinically normal dogs. Am. J. Vet. Res. 2013, 74, 275-280. [CrossRef] [PubMed]

198. Sweeney, C.; Dudhipala, N.; Thakkar, R.; Mehraj, T.; Marathe, S.; Gul, W.; ElSohly, M.A.; Murphy, B.; Majumdar, S. Effect of surfactant concentration and sterilization process on intraocular pressure-lowering activity of Delta(9)-tetrahydrocannabinolvaline-hemisuccinate (NB1111) nanoemulsions. Drug Deliv. Transl. Res. 2021, 11, 2096-2107. [CrossRef] [PubMed]

199. Muchtar, S.; Almog, S.; Torracca, M.T.; Saettone, M.F.; Benita, S. A submicron emulsion as ocular vehicle for delta-8tetrahydrocannabinol: Effect on intraocular pressure in rabbits. Ophthalmic Res. 1992, 24, 142-149. [CrossRef]

200. Song, Z.H.; Slowey, C.A. Involvement of cannabinoid receptors in the intraocular pressure-lowering effects of WIN55212-2. J. Pharmacol. Exp. Ther. 2000, 292, 136-139.

201. Pinar-Sueiro, S.; Zorrilla Hurtado, J.A.; Veiga-Crespo, P.; Sharma, S.C.; Vecino, E. Neuroprotective effects of topical CB1 agonist WIN 55212-2 on retinal ganglion cells after acute rise in intraocular pressure induced ischemia in rat. Exp. Eye Res. 2013, 110, 55-58. [CrossRef]

202. Khoo, H.E.; Azlan, A.; Tang, S.T.; Lim, S.M. Anthocyanidins and anthocyanins: Colored pigments as food, pharmaceutical ingredients, and the potential health benefits. Food Nutr. Res. 2017, 61, 1361779. [CrossRef]

203. Eng Khoo, H.; Meng Lim, S.; Azlan, A. Evidence-Based Therapeutic Effects of Anthocyanins from Foods. Pak. J. Nutr. 2018, 18, 1-11. [CrossRef]

204. Ohguro, H.; Ohguro, I.; Katai, M.; Tanaka, S. Two-year randomized, placebo-controlled study of black currant anthocyanins on visual field in glaucoma. Ophthalmologica 2012, 228, 26-35. [CrossRef] [PubMed]

205. Ohguro, H.; Ohguro, I.; Yagi, S. Effects of black currant anthocyanins on intraocular pressure in healthy volunteers and patients with glaucoma. J. Ocul. Pharmacol. Ther. 2013, 29, 61-67. [CrossRef]

206. Yoshida, K.; Ohguro, I.; Ohguro, H. Black currant anthocyanins normalized abnormal levels of serum concentrations of endothelin1 in patients with glaucoma. J. Ocul. Pharmacol. Ther. 2013, 29, 480-487. [CrossRef] [PubMed]

207. Chuang, L.H.; Wu, A.L.; Wang, N.K.; Chen, K.J.; Liu, L.; Hwang, Y.S.; Yeung, L.; Wu, W.C.; Lai, C.C. The intraocular staining potential of anthocyanins and their retinal biocompatibility: A preclinical study. Cutan. Ocul. Toxicol. 2018, 37, 359-366. [CrossRef] [PubMed]

208. Nakamura, O.; Moritoh, S.; Sato, K.; Maekawa, S.; Murayama, N.; Himori, N.; Omodaka, K.; Sogon, T.; Nakazawa, T. Bilberry extract administration prevents retinal ganglion cell death in mice via the regulation of chaperone molecules under conditions of endoplasmic reticulum stress. Clin. Ophthalmol. 2017, 11, 1825-1834. [CrossRef] [PubMed]

209. Wang, Y.; Zhao, L.; Lu, F.; Yang, X.; Deng, Q.; Ji, B.; Huang, F. Retinoprotective effects of bilberry anthocyanins via antioxidant, anti-inflammatory, and anti-apoptotic mechanisms in a visible light-induced retinal degeneration model in pigmented rabbits. Molecules 2015, 20, 22395-22410. [CrossRef] [PubMed] 
210. Ramalingam, A.; Santhanathas, T.; Shaukat Ali, S.; Zainalabidin, S. Resveratrol supplementation protects against nicotine-induced kidney injury. Int. J. Environ. Res Public Health 2019, 16, 4445. [CrossRef]

211. Avotri, S.; Eatman, D.; Russell-Randall, K. Effects of Resveratrol on inflammatory biomarkers in glaucomatous human trabecular meshwork cells. Nutrients 2019, 11, 984. [CrossRef]

212. Pirhan, D.; Yuksel, N.; Emre, E.; Cengiz, A.; Kursat Yildiz, D. Riluzole- and resveratrol-induced delay of retinal ganglion cell death in an experimental model of glaucoma. Curr. Eye Res. 2016, 41, 59-69. [CrossRef]

213. Cao, K.; Ishida, T.; Fang, Y.; Shinohara, K.; Li, X.; Nagaoka, N.; Ohno-Matsui, K.; Yoshida, T. Protection of the retinal ganglion cells: Intravitreal injection of resveratrol in mouse model of ocular hypertension. Investig. Ophthalmol. Vis. Sci. 2020, 61, 13. [CrossRef]

214. Ye, M.J.; Meng, N. Resveratrol acts via the mitogen-activated protein kinase (MAPK) pathway to protect retinal ganglion cells from apoptosis induced by hydrogen peroxide. Bioengineered 2021, 12, 4878-4886. [CrossRef]

215. Ji, K.; Li, Z.; Lei, Y.; Xu, W.; Ouyang, L.; He, T.; Xing, Y. Resveratrol attenuates retinal ganglion cell loss in a mouse model of retinal ischemia reperfusion injury via multiple pathways. Exp. Eye Res. 2021, 209, 108683. [CrossRef]

216. Luo, H.; Zhuang, J.; Hu, P.; Ye, W.; Chen, S.; Pang, Y.; Li, N.; Deng, C.; Zhang, X. Resveratrol delays retinal ganglion cell loss and attenuates gliosis-related inflammation from ischemia-reperfusion injury. Investig. Ophthalmol. Vis. Sci. 2018, 59, 3879-3888. [CrossRef]

217. Xia, J.; Yang, X.; Chen, W. Resveratrol protects the retina from I/R injury by inhibiting RGCS apoptosis, glial activation and expression of inflammatory factors. Trop. J. Pharm. Res. 2020, 19, 1221-1226. [CrossRef]

218. Zhang, X.; Feng, Y.; Wang, Y.; Wang, J.; Xiang, D.; Niu, W.; Yuan, F. Resveratrol ameliorates disorders of mitochondrial biogenesis and dynamics in a rat chronic ocular hypertension model. Life Sci. 2018, 207, 234-245. [CrossRef] [PubMed]

219. Pang, Y.; Qin, M.; Hu, P.; Ji, K.; Xiao, R.; Sun, N.; Pan, X.; Zhang, X. Resveratrol protects retinal ganglion cells against ischemia induced damage by increasing Opa1 expression. Int. J. Mol. Med. 2020, 46, 1707-1720. [CrossRef] [PubMed]

220. Means, J.C.; Lopez, A.A.; Koulen, P. Resveratrol protects optic nerve head astrocytes from oxidative stress-induced cell death by preventing caspase-3 activation, tau dephosphorylation at Ser(422) and formation of misfolded protein aggregates. Cell. Mol. Neurobiol. 2020, 40, 911-926. [CrossRef]

221. Gandhi, G.R.; Vasconcelos, A.B.S.; Wu, D.T.; Li, H.B.; Antony, P.J.; Li, H.; Geng, F.; Gurgel, R.Q.; Narain, N.; Gan, R.Y. Citrus flavonoids as promising phytochemicals targeting diabetes and related complications: A systematic review of in vitro and in vivo studies. Nutrients 2020, 12, 2907. [CrossRef]

222. Himori, N.; Inoue Yanagimachi, M.; Omodaka, K.; Shiga, Y.; Tsuda, S.; Kunikata, H.; Nakazawa, T. The effect of dietary antioxidant supplementation in patients with glaucoma. Clin. Ophthalmol. 2021, 15, 2293-2300. [CrossRef] [PubMed]

223. Lu, B.; Wang, X.; Ren, Z.; Jiang, H.; Liu, B. Anti-glaucoma potential of hesperidin in experimental glaucoma induced rats. $A M B$ Express 2020, 10, 94. [CrossRef]

224. Sato, K.; Sato, T.; Ohno-Oishi, M.; Ozawa, M.; Maekawa, S.; Shiga, Y.; Yabana, T.; Yasuda, M.; Himori, N.; Omodaka, K.; et al. $\mathrm{CHOP}$ deletion and anti-neuroinflammation treatment with hesperidin synergistically attenuate NMDA retinal injury in mice. Exp. Eye Res. 2021, 213, 108826. [CrossRef]

225. Maekawa, S.; Sato, K.; Fujita, K.; Daigaku, R.; Tawarayama, H.; Murayama, N.; Moritoh, S.; Yabana, T.; Shiga, Y.; Omodaka, K.; et al. The neuroprotective effect of hesperidin in NMDA-induced retinal injury acts by suppressing oxidative stress and excessive calpain activation. Sci. Rep. 2017, 7, 6885. [CrossRef]

226. Xin, X.; Li, Y.; Liu, H. Hesperidin ameliorates hypobaric hypoxia-induced retinal impairment through activation of Nrf2/HO-1 pathway and inhibition of apoptosis. Sci. Rep. 2020, 10, 19426. [CrossRef] [PubMed]

227. Md Isa, Z.; Anuar, A.A.; Danial Azmi, A.; Selvan, S.T.; Hisham, N.S.; Yong, Z.Q. Does caffeine intake influence mental health of medical students? Malays. J. Public Health Med. 2021, 21, 22-28. [CrossRef]

228. Tran, T.; Niyadurupola, N.; O'Connor, J.; Ang, G.S.; Crowston, J.; Nguyen, D. Rise of intraocular pressure in a caffeine test versus the water drinking test in patients with glaucoma. Clin. Exp. Ophthalmol. 2014, 42, 427-432. [CrossRef] [PubMed]

229. Chandra, P.; Gaur, A.; Varma, S. Effect of caffeine on the intraocular pressure in patients with primary open angle glaucoma. Clin. Ophthalmol. 2011, 5, 1623-1629. [CrossRef]

230. Vera, J.; Redondo, B.; Molina, R.; Bermudez, J.; Jimenez, R. Effects of caffeine on intraocular pressure are subject to tolerance: A comparative study between low and high caffeine consumers. Psychopharmacology 2019, 236, 811-819. [CrossRef] [PubMed]

231. Redondo, B.; Vera, J.; Molina, R.; Jimenez, R. Short-term effects of caffeine intake on anterior chamber angle and intraocular pressure in low caffeine consumers. Graefes Arch. Clin. Exp. Ophthalmol. 2020, 258, 613-619. [CrossRef] [PubMed]

232. Kim, J.; Aschard, H.; Kang, J.H.; Lentjes, M.A.H.; Do, R.; Wiggs, J.L.; Khawaja, A.P.; Pasquale, L.R.; Modifiable Risk Factors for Glaucoma Collaboration. Intraocular pressure, glaucoma, and dietary caffeine consumption: A gene-diet interaction study from the UK Biobank. Ophthalmology 2021, 128, 866-876. [CrossRef]

233. Nakano, E.; Miyake, M.; Hosoda, Y.; Mori, Y.; Suda, K.; Kameda, T.; Ikeda-Ohashi, H.; Tabara, Y.; Yamashiro, K.; Tamura, H.; et al. Relationship between intraocular pressure and coffee consumption in a Japanese population without glaucoma: The Nagahama study. Ophthalmol. Glaucoma 2021, 4, 268-276. [CrossRef]

234. Madeira, M.H.; Ortin-Martinez, A.; Nadal-Nicolas, F.; Ambrosio, A.F.; Vidal-Sanz, M.; Agudo-Barriuso, M.; Santiago, A.R. Caffeine administration prevents retinal neuroinflammation and loss of retinal ganglion cells in an animal model of glaucoma. Sci. Rep. 2016, 6, 27532. [CrossRef] 
235. Boia, R.; Elvas, F.; Madeira, M.H.; Aires, I.D.; Rodrigues-Neves, A.C.; Tralhao, P.; Szabo, E.C.; Baqi, Y.; Muller, C.E.; Tome, A.R.; et al. Treatment with $\mathrm{A}_{2 \mathrm{~A}}$ receptor antagonist KW6002 and caffeine intake regulate microglia reactivity and protect retina against transient ischemic damage. Cell Death Dis. 2017, 8, e3065. [CrossRef]

236. Conti, F.; Lazzara, F.; Romano, G.L.; Platania, C.B.M.; Drago, F.; Bucolo, C. Caffeine protects against retinal inflammation. Front. Pharmacol. 2022, 12, 824885. [CrossRef]

237. Zulfakar, M.H.; Chan, L.M.; Rehman, K.; Wai, L.K.; Heard, C.M. Coenzyme Q10-loaded fish oil-based bigel system: Probing the delivery across porcine skin and possible interaction with fish oil fatty acids. AAPS PharmSciTech. 2018, 19, 1116-1123. [CrossRef] [PubMed]

238. Ekeuku, S.O.; Ima-Nirwana, S.; Chin, K.Y. Skeletal protective effect of Coenzyme Q10: A review. Int. J. Pharmacol. 2020, 16, 181-190. [CrossRef]

239. Lee, D.; Kim, K.Y.; Shim, M.S.; Kim, S.Y.; Ellisman, M.H.; Weinreb, R.N.; Ju, W.K. Coenzyme Q10 ameliorates oxidative stress and prevents mitochondrial alteration in ischemic retinal injury. Apoptosis 2014, 19, 603-614. [CrossRef]

240. Lee, D.; Shim, M.S.; Kim, K.Y.; Noh, Y.H.; Kim, H.; Kim, S.Y.; Weinreb, R.N.; Ju, W.K. Coenzyme Q10 inhibits glutamate excitotoxicity and oxidative stress-mediated mitochondrial alteration in a mouse model of glaucoma. Investig. Ophthalmol. Vis. Sci. 2014, 55, 993-1005. [CrossRef] [PubMed]

241. Davis, B.M.; Tian, K.; Pahlitzsch, M.; Brenton, J.; Ravindran, N.; Butt, G.; Malaguarnera, G.; Normando, E.M.; Guo, L.; Cordeiro, M.F. Topical Coenzyme Q10 demonstrates mitochondrial-mediated neuroprotection in a rodent model of ocular hypertension. Mitochondrion 2017, 36, 114-123. [CrossRef]

242. Parisi, V.; Centofanti, M.; Gandolfi, S.; Marangoni, D.; Rossetti, L.; Tanga, L.; Tardini, M.; Traina, S.; Ungaro, N.; Vetrugno, M.; et al Effects of coenzyme Q10 in conjunction with vitamin E on retinal-evoked and cortical-evoked responses in patients with open-angle glaucoma. J. Glaucoma 2014, 23, 391-404. [CrossRef] [PubMed]

243. Ekicier Acar, S.; Saricaoglu, M.S.; Colak, A.; Aktas, Z.; Sepici Dincel, A. Neuroprotective effects of topical coenzyme Q10 + vitamin E in mechanic optic nerve injury model. Eur. J. Ophthalmol. 2020, 30, 714-722. [CrossRef]

244. Wang, S.Y.; Singh, K.; Lin, S.C. Glaucoma and vitamins A, C, and E supplement intake and serum levels in a population-based sample of the United States. Eye 2013, 27, 487-494. [CrossRef]

245. Li, S.; Li, D.; Shao, M.; Cao, W.; Sun, X. Lack of association between serum vitamin $B_{6}$, vitamin $B_{12}$, and vitamin D levels with different types of glaucoma: A systematic review and meta-analysis. Nutrients 2017, 9, 636. [CrossRef]

246. Ramdas, W.D.; Schouten, J.; Webers, C.A.B. The effect of vitamins on glaucoma: A systematic review and meta-analysis. Nutrients 2018, 10, 359. [CrossRef] [PubMed]

247. Williams, P.A.; Harder, J.M.; Foxworth, N.E.; Cochran, K.E.; Philip, V.M.; Porciatti, V.; Smithies, O.; John, S.W. Vitamin B 3 modulates mitochondrial vulnerability and prevents glaucoma in aged mice. Science 2017, 355, 756-760. [CrossRef] [PubMed]

248. Chou, T.H.; Romano, G.L.; Amato, R.; Porciatti, V. Nicotinamide-rich diet in DBA/2J mice preserves retinal ganglion cell metabolic function as assessed by PERG adaptation to flicker. Nutrients 2020, 12, 1910. [CrossRef]

249. Hui, F.; Tang, J.; Williams, P.A.; McGuinness, M.B.; Hadoux, X.; Casson, R.J.; Coote, M.; Trounce, I.A.; Martin, K.R.; van Wijngaarden, P.; et al. Improvement in inner retinal function in glaucoma with nicotinamide (vitamin $B_{3}$ ) supplementation: A crossover randomized clinical trial. Clin. Exp. Ophthalmol. 2020, 48, 903-914. [CrossRef]

250. Vukovic Arar, Z.; Knezevic Pravecek, M.; Miskic, B.; Vatavuk, Z.; Vukovic Rodriguez, J.; Sekelj, S. Association between serum vitamin D level and glaucoma in women. Acta Clin. Croat. 2016, 55, 203-208. [CrossRef] [PubMed]

251. Lv, Y.; Yao, Q.; Ma, W.; Liu, H.; Ji, J.; Li, X. Associations of vitamin D deficiency and vitamin D receptor (Cdx-2, Fok I, Bsm I and Taq I) polymorphisms with the risk of primary open-angle glaucoma. BMC Ophthalmol. 2016, 16, 116. [CrossRef]

252. Kocaturk, T.; Bekmez, S.; Unubol, M. Effects of vitamin D deficiency on intraocular pressure values obtained by ocular response analyzer. Int. Ophthalmol. 2020, 40, 697-701. [CrossRef]

253. Kutuzova, G.D.; Gabelt, B.T.; Kiland, J.A.; Hennes-Beann, E.A.; Kaufman, P.L.; DeLuca, H.F. $1 \alpha, 25-D i h y d r o x y v i t a m i n ~ D_{3}$ and its analog, 2-methylene-19-nor-(20S)-1 $\alpha$,25-dihydroxyvitamin $\mathrm{D}_{3}$ (2MD), suppress intraocular pressure in non-human primates. Arch. Biochem. Biophys. 2012, 518, 53-60. [CrossRef]

254. Lazzara, F.; Amato, R.; Platania, C.B.M.; Conti, F.; Chou, T.H.; Porciatti, V.; Drago, F.; Bucolo, C. 1 $\alpha, 25-$ dihydroxyvitamin D 3 protects retinal ganglion cells in glaucomatous mice. J. Neuroinflamm. 2021, 18, 206. [CrossRef]

255. Ko, M.L.; Peng, P.H.; Hsu, S.Y.; Chen, C.F. Dietary deficiency of vitamin E aggravates retinal ganglion cell death in experimental glaucoma of rats. Curr. Eye Res. 2010, 35, 842-849. [CrossRef]

256. Özmen, C.; Göçün, P.; Değim, Z.; Özkan, Y.; Onol, M.; Aktaş, Z. Retinal ganglion cell protection via topical and systemic alpha-tocopherol administration in optic nerve crush model of rat. Turk. J. Ophthalmol. 2013, 43, 161-166. [CrossRef]

257. Yellanki, S.K.; Anna, B.; Kishan, M.R. Preparation and in vivo evaluation of sodium alginate-poly (vinyl alcohol) electrospun nanofibers of forskolin for glaucoma treatment. Pak. J. Pharm. Sci. 2019, 32, 669-674. [PubMed]

258. Davis, B.M.; Pahlitzsch, M.; Guo, L.; Balendra, S.; Shah, P.; Ravindran, N.; Malaguarnera, G.; Sisa, C.; Shamsher, E.; Hamze, H.; et al. Topical curcumin nanocarriers are neuroprotective in eye disease. Sci. Rep. 2018, 8, 11066. [CrossRef] [PubMed]

259. Cheng, Y.H.; Ko, Y.C.; Chang, Y.F.; Huang, S.H.; Liu, C.J. Thermosensitive chitosan-gelatin-based hydrogel containing curcuminloaded nanoparticles and latanoprost as a dual-drug delivery system for glaucoma treatment. Exp. Eye Res. 2019, 179, 179-187. [CrossRef] [PubMed] 
260. Natesan, S.; Pandian, S.; Ponnusamy, C.; Palanichamy, R.; Muthusamy, S.; Kandasamy, R. Co-encapsulated resveratrol and quercetin in chitosan and peg modified chitosan nanoparticles: For efficient intra ocular pressure reduction. Int. J. Biol. Macromol. 2017, 104, 1837-1845. [CrossRef] [PubMed]

261. World Health Organization. Research Guidelines for Evaluating the Safety and Efficacy of Herbal Medicines; World Health Organization: Geneva, Switzerland, 1993; p. 89.

262. Suntar, I. Importance of ethnopharmacological studies in drug discovery: Role of medicinal plants. Phytochem. Rev. 2020, 19, 1199-1209. [CrossRef]

263. Vetrugno, M.; Uva, M.G.; Russo, V.; Iester, M.; Ciancaglini, M.; Brusini, P.; Centofanti, M.; Rossetti, L.M. Oral administration of forskolin and rutin contributes to intraocular pressure control in primary open angle glaucoma patients under maximum tolerated medical therapy. J. Ocul. Pharmacol. Ther. 2012, 28, 536-541. [CrossRef]

264. Nebbioso, M.; Rusciano, D.; Pucci, B.; Zicari, A.M.; Grenga, R.; Pescocolido, N. Treatment of glaucomatous patients by means of food supplement to reduce the ocular discomfort: A double blind randomized trial. Eur. Rev. Med. Pharmacol. Sci. 2013, 17, 1117-1122.

265. Nebbioso, M.; Belcaro, G.; Librando, A.; Rusciano, D.; Steigerwalt, R.D., Jr.; Pescosolido, N. Forskolin and rutin prevent intraocular pressure spikes after Nd:YAG laser iridotomy. Panminerva Med. 2012, 54, 77-82.

266. Mutolo, M.G.; Albanese, G.; Rusciano, D.; Pescosolido, N. Oral Administration of forskolin, homotaurine, carnosine, and folic acid in patients with primary open angle glaucoma: Changes in intraocular pressure, pattern electroretinogram amplitude, and foveal sensitivity. J. Ocul. Pharmacol. Ther. 2016, 32, 178-183. [CrossRef]

267. Rolle, T.; Dallorto, L.; Rossatto, S.; Curto, D.; Nuzzi, R. Assessing the Performance of daily intake of a homotaurine, carnosine, forskolin, vitamin B2, vitamin B6, and magnesium based food supplement for the maintenance of visual function in patients with primary open angle glaucoma. J. Ophthalmol. 2020, 2020, 7879436. [CrossRef] [PubMed]

268. Manabe, K.; Kaidzu, S.; Tsutsui, A.; Mochiji, M.; Matsuoka, Y.; Takagi, Y.; Miyamoto, E.; Tanito, M. Effects of French maritime pine bark/bilberry fruit extracts on intraocular pressure for primary open-angle glaucoma. J. Clin. Biochem. Nutr. 2021, 68, 67-72. [CrossRef]

269. Yadav, K.S.; Rajpurohit, R.; Sharma, S. Glaucoma: Current treatment and impact of advanced drug delivery systems. Life Sci. 2019, 221, 362-376. [CrossRef]

270. Gupta, R.; Patil, B.; Shah, B.M.; Bali, S.J.; Mishra, S.K.; Dada, T. Evaluating eye drop instillation technique in glaucoma patients. J. Glaucoma 2012, 21, 189-192. [CrossRef] [PubMed]

271. Rahic, O.; Tucak, A.; Omerovic, N.; Sirbubalo, M.; Hindija, L.; Hadziabdic, J.; Vranic, E. Novel drug delivery systems fighting glaucoma: Formulation obstacles and solutions. Pharmaceutics 2020, 13, 28. [CrossRef] [PubMed]

272. Li, J.; Jin, X.; Yang, Y.; Zhang, L.; Liu, R.; Li, Z. Trimethyl chitosan nanoparticles for ocular baicalein delivery: Preparation, optimization, in vitro evaluation, in vivo pharmacokinetic study and molecular dynamics simulation. Int. J. Biol. Macromol. 2020, 156, 749-761. [CrossRef] [PubMed]

273. Hsu, Y.T.; Youle, R.J. Nonionic detergents induce dimerization among members of the Bcl-2 family. J. Biol. Chem. 1997, 272, 13829-13834. [CrossRef]

274. Hsu, Y.T.; Youle, R.J. Bax in murine thymus is a soluble monomeric protein that displays differential detergent-induced conformations. J. Biol. Chem. 1998, 273, 10777-10783. [CrossRef]

275. Levin, L.A.; Schlamp, C.L.; Spieldoch, R.L.; Geszvain, K.M.; Nickells, R.W. Identification of the bcl-2 family of genes in the rat retina. Investig. Ophthalmol. Vis. Sci. 1997, 38, 2545-2553.

276. Chen, S.T.; Garey, L.J.; Jen, L.S. Bcl-2 proto-oncogene protein immunoreactivity in normally developing and axotomised rat retinas. Neurosci. Lett. 1994, 172, 11-14. [CrossRef] 